\title{
Consensus Recommendations on GLP-1 RA Use in the Management of Type 2 Diabetes Mellitus: South Asian Task Force
}

\author{
Sanjay Kalra · Ashok Kumar Das · Rakesh Kumar Sahay • Manash Pratim Baruah • Mangesh Tiwaskar • \\ Sambit Das · Sudip Chatterjee - Banshi Saboo • Ganapathi Bantwal - Saptarshi Bhattacharya • \\ Gagan Priya · Manoj Chawla · Kiraninder Brar · Syed Abbas Raza • Azizul Hasan Aamir • \\ Dina Shrestha · Noel Somasundaram · Prasad Katulanda · Faria Afsana - Shahjada Selim • \\ Mohammad Wali Naseri · Ali Latheef · Manilka Sumanatilleke \\ Received: March 7, 2019 / Published online: July 29, 2019 \\ (C) The Author(s) 2019
}

\section{ABSTRACT}

The advent of incretin mimetics such as glucagon-like peptide-1 receptor agonists (GLP-1 RAs) has enriched the armamentarium for diabetes management owing to their glycaemic as well as extra-glycaemic benefits. The approval status and availability of this class of drugs vary widely

Enhanced Digital Features To view enhanced digital features for this article go to https://doi.org/10.6084/ m9.figshare. 8850866 .

Electronic Supplementary Material The online version of this article (https://doi.org/10.1007/s13300019-0669-4) contains supplementary material, which is available to authorized users.

S. Kalra $(\bowtie)$

Bharti Hospital, Karnal, India

e-mail: brideknl@gmail.com

A. K. Das

Pondicherry Institute of Medical Sciences,

Pondicherry, India

R. K. Sahay

Osmania Medical College, Hyderabad, India

M. P. Baruah

Excelcare Hospitals, Guwahati, India

M. Tiwaskar

Karuna Hospital, Mumbai, India

S. Das

Hi Tech Medical College and Hospital, Bhubaneshwar, India across the globe. Being a relatively newer class of drug with numerous benefits, several national and international guidelines are working towards addressing clinical questions pertaining to the optimal use of GLP-1 RAs for the management of diabetes. Although the newer class of drugs are associated with significant benefits such as patient-centric approach, these drugs demand the providers to be vigilant and knowledgeable about the medication. The South Asian population is at higher risk of type 2 diabetes mellitus (T2DM) because of their genetic predisposition and lifestyle changes. Hence, prevention and management of T2DM and its associated complications in this population are of paramount importance. The current report aims to present an overview of

\section{S. Chatterjee}

Park Clinic, Kolkata, India

B. Saboo

Dia Care, Ahmedabad, India

G. Bantwal

St John's Medical College, Bangalore, India

S. Bhattacharya

Max Super Speciality Hospital, Delhi, India

G. Priya

Fortis Hospital, Mohali, India

M. Chawla

BSES MG Hospital, Mumbai, India

K. Brar

Army Research and Referral Hospital, Delhi, India 
current knowledge on GLP-1 RAs based on pragmatic review of the available clinical evidence. In addition, this report is a consensus of expert endocrinologists representing South Asian countries including India, Pakistan, Bangladesh, Nepal, Sri Lanka, Afghanistan and the Maldives on essential recommendations related to the use of GLP-1 RAs in a real-world scenario.

Keywords: Calorie restriction mimetics; Calorie restriction facilitators; Consensus; GLP$1 \mathrm{RA}$; Incretin-based therapies; Type 2 diabetes mellitus

\section{EXECUTIVE SUMMARY}

The current report is an overview of current knowledge on glucagon-like peptide-1 receptor agonists (GLP-1 RAs) based on pragmatic review of the available clinical evidence on use of GLP1 RAs in the management of type 2 diabetes mellitus (T2DM). This report is also a consensus of an expert panel of endocrinologists representing South Asian countries on essential recommendations related to the use of GLP-1 RAs which may aid in rational, smart and safe prescription of GLP-1 RAs in a real-world scenario.

The current report discusses the mechanism of action, classification, pharmacokinetic and pharmacodynamic properties of various GLP-1 RAs. Further, an overview of the prescribing information and recommendations on GLP-1 RA use in T2DM management from diabetic associations across the world is presented.

S. A. Raza

Shaukat Khanum Memorial Cancer Hospital and

Research Centre and National Defence Hospital,

Lahore, Pakistan

A. H. Aamir

Hayatabad Medical Complex, Peshawar, Pakistan

D. Shrestha

Norvic International Hospital, Kathmandu, Nepal

N. Somasundaram · M. Sumanatilleke

National Hospital of Sri Lanka, Colombo, Sri Lanka

P. Katulanda

University of Colombo, Colombo, Sri Lanka
Clinical evidence (based on the literature) on GLP-1 RAs licensed in South Asia or under regulatory approval in one or more South Asian countries is presented and based on prescription pattern and the geography of the reported patient group. In an evidence-based approach, the key points contributing to this consensus with respect to the clinical impact and benefits of GLP-1 RAs and their use in special populations are as follows:

Clinical impact of GLP-1 RAs:

- GLP-1 RAs improve glucose homeostasis by enhancing glucose-dependent insulin secretion, by suppressing inappropriately elevated glucagon levels, both in fasting and postprandial states (Grade A; Evidence Level [EL] $1)$.

- GLP-1 RAs are associated with weight loss benefits which might be due to suppressed appetite, reduced body fat or improved endothelial function (Grade A; EL 1).

- GLP-1 RAs are known to have a beneficial effect on lipid profile and blood pressure (BP). In addition, GLP-1 RAs have demonstrated cardioprotective effects in patients with T2DM (Grade A; EL 1).

- GLP-1 RAs are known to have both direct and indirect renoprotective effects and are also associated with hepatic health benefits (Grade A; EL 1).

GLP-1 RA use in complicated diabetes:

- There is no clear evidence regarding the use of GLP-1 RA in acute myocardial infarction, although the use of these agents is encouraged in patients with asymptomatic and

F. Afsana

BIRDEM, Dhaka, Bangladesh

S. Selim

Bangabandhu Sheikh Mujib Medical University, Shahbag, Dhaka, Bangladesh

M. W. Naseri

Kabul University of Medical Science, Kabul, Afghanistan

A. Latheef

Department of Medicine, Indra Gandhi Hospital, Male, Maldives 
stable coronary artery disease (CAD). The use of GLP-1 analogues in such cases could be a pragmatic approach based on prescribing information, available clinical evidence and clinical sense of physicians (Grade D; EL 4)

- Exenatide and lixisenatide are predominantly cleared by the kidney. Exenatide dosage is not recommended to be increased in patients with an estimated glomerular filtration rate (eGFR) of $30-60 \mathrm{~mL} / \mathrm{min} /$ $1.73 \mathrm{~m}^{2}$. Both exenatide and lixisenatide are contraindicated in patients with eGFR $<30 \mathrm{~mL} / \mathrm{min} / 1.73 \mathrm{~m}^{2}$. Although clearance of liraglutide and dulaglutide is predominantly hepatic, administration of these drugs in patients with renal impairment needs to be considered with caution because of gastrointestinal side effects (Grade D; EL 4).

- There is limited information available on the safety and efficacy of GLP-1 RAs in patients with hepatic impairment. The prescribing information advises cautious use in this patient population (Grade D; EL 4).

GLP-1 RA use in special situations:

- GLP-1 RAs are known to have low risk of hypoglycaemia and offer least glycaemic variability which is suitable for the elderly population (Grade B; EL 2).

- GLP-1 RAs do not require dose adjustments during fasting including the period of Ramadan; however, dose adjustments for concomitant medications such as insulin may be required (Grade D; EL 4).

- GLP-1 RAs have expanded the treatment option for polycystic ovary syndrome owing to their ability to influence both body weight and glycaemic control (Grade A; EL 1).

- There is limited data on the use GLP-1 RAs in pregnant and lactating women (Grade D; EL 4).

Based on the experience, judgement and consensus of the expert panel of endocrinologists, essential information on GLP-1 RA therapy for healthcare practitioners in the form of checklists has been presented. The checklists include patient selection and rationale for GLP1 RA therapy initiation, factors influencing selection of appropriate GLP-1 RA, selection of appropriate GLP-1 RA and monitoring checklist specific for GLP-1 RA-based therapy. Cost implications, barriers to GLP-1 RA therapy and measures to mitigate the barriers have also been discussed.

\section{INTRODUCTION}

Type 2 diabetes mellitus (T2DM) is the most common type of diabetes, accounting for approximately $90 \%$ of all cases worldwide. The global prevalence of diabetes was estimated to be $8.8 \%$ (as of 2017) and is foreseen to rise to $9.9 \%$ by 2045 [1]. Among the ethnic groups, people of South Asian ancestry are four times more susceptible to T2DM compared to Europeans owing to their genetic predisposition [2]. In addition, lifestyle changes including those associated with urbanisation and migration play a major role in the rapid rise of diabetes in South Asia [3]. Notably, India and Pakistan are listed among the top 10 countries worldwide for the number of adults (age group 20-79 years) with diabetes [1]. The prevalence of diabetes and the mortality and expenditure associated with it in South Asia (as of 2017) are presented by country in Table 1 .

Obesity is identified as a major risk factor leading to diabetes, hypertension, dyslipidaemia, coronary heart disease and many types of cancers [5]. The mean prevalence of obesity in South Asia rose to $28.85 \%$ in 2013 from $23.62 \%$ in 1990 , drawing attention to the seriousness of this growing public health issue [6]. The thin-fat Indian concept or Asian Indian phenotype is characterised by less generalised obesity measured by body mass index (BMI) and greater central obesity associated with waist circumference and waist-hip ratio [7-9]. Higher prevalence of central obesity among South Asians is also considered to be an important risk factor for T2DM, metabolic syndrome (MetS) and cardiovascular disease (CVD) [10, 11]. Nutritional transition, urbanisation, physical inactivity, socio-economic factors, cultural factors and genetics are currently the determinants of obesity and dyslipidaemia in South Asians [10]. 
Table 1 Prevalence, mortality and expenditure associated with diabetes burden in South Asian countries. Adapted from IDF Diabetes Atlas, 8th Edition [4]

\begin{tabular}{|c|c|c|c|c|c|c|c|c|}
\hline Country & $\begin{array}{l}\text { Total adult } \\
\text { population }^{\text {a }}\end{array}$ & $\begin{array}{l}\text { Diabetes } \\
\text { cases }^{\text {a }}\end{array}$ & Ratio $^{\mathbf{a}, \mathbf{b}}$ & $\begin{array}{l}\text { Undiagnosed } \\
\text { diabetes } \\
\text { cases }^{\text {a }}\end{array}$ & $\begin{array}{l}\text { Diabetes } \\
\text { national } \\
\text { prevalence }^{\mathrm{a}} \\
(\%)\end{array}$ & $\begin{array}{l}\text { Diabetes } \\
\text { age-adjusted } \\
\text { comparative } \\
\text { prevalence } \\
\text { (\%) }\end{array}$ & $\begin{array}{l}\text { Diabetes- } \\
\text { related } \\
\text { death }^{\mathrm{a}}\end{array}$ & $\begin{array}{l}\text { Cost per } \\
\text { person } \\
\text { with } \\
\text { diabetes } \\
\text { (USD) }\end{array}$ \\
\hline Afghanistan & $17,150,814$ & $1,054,460$ & $1: 16$ & 733,870 & 6.1 & 9.2 & 20,960 & 114.67 \\
\hline Bangladesh & $108,274,040$ & $7,349,526$ & $1: 15$ & $4,115,734$ & 6.8 & 8.3 & 108,530 & 50.94 \\
\hline India & $892,039,240$ & $74,047,266$ & $1: 12$ & $42,847,334$ & 8.3 & 9.8 & $1,123,804$ & 120.07 \\
\hline Maldives & 254,702 & 18,996 & $1: 13$ & 10,319 & 7.5 & 8.9 & 128 & 1939.74 \\
\hline Nepal & $18,141,114$ & 679,207 & $1: 27$ & 549,934 & 3.7 & 7.1 & 13,431 & 74.18 \\
\hline Pakistan & $116,776,556$ & $7,656,317$ & $1: 15$ & $4,706,338$ & 6.6 & 8.0 & 89,285 & 63.23 \\
\hline Sri Lanka & $14,922,252$ & $1,248,310$ & $1: 12$ & 446,645 & 8.4 & 10.3 & 17,747 & 189.63 \\
\hline
\end{tabular}

${ }^{a}$ Age group 18-99 years

b Total number of diabetes cases: total adult population

The term diabesity, first coined in 1970, has been used to describe the strong association between diabetes and obesity when they coexist in an individual $[12,13]$. At least $80-90 \%$ of T2DM patients are reported to be obese $[14,15]$. Diabesity is expected to be one of the biggest epidemics in human history. Intriguingly, there are no guidelines from associations worldwide for the optimal management of diabesity to date $[12,16]$.

The therapeutic armamentarium for management of T2DM ranges from the conventional oral antidiabetic (OAD) medications and insulin therapy along with lifestyle modifications to the newer class of drugs including glucagon-like peptide-1 receptor agonists (GLP-1 RAs) and sodium-glucose co-transporter-2 (SGLT2) inhibitors. SGLT2 inhibitors are a class of OADs that function by reducing renal tubular glucose reabsorption, thereby reducing blood glucose without stimulating insulin release [17].

GLP-1 RAs are a class of injectable drugs used for the management of T2DM. Currently, few drugs in this class are approved globally, and the rest are at various stages of approval. GLP-1 RAs aid in glycaemic control through multiple mechanisms. In a glucose-dependent mechanism, GLP-1 RAs stimulate insulin secretion and suppress inappropriately elevated glucagon levels. These drugs are known to delay gastric emptying and promote satiety and are associated with a reduced risk of hypoglycaemia [18-21]. Accordingly, GLP-1 RAs can be considered as calorie restriction mimetics or calorie restriction facilitators. Furthermore, these drugs aid in modest weight loss unlike the weight gain typically observed with some of the antidiabetic medications and are being explored for their potential to address all components of MetS including obesity, hypertension, dyslipidaemia, polycystic ovary syndrome (PCOS) and fatty liver [22-24].

Diabetes associations across the globe have been formulating and updating guidelines on GLP-1 RAs in T2DM management to optimise and provide targeted treatment for the effective use of this class of agents. As there remains a gap in guidance towards GLP-1 RA therapy in the South Asian region, this report attempts to address any issues or specific guidance to realworld healthcare practitioners (HCPs) in order to manage T2DM using GLP-1 RAs in this geography.

The objective of this report is to develop a consensus for the use of GLP-1 RAs in the management of T2DM in the South Asian population based on a pragmatic review of clinical evidence and insights from experts representing 
India, Pakistan, Bangladesh, Nepal, Sri Lanka, Afghanistan and the Maldives. In addition, this report provides an objective snapshot of consensus practices for HCPs among the participating countries regarding the characteristics of ideal GLP-1 RA candidates, timing of therapy initiation, parameters to be monitored during therapy, use in special populations, cost implications, management of adverse events (AEs) and strategies to combat multidimensional barriers to support adherence to GLP-1 RA therapy.

\section{Current Approval Status of GLP-1 RAs in South Asia}

The approval status of GLP-1 RAs in the participating South Asian countries is presented in Table 2. Other GLP-1 RAs, namely albiglutide $\mathrm{QW}$, exenatide $\mathrm{QW}$ and semaglutide $\mathrm{QW}$, approved by the US Food and Drug Association (USFDA), are currently not available in the South Asian market and are in approval stages in South Asia. However, none of the GLP-1 RAs have been listed in the national list of essential medicines in any of the South Asian countries to date.

\section{METHODOLOGY}

This report is based on a review of published guidelines and clinical evidence from metaanalyses, systematic reviews, randomised controlled trials, prospective and retrospective studies, and real-world data on GLP-1 RA use in the management of T2DM. Conference abstracts were not included for this report. The consensus was developed in accordance with the American Association of Clinical Endocrinologists' protocol [25]. Recommendations were based on clinical importance coupled with four intuitive levels of evidence as presented in Table 3. In case of little or no evidence, the panel relied on logical empiricism, judgement and consensus to make the recommendations. The panellists of the consensus were endocrinologists representing South Asian countries including India, Pakistan, Bangladesh, Nepal, Sri Lanka, Afghanistan and the Maldives. This report was developed following a preliminary consensus meeting held in New Delhi, India on 2 June 2018, followed by another meeting held in Colombo, Sri Lanka, on 1 September 2018. These meetings were sponsored by Eli Lilly, India, and were organized under the auspices of the steering committee. The sponsor had no formal voting during the consensus, and had no influence on the development of consensus statements or this manuscript.

\section{Compliance with Ethics Guidelines}

This article is based on previously conducted studies and does not contain any studies with human participants or animals performed by any of the authors.

\section{RATIONALE}

The incretin system or incretin hormones principally include glucagon-like peptide-1 (GLP-1) and glucose-dependent insulinotropic polypeptide (GIP), which are released by the gut endocrine cells in response to meal intake [26].

Table 2 Current approval status of GLP-1 RAs in South Asia

\begin{tabular}{|c|c|c|c|c|c|c|c|}
\hline \multirow[t]{2}{*}{ GLP-1 RA } & \multicolumn{7}{|c|}{ Approval in participating countries } \\
\hline & Afghanistan & Bangladesh & India & Maldives & Nepal & Pakistan & Sri Lanka \\
\hline Dulaglutide (QW) & & $\checkmark$ & $\boldsymbol{V}$ & & & $\checkmark$ & \\
\hline Exenatide (BID) & & & $\boldsymbol{V}$ & & & $\checkmark$ & \\
\hline Liraglutide (QD) & & $\boldsymbol{V}$ & $\boldsymbol{V}$ & & $\checkmark$ & $\checkmark$ & $\checkmark$ \\
\hline Lixisenatide (QD) & & & $\boldsymbol{V}$ & & & & \\
\hline
\end{tabular}

$G L P$-1 RA glucagon-like peptide-1 receptor agonist 
Table 3 Evidence and recommendation grading according to the American Association of Clinical Endocrinologists' guidelines

\begin{tabular}{llll}
\hline $\begin{array}{l}\text { Evidence } \\
\text { level }\end{array}$ & Semantic descriptor (reference methodology) & Grades & Recommendation \\
\hline 1 & Meta-analyses of RCTs, RCTs & A & Strong \\
2 & $\begin{array}{l}\text { Meta-analyses of non-randomised prospective or case-controlled trials, non- } \\
\text { RCT, prospective cohort study, retrospective case-control study }\end{array}$ & B & Intermediate \\
3 & $\begin{array}{l}\text { Cross-sectional study, surveillance study (registries, surveys, epidemiologic study, } \\
\text { retrospective chart review, mathematical modelling of database), consecutive } \\
\text { case series, single case reports }\end{array}$ & Weak & \\
& No evidence (theory, opinion, consensus, review or preclinical study) & D & No evidence \\
\hline
\end{tabular}

RCTs randomised controlled trials

GLP-1 lowers blood glucose through stimulation of insulin secretion (and production) and suppression of glucagon secretion in a glucosedependent manner [22]. GLP-1 is a pluripotent incretin hormone in humans which exerts multiple physiological actions, and the main targets of GLP-1 and its actions are depicted in Fig. 1 [27].

The incretin hormones may be responsible for up to $70 \%$ of postprandial insulin secretion. Their effects are progressively amplified from the beginning of a meal in response to increase in plasma glucose concentrations. The incretin effect is severely reduced or absent in patients with T2DM. Impaired incretin effect in T2DM

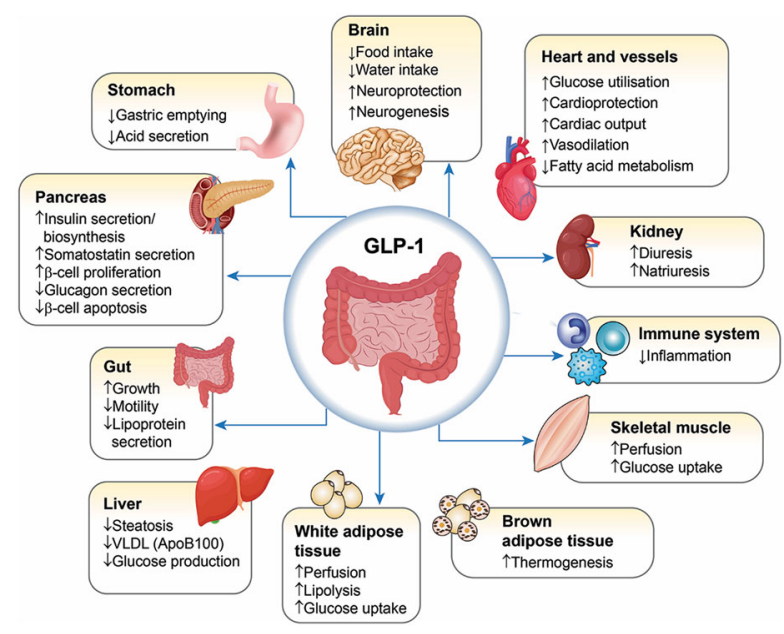

Fig. 1 GLP-1 target organs and its action. GLP-1 glucagon-like peptide-1, $V L D L$ very low density lipoprotein could be due to impaired incretin hormone secretion (incretin hormone deficiency) and/or defective insulinotropic action of the incretin hormones (incretin hormone resistance). Despite controversies in the literature, the data indicate the impaired incretin effect in patients with T2DM to be associated with defective insulin secretory effects of GIP and GLP-1 as opposed to defective secretion of the incretin hormones [28]. In the case of GLP-1, their secretion in patients with T2DM is impaired; however, the insulinotropic and glucagon-suppressive actions are preserved. This forms the rationale for incretin-based therapy in T2DM [26].

Interestingly, the point of action of GLP-1 RAs extends beyond $\beta$-cells, and these agents effectively act on the cells of the islets of Langerhans as a whole to bring in equilibrium in both pre-diabetic and diabetic conditions as illustrated in an islet-centric fulcrum (Fig. 2).

Exogenous GLP-1 administration may restore blood glucose regulation to near normal levels in patients with T2DM whose incretin effect is reduced [26]. GLP-1 RAs or incretin mimetics are agonists of the GLP-1 receptors. GLP-1 RAs possess pleiotropic effects similar to endogenous GLP-1 $[29,30]$.

\section{MECHANISM OF ACTION OF GLP-1}

GLP-1 elicits protracted glucose-lowering in a glucose-dependent manner owing to its 


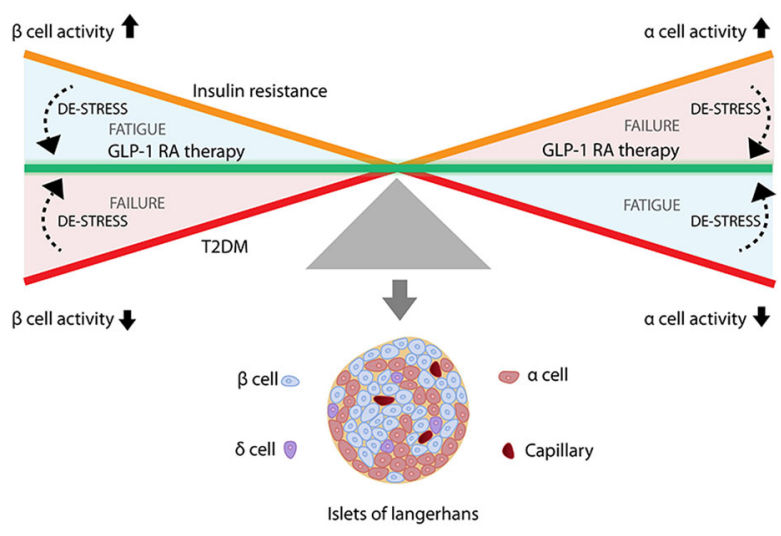

Fig. 2 Islet-centric fulcrum for GLP-1 RA-based therapy. $G L P-1 \quad R A$ glucagon-like peptide-1 receptor agonist, $T 2 D M$ type 2 diabetes mellitus

insulinotropic mechanism of action in pancreatic $\beta$-cells. In contrast, its non-insulinotropic action is marked by extra-pancreatic effects which might be beneficial for the prevention and treatment of diabetes-related complications and comorbidities presented independently of glycaemic control.

\section{Insulinotropic Mechanism of Action}

The insulinotropic activity of GLP-1 is (at least) partly exerted through interaction with the GLP-1 receptors located on the cell membrane of the $\beta$-cells. Figure 3 depicts the molecular mechanisms underlying the insulinotropic effects of GLP-1 along with a brief summary of the mechanism of action [31, 32].

\section{Non-Insulinotropic Actions of GLP-1}

Suppression of glucagon expression by GLP-1 is considered to be clinically important as GLP-1 loses its inhibitory effect on glucagon secretion at hypoglycaemic levels. However, there is uncertainty around the mechanism whereby this occurs [33, 34]. GLP-1 inhibits meal-induced acid secretions, gastric emptying, gastrointestinal (GI) motility and pancreatic secretions. The effects of GLP-1 on gastric functions are mediated through vagal pathways $[31,35]$.

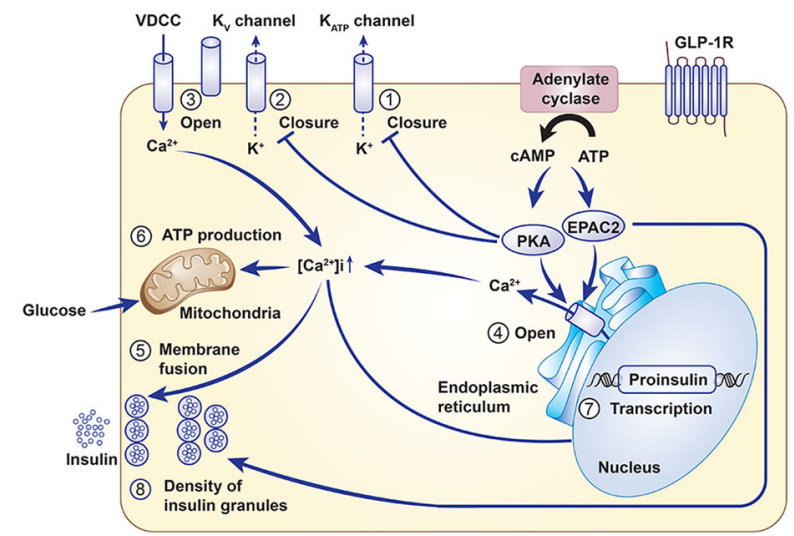

Fig. 3 Molecular mechanisms underlying insulinotropic effects of GLP-1. Binding of GLP-1 to GLP-1 receptors leads to the activation of adenylate cyclase and elevation of intracellular cAMP levels. Increased cAMP levels subsequently activate PKA and the cAMP-regulated guanine nucleotide exchange factor II (cAMP-GEFII, also known as Epac2). Activation of PKA leads to the closure of $\mathrm{K}_{\mathrm{ATP}}$ channels, thereby facilitating membrane depolarisation (1). PKA activation also leads to the inhibition of delayed rectifying $\mathrm{K}^{+}\left(\mathrm{K}_{\mathrm{v}}\right)$ channels, which is a negative regulator of insulin secretion in pancreatic $\beta$-cells, thus resulting in prolongation of action potentials (2). Depolarisation results in the opening of voltage-gated $\mathrm{Ca}^{2+}$ channels, leading to an increase in intracellular $\mathrm{Ca}^{2+}$ concentrations (3). Increased intracellular $\mathrm{Ca}^{2+}$ concentrations mobilise $\mathrm{Ca}^{2+}$ from intracellular stores through PKA- and Epac2dependent mechanisms (4). The increased $\mathrm{Ca}^{2+}$ concentration leads to the events as follows: insulin-containing granules fuse with the plasma membrane and insulin is secreted from $\beta$-cells (5); $\mathrm{Ca}^{2+}$-induced $\mathrm{Ca}^{2+}$ mobilisation from intracellular stores stimulates ATP synthesis in mitochondria which further enhances membrane depolarisation through $\mathrm{K}_{\text {ATP }}$ channel closure (6); Transcription of the proinsulin gene is promoted (7); Activation of EPAC2 also increases the density of insulin-containing granules near the plasma membrane to potentiate insulin secretion from $\beta$-cells (8). cAMP cyclic adenosine monophosphate, GLP-1 glucagon-like peptide-1, PKA protein kinase A

GLP-1 influences feeding behaviour and body weight both through direct (by entering the brain via the systemic circulation and by crossing the blood-brain barrier) and indirect pathways (via neural afferents) which are largely mediated by the central nervous system. Evidence from preclinical data demonstrates that central GLP-1 induces satiety by affecting 
both homeostatic and reward-associated food intake, and such effects seem to be mediated by the GLP-1 receptor [36].

GLP-1 aids in $\beta$-cell proliferation and survival. An increase in $\beta$-cell mass and decrease in apoptotic $\beta$-cells were demonstrated in several animal studies $[37,38]$

\section{CLASSIFICATION OF GLP-1 RAS}

On the basis of the duration of action, GLP-1 RAs can be classified as short-acting, intermediate-acting, long-acting and continuous-acting GLP-1 RAs (Table 4). The differences between short-acting and long-acting GLP-1 RAs in terms of their effectiveness on several physiological parameters are presented in Table 5 [39].

\section{Short-Acting GLP-1 RAs}

Short-acting GLP-1 RAs provide short-lived GLP-1 receptor activation. Although resistant to dipeptidyl peptidase-4 (DPP4), GLP-1 RAs have a plasma half-life of about $2-4 \mathrm{~h}$ and are eliminated through the renal system. Short-acting GLP-1 RAs primarily lower postprandial blood glucose (PPBG) levels through delayed gastric emptying because of which the rate of glucose entry into the duodenum and subsequently into the circulation is delayed [22, 39].

Table 4 Classification of GLP-1 RAs

\begin{tabular}{lll}
\hline Classification & Compound & Half-life \\
\hline Short-acting & Exenatide & $<12 \mathrm{~h}$ \\
& Lixisenatide & \\
Intermediate- & Liraglutide & $12-24 \mathrm{~h}$ \\
acting & \\
Long-acting & Exenatide LAR $>24 \mathrm{~h}$ to 1 month \\
& Albiglutide \\
& Semaglutide \\
Continuous-acting & ITCA $650^{\mathrm{a}}$ & $>1$ month \\
\hline
\end{tabular}

$G L P-1 \quad R A$ glucagon-like peptide-1 receptor agonist, $L A R$ long-acting release

${ }^{a}$ ITCA 650 is an investigational drug

\section{Intermediate-Acting GLP-1 RAs}

The intermediate-acting GLP-1 RAs liraglutide is an acylated GLP-1 RA that exhibits a prolonged half-life of $13 \mathrm{~h}$. Liraglutide is endogenously metabolised in a similar manner to large proteins without a specific organ as a major route of elimination [40].

\section{Long-Acting GLP-1 RAs}

Long-acting GLP-1 RAs keep activating the GLP1 receptors continuously at the recommended doses. Long-acting GLP-1 RAs lower blood glucose primarily by stimulating insulin secretion and reducing glucagon levels. Greater reductions in plasma glycated haemoglobin (HbA1c) are observed with long-acting GLP-1 RAs compared to short-acting GLP-1 RAs due to their consistently high plasma levels. The reduction in body weight with long-acting GLP-1 RAs is comparable to those with short-acting GLP-1 RAs [39].

\section{Continuous-Acting GLP-1 RA (Implantable GLP-1 RAs)}

A miniature implantable GLP-1 RA, ITCA 650, is hereby classified as a continuous-acting GLP-1 RA. ITCA-650, with an osmotic pump system, delivers zero-order continuous subcutaneous exenatide at a precise, pre-set rate for up to 12 months. Although an invasive therapy, ITCA 650 is advantageous in terms of injection frequency and effort needed from the patient. However, uncertainty about the usefulness of the therapy during illness, fasting or sudden change in the renal/hepatic parameters is considered one of the limitations [41].

\section{PHARMACOKINETICS AND PHARMACODYNAMICS OF GLP-1 RAs}

The GLP-1 RAs are administered weekly to twice daily according to the formulation. The pharmacokinetics and pharmacodynamics of this 
Table 5 Comparison between short-acting and long-acting GLP-1 RAs

\begin{tabular}{lll}
\hline Parameters & Short-acting GLP-1 RAs & Long-acting GLP-1 RAs \\
\hline Effects & & \\
Fasting blood glucose levels & Modest reduction & Strong reduction \\
Postprandial hyperglycaemia & Strong reduction & Modest reduction \\
Fasting insulin secretion & Modest stimulation & Strong stimulation \\
Postprandial insulin secretion & Reduction & Modest stimulation \\
Glucagon secretion & Reduction & Reduction \\
Gastric emptying rate & Deceleration & No effect \\
Blood pressure & Reduction & Reduction \\
Heart rate & No effect or small increase $(0-2 \mathrm{bpm})$ & Moderate increase $(2-5 \mathrm{bpm})$ \\
Body weight reduction & $1-5 \mathrm{~kg}$ & $2-5 \mathrm{~kg}$ \\
Occurrence of nausea & $20-50 \%$, attenuates slowly & $20-40 \%$, attenuates quickly $(\sim 4-8$ weeks) \\
& (weeks to many months) & \\
\hline
\end{tabular}

GLP-1 RA glucagon-like peptide-1 receptor agonist

class of drugs are presented in Tables 6 and 7, respectively.

\section{OVERVIEW OF PRESCRIBING INFORMATION/PACKAGE INSERT OF GLP-1 RAs IN SOUTH ASIA}

An overview of the prescribing information/package insert of GLP-1 RAs pertaining to all GLP-1 RAs approved in South Asia as well as the ones to be launched in the near future is provided in Table 8 with a brief summary as follows.

GLP-1 RAs including dulaglutide, exenatide BID, liraglutide, lixisenatide and semaglutide are indicated in adults with T2DM as an adjunct to diet and exercise to improve glycaemic control. Dulaglutide is even recommended as monotherapy in India. In addition to glycaemic control, liraglutide has been indicated in adults with established CVD to reduce the risk of major adverse cardiovascular events. GLP-1 RAs are contraindicated in patients with prior hypersensitivity to the respective drug or any product components, personal or family history of medullary thyroid carcinoma (MTC) or in patients with multiple endocrine neoplasia syndrome type 2 (MEN2). These GLP-1 RAs are not to be used in the treatment of type 1 diabetes mellitus or diabetes ketoacidosis. In case of suspected pancreatitis, GLP-1 RAs are to be discontinued and should not be restarted if pancreatitis is confirmed.

A detailed description on the use of GLP-1 RA in special populations and AEs common for GLP-1 RAs is given in the following sections.

\section{OVERVIEW OF GLP-1 RA RECOMMENDATIONS FOR T2DM MANAGEMENT FROM DIABETIC ASSOCIATIONS ACROSS THE WORLD}

Diabetes, a chronic and complex condition, demands continuous and individualised care with a multipronged approach. Diabetes management is comprehensive and extends beyond glycaemic control in T2DM patients, often taking into consideration other comorbidities associated with the condition $[55,56]$.

Guidelines for the management of diabetes intend to provide evidence-based 


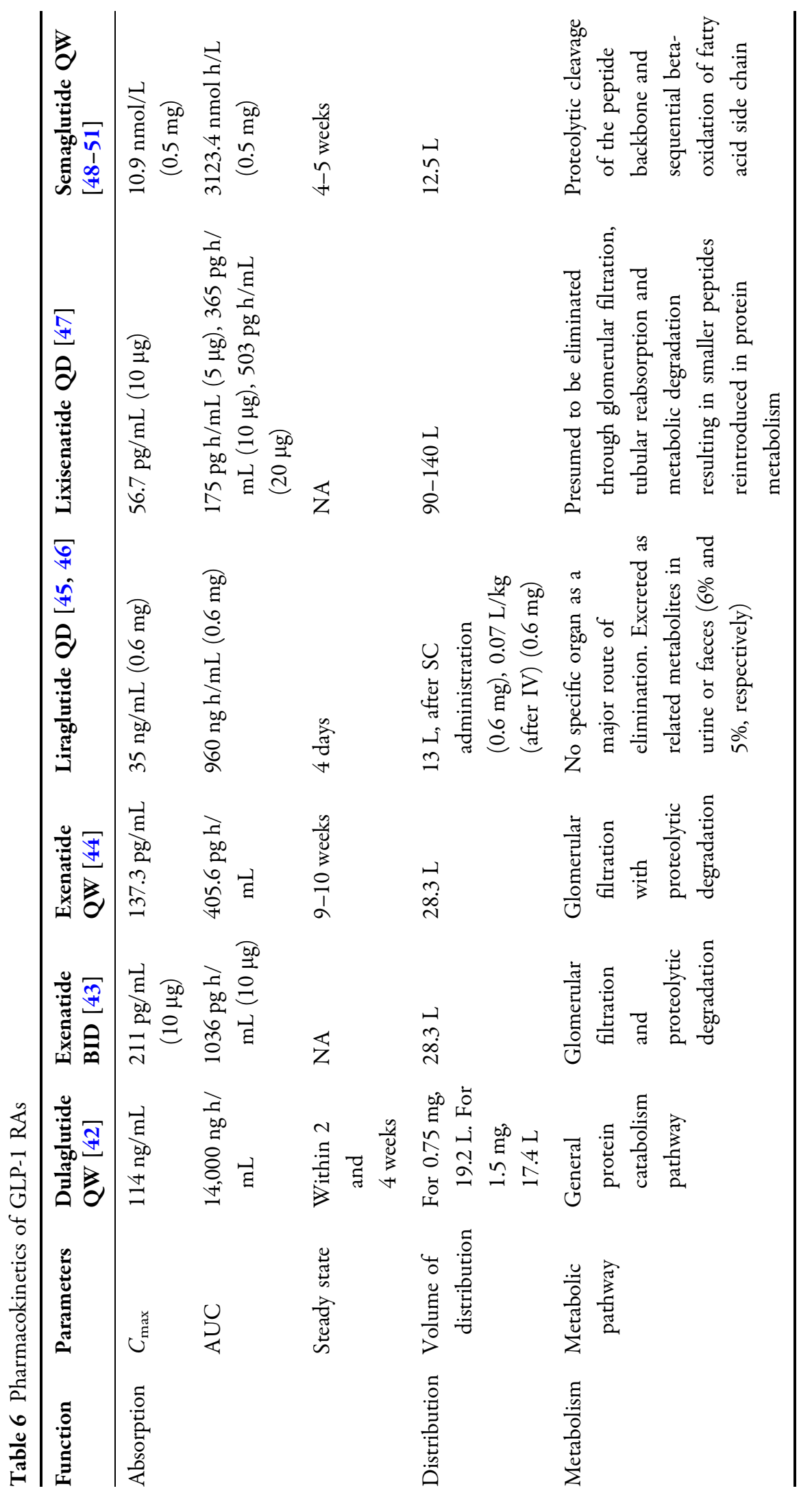




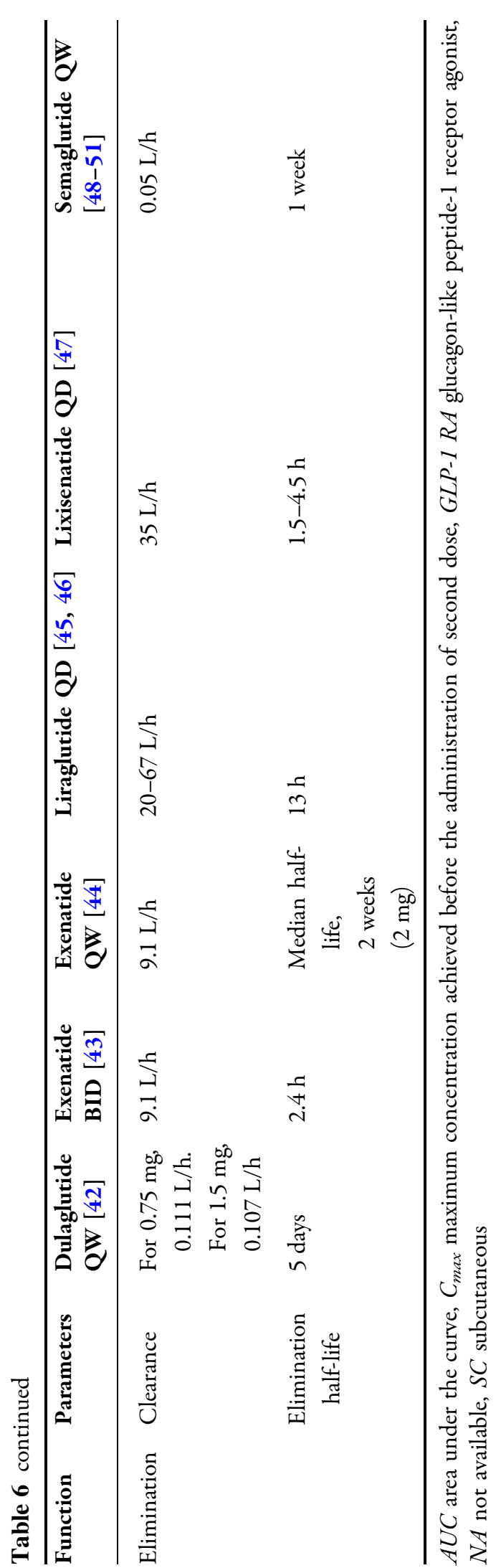

recommendations to physicians across the world for diagnosis, management and follow-up [57]. Consequently, guidelines provide a comprehensive picture and awareness to the practitioner to confront the situation effectively.

A study conducted in the USA reported that a periodic evaluation of $\mathrm{HbA} 1 \mathrm{c}$ and lipid profile as recommended by the guidelines had resulted in a significant decrease in the rates of hospitalisation due to vascular, renal and other diabetes-related complications [58].

Table 9 summarises the key points on the recommendation of GLP-1 RAs in T2DM management from selected diabetic associations across the world.

The usefulness of GLP-1 analogues in glycaemic control with low risk of hypoglycaemia and body weight reduction has been taken into consideration in all the guidelines listed in Table 9.

All the guidelines listed in Table 9 recommend GLP-1 RAs as a part of dual or triple therapy in combination with OAD drugs with or without insulin in accordance with the respective algorithm $[55,59,60,62-64]$.

In the consensus statement by the American Association of Clinical Endocrinologists and American College of Endocrinology (AACE/ ACE), GLP-1 RA is recommended as monotherapy in individuals with $\mathrm{HbA} 1 \mathrm{c}<7.5 \%$. In addition, GLP-1 RA is recommended in pre-diabetic patients if glycaemia is not normalised with medications such as metformin and acarbose [59]. AACE/ACE guidelines strive for stringent HbA1c targets $(\leq 6.5 \%)$ compared to American Diabetes Association-European Association for the Study of Diabetes (ADA/EASD) guidelines which aim for an HbA1c target of 7\% [68].

It is important to note that both ADA/EASD and AACE/ACE guidelines endorse the overall cardiovascular and pancreatic safety of incretin therapies [68].

Associations like International Diabetes Federation, Research Society for the Study of Diabetes in India and Pakistan Endocrine Society take the aspect of affordability into consideration while recommending GLP-1 RAs [62, 69].

From a South Asian perspective, countries including Bangladesh do not mention GLP-1 
Table 7 Pharmacodynamics of GLP-1 RAs

\begin{tabular}{|c|c|c|c|c|}
\hline GLP-1 RA & $\begin{array}{l}\text { Effect on insulin } \\
\text { secretion }\end{array}$ & $\begin{array}{l}\text { Effect on glucagon } \\
\text { secretion }\end{array}$ & Effect on GI motility & $\begin{array}{l}\text { Electrophysiological } \\
\text { effect }\end{array}$ \\
\hline $\begin{array}{l}\text { Dulaglutide } \\
\text { QW [42] }\end{array}$ & $\begin{array}{l}\text { Increase in } 1 \text { st and } \\
2 \text { nd phase insulin } \\
\text { secretion }\end{array}$ & $\begin{array}{l}\text { Reduces fasting glucagon } \\
\text { concentration by } 1.71 \\
\text { and } 2.05 \mathrm{pmol} / \mathrm{L}\end{array}$ & $\begin{array}{l}\text { Causes a delay in gastric } \\
\text { emptying (the delay is } \\
\text { largest with the first dose } \\
\text { and diminishes with } \\
\text { subsequent doses) }\end{array}$ & $\begin{array}{l}\text { Does not prolong QTc } \\
\text { interval (at supra- } \\
\text { therapeutic doses of } \\
4 \mathrm{mg} \text { and } 7 \mathrm{mg} \text { ) }\end{array}$ \\
\hline $\begin{array}{l}\text { Exenatide } \\
\text { BID [43] }\end{array}$ & $\begin{array}{l}\text { Increase in } 1 \text { st and } \\
2 \text { nd phase insulin } \\
\text { secretion }\end{array}$ & $\begin{array}{l}\text { Moderates glucagon } \\
\text { secretions and lowers } \\
\text { serum concentrations } \\
\text { during periods of } \\
\text { hyperglycaemia }\end{array}$ & Delays gastric emptying & $\begin{array}{l}\text { Not associated with } \\
\text { clinically meaningful } \\
\text { prolongation of QTc } \\
\text { interval }\end{array}$ \\
\hline $\begin{array}{l}\text { Exenatide } \\
\text { QW [52] }\end{array}$ & $\begin{array}{l}\text { 1st and } 2 \text { nd phase } \\
\text { insulin secretion } \\
\text { enhancement }\end{array}$ & $\begin{array}{l}\text { Moderates glucagon } \\
\text { secretion and lowers } \\
\text { glucagon concentration } \\
\text { during periods of } \\
\text { hyperglycaemia }\end{array}$ & Slows gastric emptying & $\begin{array}{l}\text { Not associated with } \\
\text { prolongation of QTc }\end{array}$ \\
\hline $\begin{array}{l}\text { Liraglutide } \\
\text { QD } \\
{[45,52]}\end{array}$ & $\begin{array}{l}\text { 1st and } 2 \text { nd phase of } \\
\text { insulin secretion } \\
\text { enhancement }\end{array}$ & $\begin{array}{l}\text { Lowers glucagon } \\
\text { secretion. Does not } \\
\text { impair normal } \\
\text { glucagon response to } \\
\text { low glucose } \\
\text { concentrations }\end{array}$ & Delays gastric emptying & $\begin{array}{l}\text { Does not produce QTc } \\
\text { interval (up to } 1.8 \mathrm{mg} \text { ) }\end{array}$ \\
\hline $\begin{array}{l}\text { Lixisenatide } \\
\text { QD } \\
{[47,53]}\end{array}$ & $\begin{array}{l}\text { Resensitisation of } 1 \text { st } \\
\text { phase insulin } \\
\text { secretion and } \\
\text { increase in } 2 \mathrm{nd} \\
\text { phase insulin } \\
\text { secretion }\end{array}$ & $\begin{array}{l}\text { Glucagon secretion is } \\
\text { suppressed }\end{array}$ & Slows gastric emptying & $\begin{array}{l}\text { There was no mean } \\
\text { increase in QTc even } \\
\text { at supra-therapeutic } \\
\text { doses }\end{array}$ \\
\hline $\begin{array}{r}\text { Semaglutide } \\
\text { QW [48] }\end{array}$ & $\begin{array}{l}\text { Increase in } 1 \text { st and } \\
2 \text { nd phase insulin } \\
\text { secretion }\end{array}$ & $\begin{array}{l}\text { Lowers fasting and } \\
\text { postprandial glucagon } \\
\text { concentrations }\end{array}$ & $\begin{array}{l}\text { Delays early postprandial } \\
\text { gastric emptying }\end{array}$ & $\begin{array}{l}\text { Does not prolong QTc } \\
\text { interval to any } \\
\text { clinically relevant } \\
\text { extent ( } 1.5 \text { times the } \\
\text { recommended dose) }\end{array}$ \\
\hline
\end{tabular}

GI gastrointestinal, GLP-1 RA glucagon-like peptide-1 receptor agonist

a QTc: in electrocardiography, the duration of the QT interval adjusted for the patient's heart rate 
Table 8 Overview of the prescribing information/package insert of GLP-1 RAs in South Asia

\begin{tabular}{|c|c|c|}
\hline Indications $[42-45,47,48,54]$ & $\begin{array}{l}\text { Contraindications/limitations } \\
{[42-45,47,48,54]}\end{array}$ & $\begin{array}{l}\text { Warnings and precautions } \\
{[42-45,47,48,54]}\end{array}$ \\
\hline $\begin{array}{l}\text { As an adjunct to diet and exercise in } \\
\text { adults with T2DM. Recommended as } \\
\text { monotherapy in a few countries (e.g. } \\
\text { dulaglutide in India). Indicated in } \\
\text { adults (liraglutide) with established } \\
\text { CVD to reduce the risk of major } \\
\text { adverse CV events }\end{array}$ & $\begin{array}{l}\text { Personal or family history of MTC or } \\
\text { in patients with MEN2. Prior serious } \\
\text { hypersensitivity. Not to be used in } \\
\text { T1DM or diabetic ketoacidosis. Lack } \\
\text { of data in patients with pancreatitis }\end{array}$ & $\begin{array}{l}\text { Risk of MTC. Pancreatitis—to be } \\
\text { discontinued promptly. } \\
\text { Hypoglycaemia - reduction of doses } \\
\text { of concomitant medications. Renal } \\
\text { impairment - patients reporting } \\
\text { severe GI adverse events. } \\
\text { Hypersensitivity. Not recommended } \\
\text { in patients with severe GI diseases }\end{array}$ \\
\hline
\end{tabular}

$C V$ cardiovascular, $C V D$ cardiovascular disease, GI gastrointestinal, GLP-1 RA glucagon-like peptide-1 receptor agonist, MEN2 multiple endocrine neoplasia type 2, MTC medullary thyroid carcinoma, TIDM type 1 diabetes mellitus, T2DM type 2 diabetes mellitus

RAs in region-specific guidelines, which limits the prescription of GLP-1 RAs by HCPs in those countries.

\section{CLINICAL EVIDENCE ON GLP-1 RAs LICENSED IN SOUTH ASIA}

\section{Efficacy and Safety of GLP-1 RAs (Clinical Trial and Real-World Evidence)}

As the proposed consensus on GLP-1 RAs is based on a pragmatic review of clinical evidence and insights from experts across South Asia, pragmatic review relies on detailed and thorough analysis of clinical evidence to draw inferences. The clinical trial programme of GLP1 RAs licensed or under regulatory approval in one or more South Asian countries is presented in Table 10. The available evidence on the efficacy with respect to glycaemic control and change in body weight and safety (nausea and vomiting) from the studies included in the respective clinical trial programme of the GLP-1 RAs along with a few others including realworld studies is presented according to the prescription pattern (monotherapy or in combination with other oral antidiabetic medications and/or insulin) and further classified on the basis of the geography of the reported patient groups as global, global including South Asia and/or South Asia specific in
Supplementary Information. The evidence derived from meta-analyses, systematic reviews and pooled analyses is, however, discussed across multiple sections on clinical impact and special populations. Clinical evidence comparing the efficacy of GLP-1 RAs head-to-head and with other classes of antidiabetic agents such as SGLT2 inhibitors (SGLT2i) is exclusively covered in this section.

Several head-to-head comparative trials and retrospective studies involving GLP-1 RAs have been conducted and a few pivotal studies with key inferences are presented in Table 11.

\section{GLP-1 RAs: CLINICAL IMPACT AND BENEFITS}

GLP-1 RAs are known for their glycaemic control as well as extra-glycaemic benefits which are elaborated below.

\section{Glycaemia}

GLP-1 RAs improve glucose homeostasis by enhancing glucose-dependent insulin secretion by suppressing inappropriately elevated glucagon levels, both in fasting and postprandial states, and by delaying gastric emptying [22]. This cumulatively helps in the reduction of HbA1c levels in patients with T2DM. Changes in HbA1c levels due to GLP-1 RA administration 


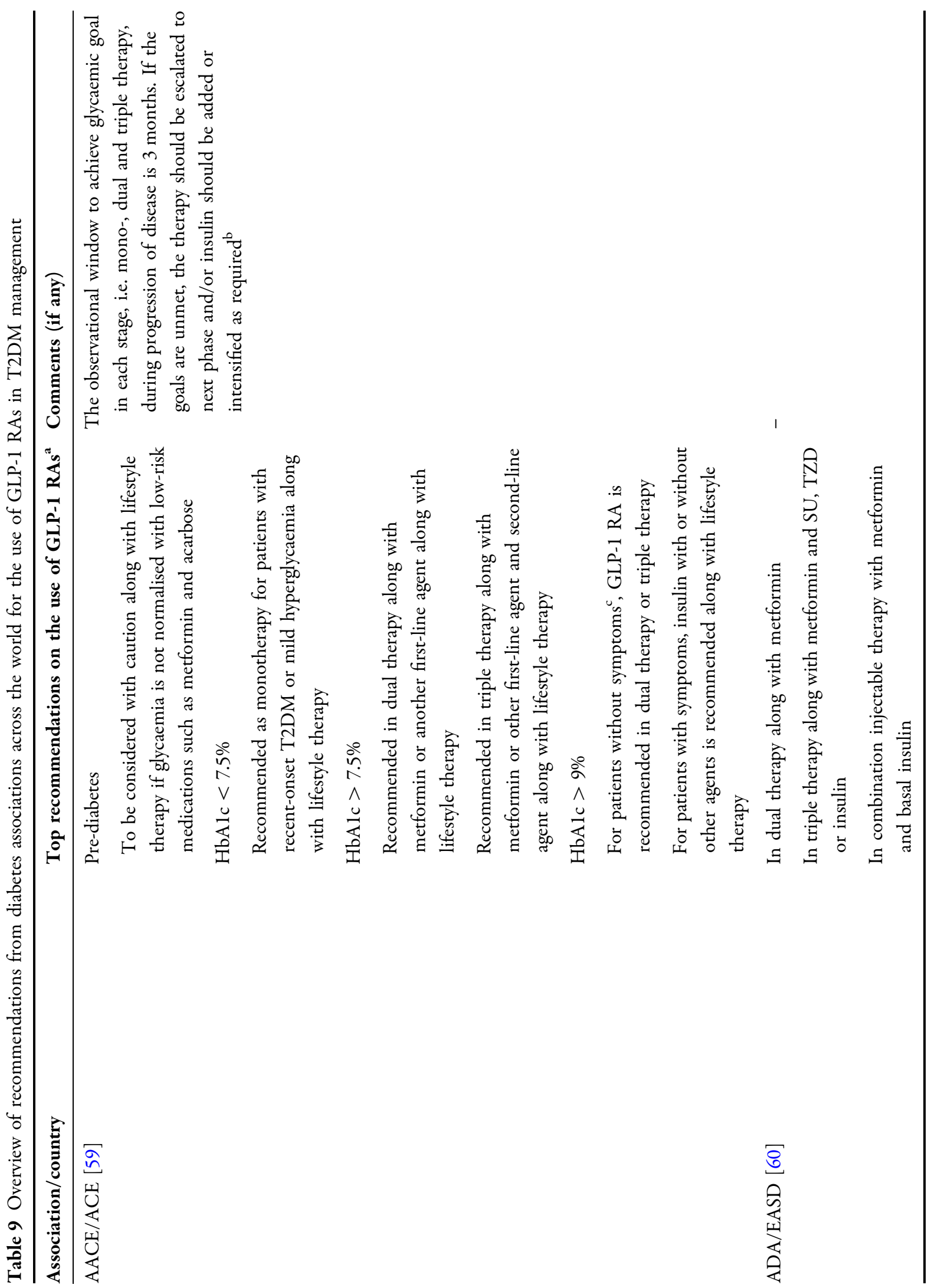









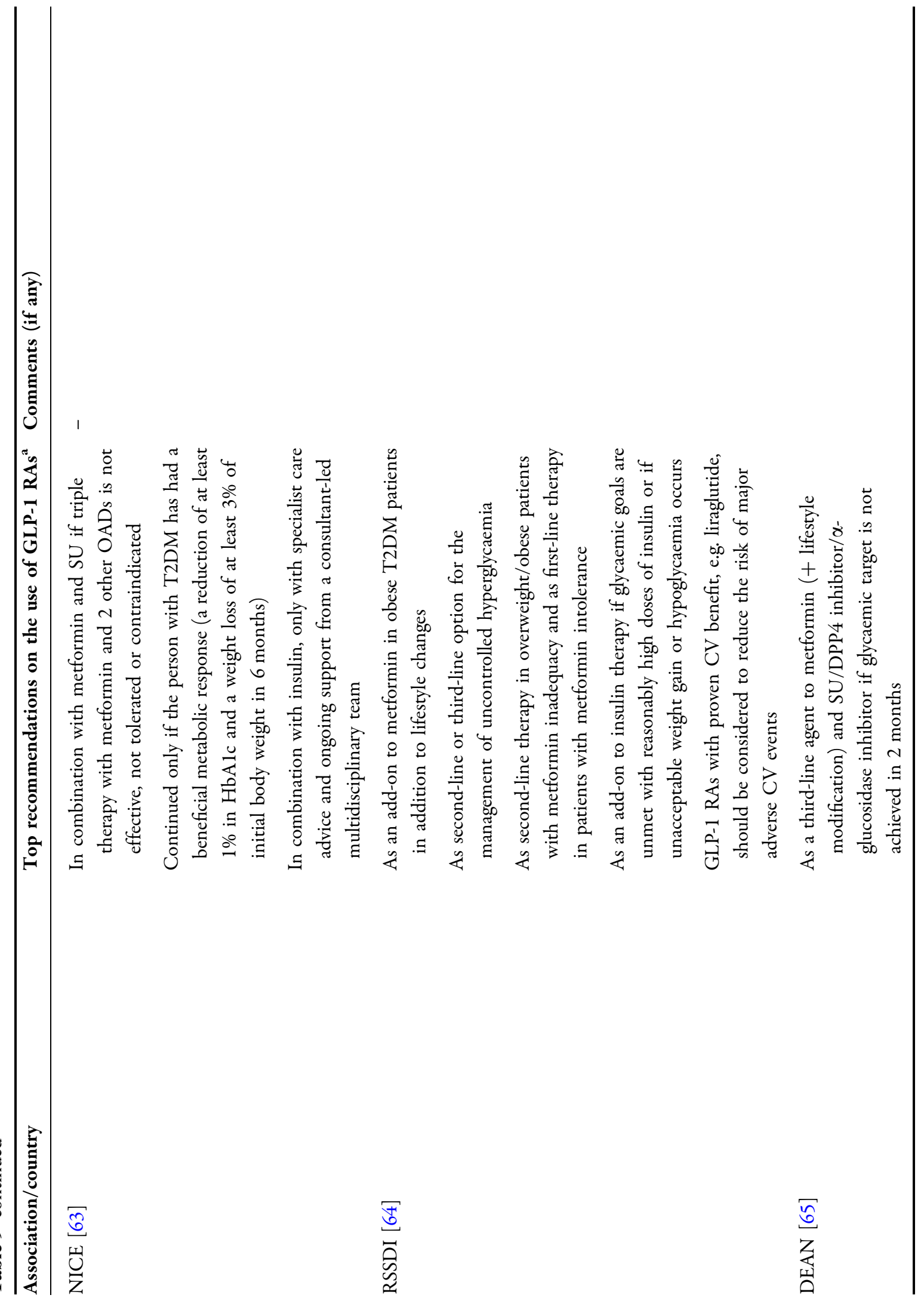




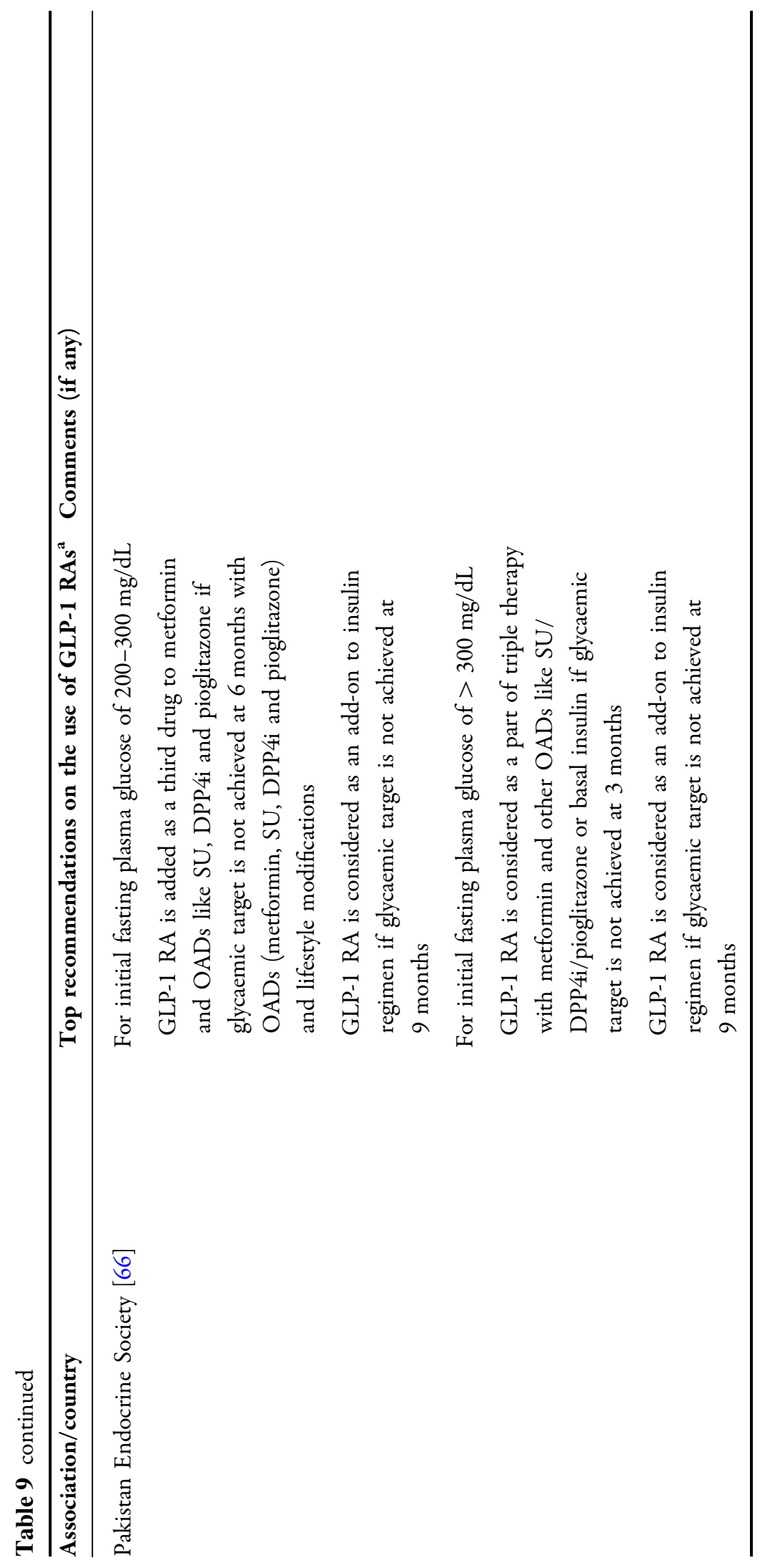




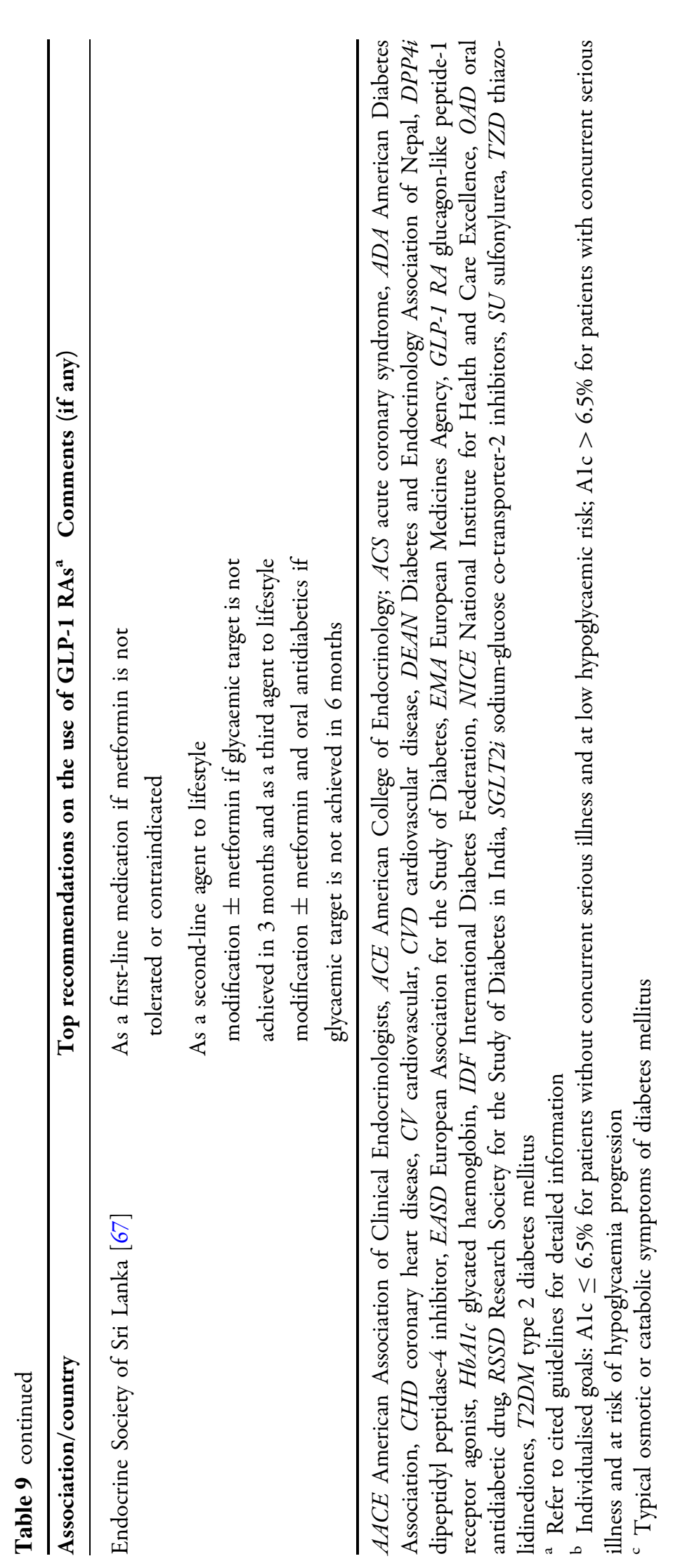


Table 10 GLP-1 RAs clinical trial programme

\begin{tabular}{ccc}
\hline Dulaglutide QW & Exenatide QW & Liraglut \\
\hline Key clinical trials for & GLP-1RAs (phase 3) & \\
AWARD-1 & AMIGO trials & LEAD-1 \\
AWARD-2 & DURATION-1 & LEAD-2 \\
AWARD-3 & DURATION-2 & LEAD-3 \\
AWARD-4 & DURATION-3 & LEAD-4 \\
AWARD-5 & DURATION-4 & LEAD-5 \\
AWARD-6 & DURATION-5 & LEAD-6 \\
AWARD-7 & DURATION-6 & \\
AWARD-8 & DURATION-7 & \\
AWARD-9 & DURATION-8 & \\
AWARD-10 & & \\
AWARD-1 $1^{\text {a }}$ & &
\end{tabular}

\begin{tabular}{|c|c|}
\hline GETGOAL-MONO & SUSTAIN-1 \\
\hline GETGOAL-MONO & SUSTAIN-2 \\
\hline Japan & SUSTAIN-3 \\
\hline GETGOAL-M & SUSTAIN-4 \\
\hline GETGOAL-M-Asia & SUSTAIN-5 \\
\hline GETGOAL-X & SUSTAIN-7 \\
\hline GETGOAL-F1 & SUSTAIN-8 \\
\hline GETGOAL-S & SUSTAIN-9 \\
\hline GETGOAL-P & \\
\hline
\end{tabular}

GETGOAL-L

GETGOAL-L-Asia

GETGOAL-Duo-1

Cardiovascular outcome trials for GLP-1 RAs
REWIND
EXSCEL $^{\mathrm{c}}$
LEADER
ELIXA
SUSTAIN-6

AMIGO AC2993 diabetes management for improving glucose outcomes (exenatide, $10 \mu \mathrm{g}$ BID), AWARD assessment of weekly administration of LY2189265 in diabetes (dulaglutide, $0.75 \mathrm{mg}$ or $1.5 \mathrm{mg}$ QW), DURATION diabetes therapy utilization: researching changes in $\mathrm{A1C}$, weight and other factors through intervention with exenatide QW (extendedrelease exenatide, $2 \mathrm{mg}$, once weekly), ELIXA evaluation of lixisenatide in acute coronary syndrome (lixisenatide, maximum dose $20 \mu \mathrm{g}$ per day), EXSCEL exenatide study of cardiovascular event lowering trial (exenatide QW, $2 \mathrm{mg}$ ), GETGOAL GLP-1 agonist AVE0010 in patients with type 2 diabetes mellitus for glycaemic control and safety evaluation (lixisenatide, $20 \mu \mathrm{g}$ once daily), GLP-1 RA glucagon-like peptide-1 receptor agonist, $L E A D$ liraglutide effect and action in diabetes (liraglutide $1.2 \mathrm{mg}$ or $1.8 \mathrm{mg}$ daily), LEADER liraglutide effect and action in diabetes: evaluation of cardiovascular outcome results (liraglutide, $1.8 \mathrm{mg} \mathrm{QD}$ ), REWIND researching cardiovascular events with a weekly incretin in diabetes (dulaglutide, $0.75 \mathrm{mg}$ or $1.5 \mathrm{mg} \mathrm{QW)}$, SUSTAIN-6 trial to evaluate cardiovascular and other long-term outcomes with semaglutide in subjects with type 2 diabetes (semaglutide, $0.5 \mathrm{mg}$ or $1.0 \mathrm{mg} \mathrm{QW}$ )

a Ongoing

b Includes for exenatide BID

c Conducted for exenatide QW

from various clinical trials are presented in Supplementary Information. Table 12 presents exclusive evidence from key meta-analyses, systematic reviews and pooled studies discussing the impact of GLP-1 RAs on glycaemia.

\section{Body Weight and Composition}

GLP-1 RA decreases gastrointestinal motility and hence increases the time for nutrient absorption. It promotes satiety and resting metabolic rate and lowers plasma concentrations of free fatty acids [97]. It is hypothesised that the weight loss benefits associated with GLP-1 RAs are likely to be due to suppressed appetite, reduced body fat and improved endothelial function [98]. Changes in body weight due to GLP-1 RA administration from various clinical trials are presented in Supplementary Information. Table 13 presents the effect of GLP-1 RAs on body weight and waist 
Table 11 Head-to-head comparison of GLP-1 RAs

\begin{tabular}{|c|c|c|c|c|}
\hline Study & $\begin{array}{l}\text { GLP-1 RAs } \\
\text { compared }\end{array}$ & Number of patients & Duration & Key inferences \\
\hline $\begin{array}{l}\text { Odawara et al. }[70] . \\
\text { Phase } 3 \text {, randomised } \\
\text { controlled trial }\end{array}$ & $\begin{array}{l}\text { Dulaglutide } \\
\text { vs. } \\
\text { liraglutide }\end{array}$ & $\begin{array}{l}\text { Dula }=281, \\
\text { Lira }=141\end{array}$ & 52 weeks & $\begin{array}{l}\text { Dulaglutide demonstrated better } \\
\text { glycaemic control compared to } \\
\text { liraglutide }\end{array}$ \\
\hline $\begin{array}{l}\text { Dungan et al. [71]. } \\
\text { Phase } 3 \text {, randomised, } \\
\text { open-label parallel- } \\
\text { group study } \\
\text { (AWARD-6) }\end{array}$ & $\begin{array}{l}\text { Dulaglutide } \\
\text { vs. } \\
\text { liraglutide }\end{array}$ & $\begin{array}{l}\text { Dula }=299, \\
\text { Lira }=300\end{array}$ & 26 weeks & $\begin{array}{l}\text { Dulaglutide proven non-inferior } \\
\text { to liraglutide for least-squares } \\
\text { mean reduction in HbAlc. } \\
\text { Safety and tolerability profile } \\
\text { were similar to that of liraglutide }\end{array}$ \\
\hline $\begin{array}{l}\text { Ghosal and Sinha [72]. } \\
\text { Retrospective real- } \\
\text { world observational } \\
\text { case note study }\end{array}$ & $\begin{array}{c}\text { Liraglutide vs. } \\
\text { dulaglutide }\end{array}$ & Dula $=30$, Lira $=30$ & 13 weeks & $\begin{array}{l}\text { Addition of GLP-1 RAs to } \\
\text { metformin and SGLT2i had } \\
\text { meaningful impact on all } \\
\text { metabolic parameters. Larger } \\
\text { proportion of patients achieved } \\
\text { HbA1c }<7 \% \text { with liraglutide } \\
\text { compared to dulaglutide }\end{array}$ \\
\hline $\begin{array}{l}\text { Drucker et al. [73]. } \\
\text { Randomised, non- } \\
\text { inferiority study }\end{array}$ & $\begin{array}{l}\text { Exenatide } \\
\text { QW vs. } \\
\text { exenatide } \\
\text { BID }\end{array}$ & $\begin{array}{l}\mathrm{EQW}=148, \\
\mathrm{ExBID}=145\end{array}$ & 30 weeks & $\begin{array}{l}\text { Significantly a greater } \\
\text { improvement in glycaemic } \\
\text { control was demonstrated with } \\
\text { EQW compared to ExBID. The } \\
\text { body weight reduction was } \\
\text { similar between the } 2 \text { groups }\end{array}$ \\
\hline $\begin{array}{l}\text { Blevins et al. [74]. } \\
\text { Randomised, open- } \\
\text { label study }\end{array}$ & $\begin{array}{l}\text { Exenatide } \\
\text { QW vs. } \\
\text { exenatide } \\
\text { BID }\end{array}$ & $\begin{array}{l}\mathrm{EQW}=129, \\
\mathrm{ExBID}=123\end{array}$ & 24 weeks & $\begin{array}{l}\text { EQW demonstrated superior } \\
\text { glycaemic control with less } \\
\text { nausea compared with ExBID }\end{array}$ \\
\hline $\begin{array}{l}\text { Sheu et al. [75]. } \\
\text { Retrospective post hoc } \\
\text { analysis }\end{array}$ & $\begin{array}{l}\text { Exenatide } \\
\text { BID vs. } \\
\text { exenatide } \\
\text { QW }\end{array}$ & $\begin{array}{l}\text { ExBID: Asian, } n=787 \\
\text { White, } n=2223 \\
\text { EQW: Asian, } \\
\begin{array}{l}n=511 ; \text { White, } \\
n=1104\end{array}\end{array}$ & $\begin{array}{l}\text { ExBID: } \\
\text { 12-30 weeks, } \\
\text { EQW: } \\
\text { 24-30 weeks }\end{array}$ & $\begin{array}{l}\text { Asian patients exhibited } \\
\text { significantly greater reductions } \\
\text { in HbAlc and PPBG than } \\
\text { white patients with ExBID }\end{array}$ \\
\hline $\begin{array}{l}\text { Ji et al. [76]. } \\
\text { Randomised, } \\
\text { comparator- } \\
\text { controlled, open-label } \\
\text { study }\end{array}$ & $\begin{array}{l}\text { Exenatide } \\
\text { QW vs. } \\
\text { exenatide } \\
\text { BID }\end{array}$ & $\begin{array}{l}\mathrm{EQW}=340, \\
\mathrm{ExBID}=338\end{array}$ & 26 weeks & $\begin{array}{l}\text { EQW was superior to ExBID in } \\
\text { HbAlc reduction. Weight loss } \\
\text { was greater with ExBID }\end{array}$ \\
\hline
\end{tabular}


Table 11 continued

\begin{tabular}{|c|c|c|c|c|}
\hline Study & $\begin{array}{l}\text { GLP-1 RAs } \\
\text { compared }\end{array}$ & Number of patients & Duration & Key inferences \\
\hline $\begin{array}{l}\text { Buse et al. [77]. } \\
\text { Randomised, parallel- } \\
\text { group, multinational, } \\
\text { open-label trial } \\
\text { (LEAD-6) }\end{array}$ & $\begin{array}{l}\text { Liraglutide vs. } \\
\text { exenatide } \\
\text { BID }\end{array}$ & $\begin{array}{l}\text { Lira }=233 \\
\quad \text { ExBID }=231\end{array}$ & 26 weeks & $\begin{array}{l}\text { Significantly greater improvement } \\
\text { in glycaemic control was } \\
\text { observed with liraglutide } \\
\text { compared to ExBID }\end{array}$ \\
\hline $\begin{array}{l}\text { Buse et al. [78]. Open- } \\
\text { label, randomised, } \\
\text { parallel-group study } \\
\text { (DURATION-6) }\end{array}$ & $\begin{array}{l}\text { Exenatide } \\
\text { QW vs. } \\
\text { liraglutide } \\
\text { QD }\end{array}$ & $\begin{aligned} \mathrm{EQW} & =461, \\
\text { Lira } & =450\end{aligned}$ & 26 weeks & $\begin{array}{l}\text { A greater reduction in } \mathrm{HbAlc} \text { was } \\
\text { observed with liraglutide } \\
\text { compared to EQW }\end{array}$ \\
\hline $\begin{array}{l}\text { Feher et al. [79]. Real- } \\
\text { world, observational } \\
\text { study }\end{array}$ & $\begin{array}{l}\text { Liraglutide } \\
\text { QD vs. } \\
\text { lixisenatide } \\
\text { QD }\end{array}$ & Lira $=579$, Lixi $=213$ & 12 months & $\begin{array}{l}\text { Treatment with liraglutide } \\
\text { demonstrated better glycaemic } \\
\text { control compared to lixisenatide }\end{array}$ \\
\hline $\begin{array}{l}\text { Nauck et al. [80]. } \\
\text { Randomised, parallel- } \\
\text { group, open-label trial }\end{array}$ & $\begin{array}{l}\text { Liraglutide } \\
\text { QD vs. } \\
\text { lixisenatide } \\
\text { QD }\end{array}$ & Lira $=202$, Lixi $=202$ & 26 weeks & $\begin{array}{l}\text { Liraglutide demonstrated to be } \\
\text { more effective in improving } \\
\text { glycaemic control compared to } \\
\text { lixisenatide }\end{array}$ \\
\hline $\begin{array}{l}\text { Stryker et al. [81]. Real- } \\
\text { world observational } \\
\text { study }\end{array}$ & $\begin{array}{l}\text { Exenatide } \\
\text { QW vs. } \\
\text { liraglutide } \\
\text { QD }\end{array}$ & $\mathrm{EQW}=75$, Lira $=75$ & 12 months & $\begin{array}{l}\text { More subjects in the EQW arm } \\
\text { achieved an HbAlc }<7 \% \\
\text { compared to liraglutide arm; } \\
\text { however, the baseline HbAlc } \\
\text { was lower for the EQW arm } \\
(7.9 \%) \text { compared to liraglutide } \\
\text { arm }(8.4 \%)\end{array}$ \\
\hline $\begin{array}{l}\text { McAdam-Marx et al. } \\
\text { [82]. Retrospective } \\
\text { cohort study }\end{array}$ & $\begin{array}{l}\text { Exenatide } \\
\text { QW vs. } \\
\text { liraglutide } \\
\text { QD }\end{array}$ & $\begin{aligned} \text { EQW } & =808, \\
\text { Lira } & =4333\end{aligned}$ & 1 year & $\begin{array}{c}\text { HbAlc and weight reductions } \\
\text { were similar in EQW- and } \\
\text { liraglutide-treated patients }\end{array}$ \\
\hline $\begin{array}{l}\text { Rosenstock et al. [83]. } \\
\text { Randomised, open- } \\
\text { label, active-controlled } \\
\text { study }\end{array}$ & $\begin{array}{l}\text { Lixisenatide } \\
\text { vs. } \\
\text { exenatide } \\
\text { BID }\end{array}$ & $\begin{array}{l}\text { Lixi }=318, \\
\text { ExBID }=316\end{array}$ & 24 weeks & $\begin{array}{l}\text { Lixisenatide demonstrated to be } \\
\text { non-inferior in HbAlc } \\
\text { reduction compared to ExBID. } \\
\text { Slightly lower mean weight loss, } \\
\text { lower incidence of } \\
\text { hypoglycaemia and better } \\
\text { gastrointestinal tolerability were } \\
\text { demonstrated with lixisenatide } \\
\text { compared with ExBID }\end{array}$ \\
\hline
\end{tabular}


Table 11 continued

\begin{tabular}{|c|c|c|c|c|}
\hline Study & $\begin{array}{l}\text { GLP-1 RAs } \\
\text { compared }\end{array}$ & Number of patients & Duration & Key inferences \\
\hline $\begin{array}{l}\text { Ahmann et al. [84]. } \\
\text { Phase 3a, open-label, } \\
\text { parallel-group } \\
\text { randomised controlled } \\
\text { trial }\end{array}$ & $\begin{array}{l}\text { Semaglutide } \\
\text { QW vs. } \\
\text { exenatide } \\
\text { QW }\end{array}$ & $\begin{array}{l}\text { Sema }=404, \\
E Q W=405\end{array}$ & 56 weeks & $\begin{array}{l}\text { Semaglutide was superior to EQW } \\
\text { in improving glycaemic control } \\
\text { and reducing body weight }\end{array}$ \\
\hline
\end{tabular}

Refer to Supplementary Information for changes in HbAlc and body weight and information on adverse events AWARD assessment of weekly administration of LY2189265 in diabetes (dulaglutide, $0.75 \mathrm{mg}$ or $1.5 \mathrm{mg} \mathrm{QW}$ ), Dula dulaglutide, ExBID exenatide BID, EQW exenatide QW, GLP-1 RA glucagon-like peptide-1 receptor agonist, HbAlc glycated haemoglobin, Lira liraglutide, Lixi lixisenatide, PPBG postprandial blood glucose, Sema semaglutide, SGLT2i sodium-glucose co-transporter-2 inhibitor

circumference from meta-analyses, systematic reviews and pooled studies. In addition, studies comparing the treatment with GLP-1 RA, SGLT2i and bariatric surgery are also presented in Table 13.

\section{Cardiovascular Health}

GLP-1 RAs have been reported to be beneficial for cardiovascular health in patients with T2DM as these drugs aid in controlling cardiovascular (CV) risk factors such as hyperglycaemia, dyslipidaemia, weight gain and arterial hypertension (Tables 14, 15). Evidence also suggests that these drugs may have beneficial effects on endothelial function, coronary ischaemia and heart failure [117]. Several cardiovascular outcome trials (CVOTs) have been conducted or are being conducted to elucidate CV safety of GLP-1 RAs in patients. The key results from CVOTs for various GLP-1 RAs are presented in Table 16. In addition, key systematic reviews and metaanalyses involving CVOTs and other studies discussing CV outcomes with the use of GLP-1 RA are presented in Table 17.

$\mathrm{CV}$ protection has been demonstrated with liraglutide (The Liraglutide Effect and Action in Diabetes: Evaluation of Cardiovascular Outcome Results trial; LEADER), semaglutide (Semaglutide in Subjects with Type 2 Diabetes; SUSTAIN-6) and albiglutide (HARMONY). The effect was neutral with exenatide LAR (Exenatide Study of Cardiovascular Event Lowering Trial; EXSCEL) and lixisenatide (Evaluation of LIXisenatide in
Acute coronary syndrome; ELIXA) [146]. The result of Researching cardiovascular Events with a Weekly INcretin in Diabetes (REWIND) trial, which is reported to be the longest among the CVOT trials, is due to be published in the near future and may bring about new dimensions to CV health in patients with T2DM $[147,148]$.

\section{Renal Health}

GLP-1 RAs have both direct and indirect renoprotective effects. GLP-1 RAs directly exert their renoprotective effects by reducing the markers involved in renal hypoxia and those involved in the activation of the renin-angiotensin system. They also aid in preventing glomerular atherosclerosis. Indirect renoprotective effects include improved glucose control, BP and weight loss. Although available evidence supports reduction of albuminuria in patients treated with GLP-1 RAs, clear evidence for its effects on renal outcomes is still lacking. This is primarily because very few patients with advanced renal disease receive GLP-1 RA as a result of its poor tolerability in this patient subset [149].

A more detailed discussion on the effects of each GLP-1 RA on renal health is presented with clinical evidence in Table 18.

\section{Hepatic Health}

GLP-1 RAs may play a role in protecting both lean and fatty livers from ischaemic injury by 


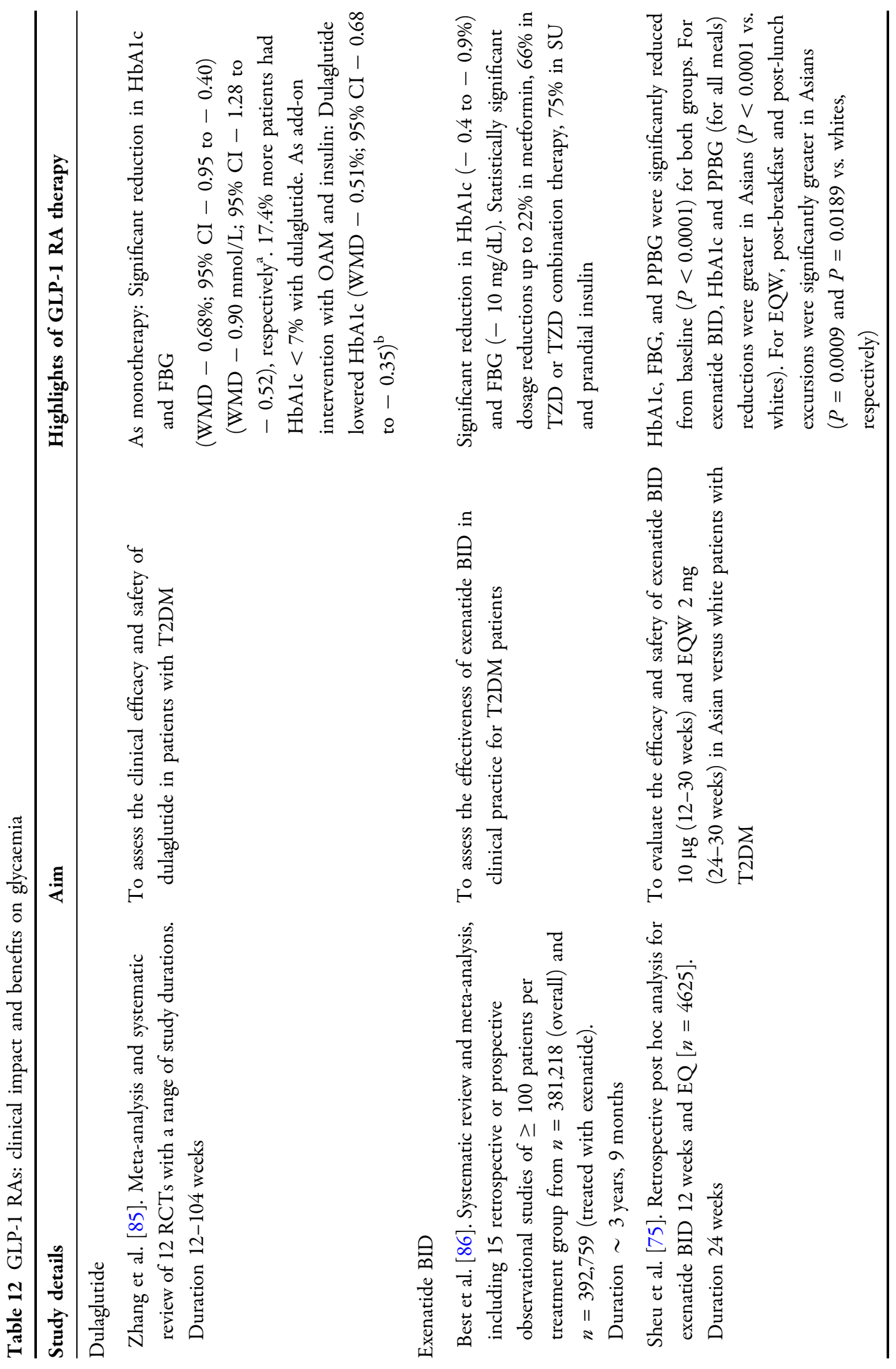









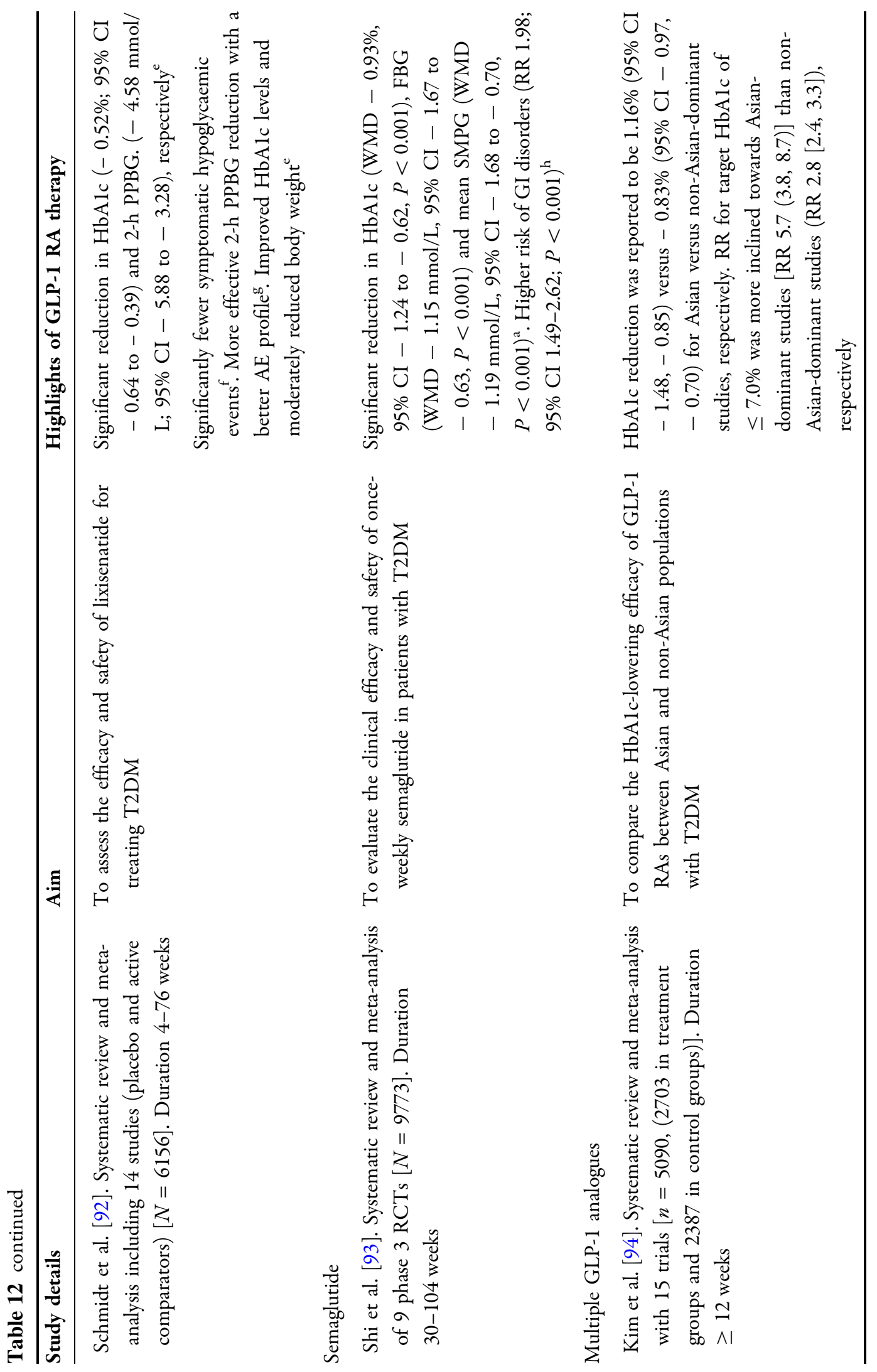




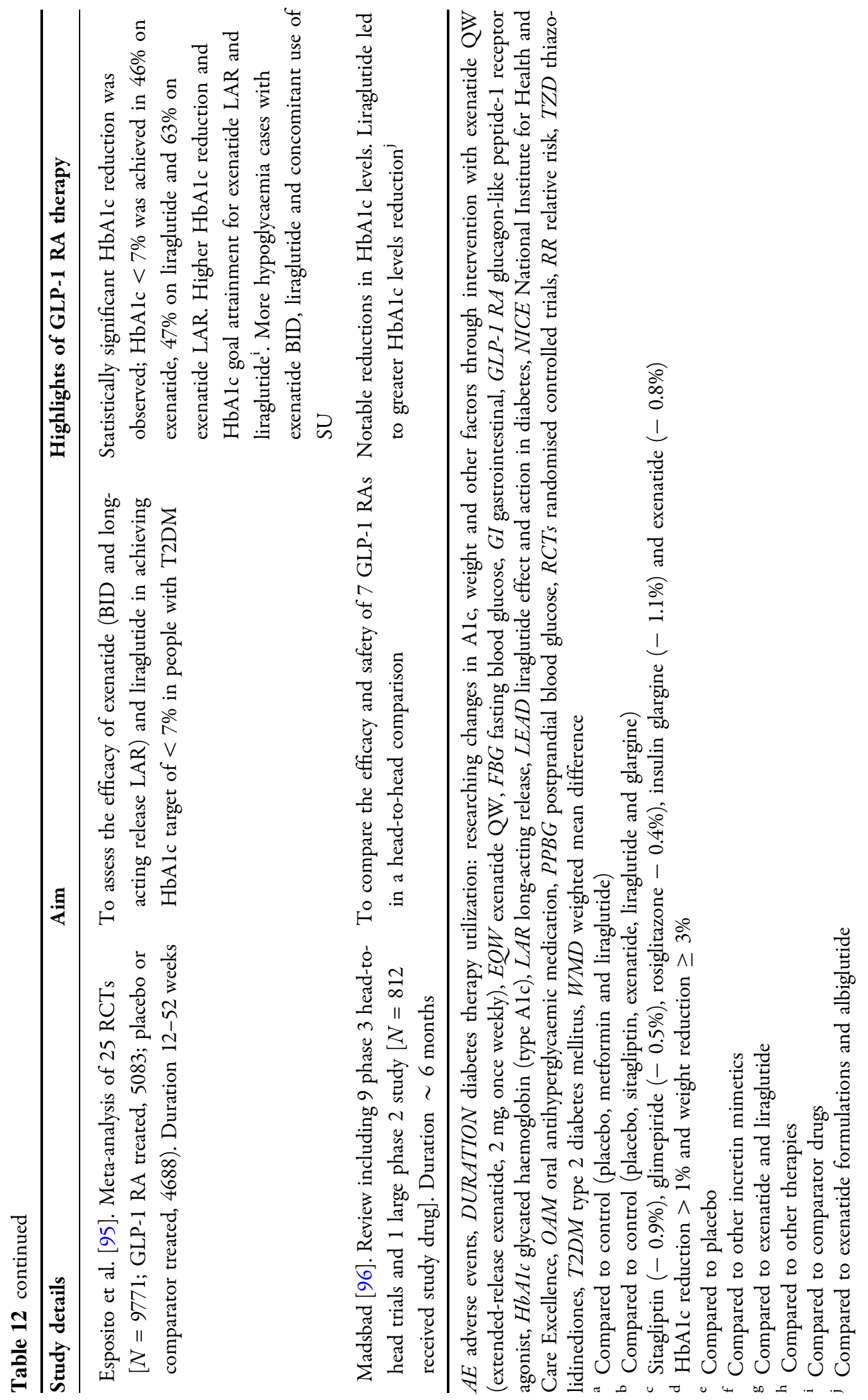




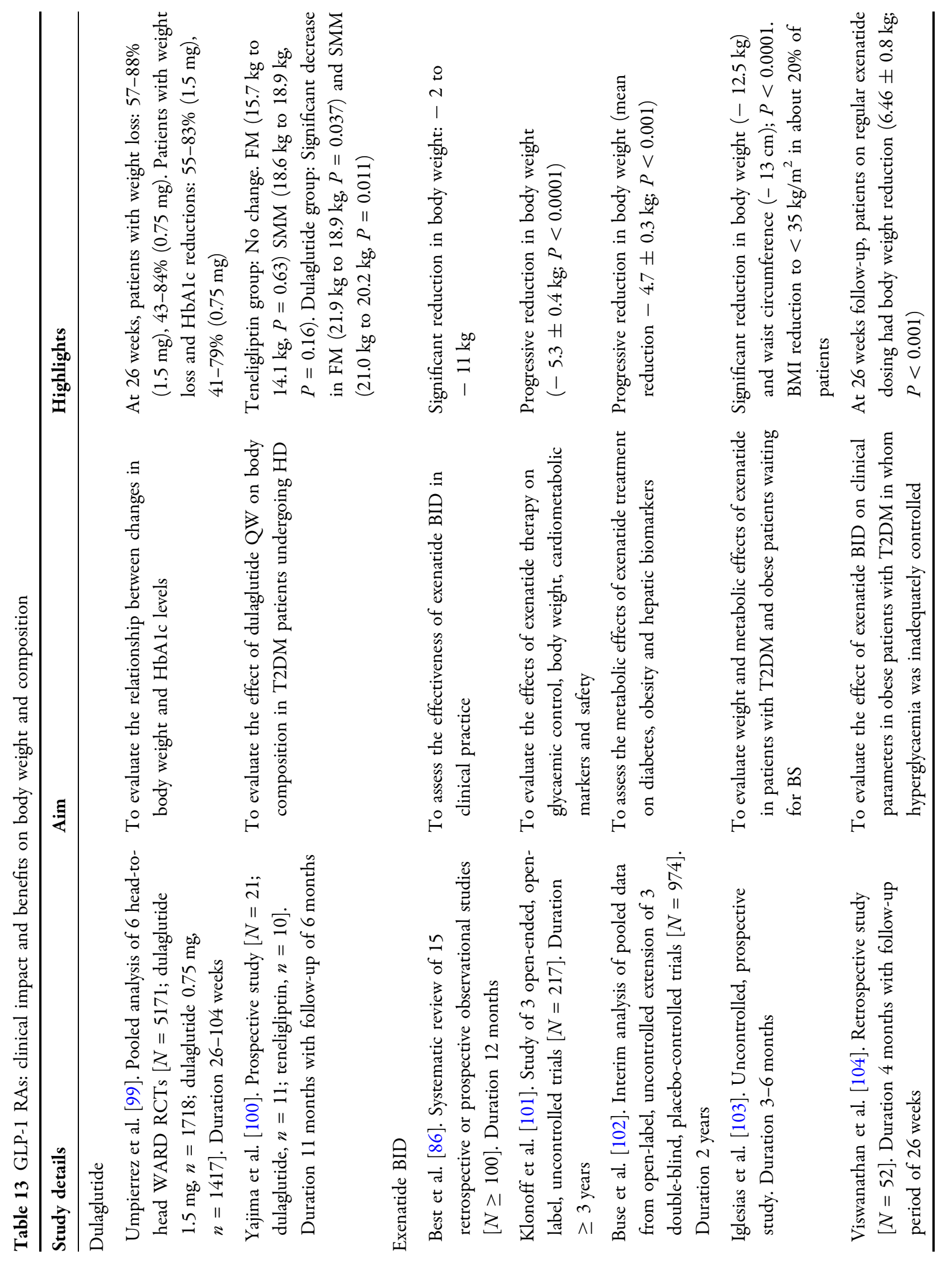




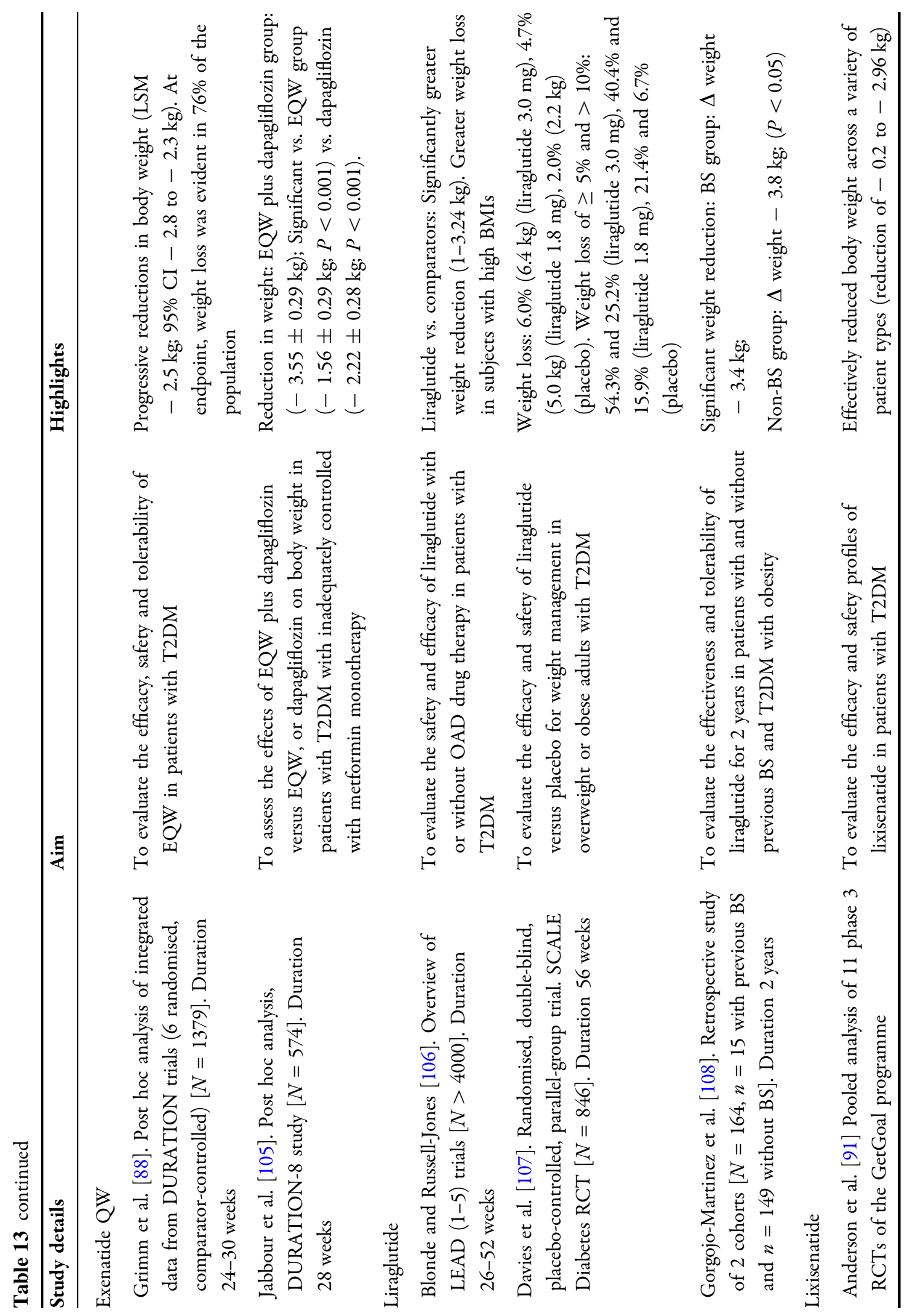




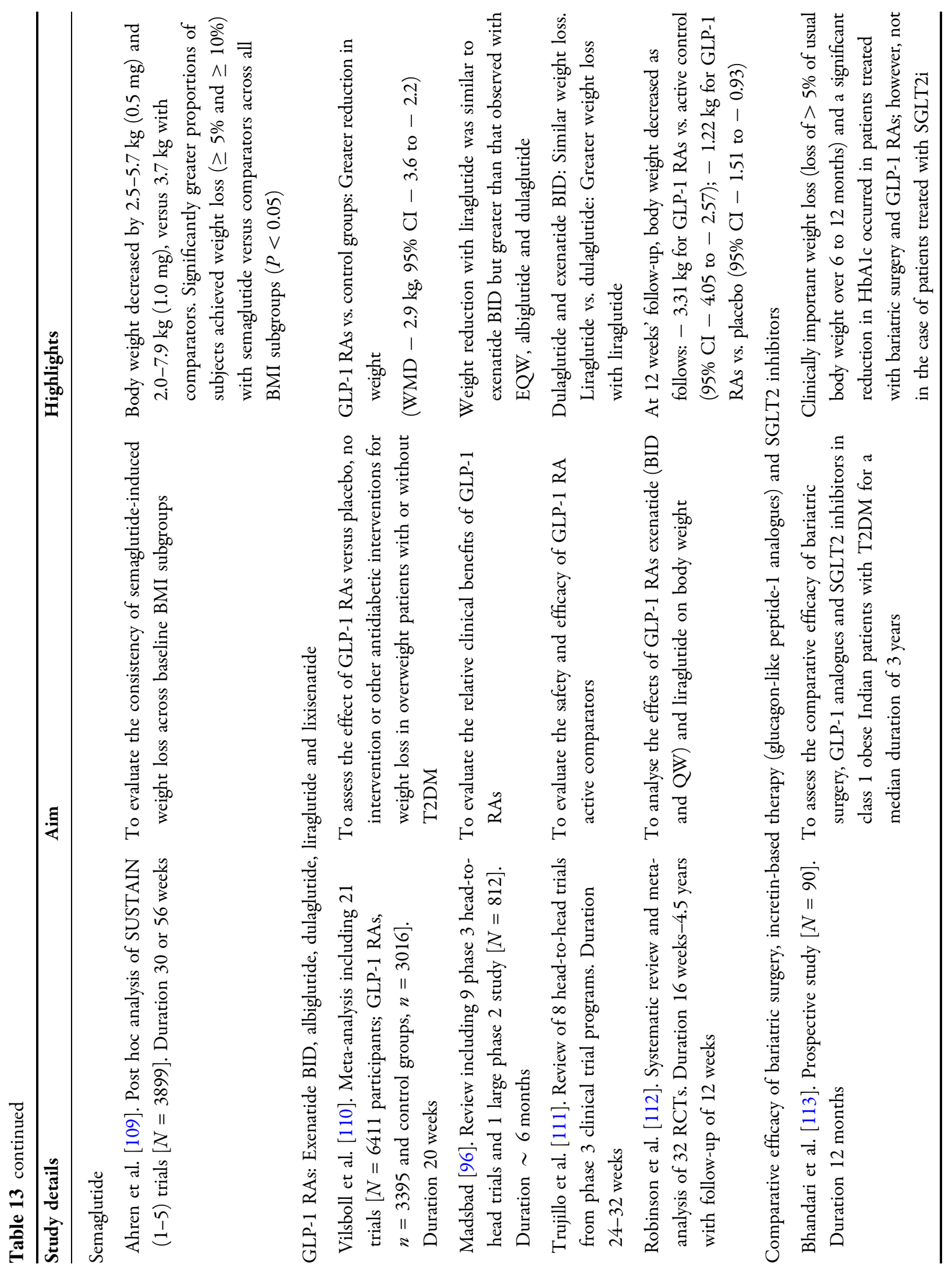




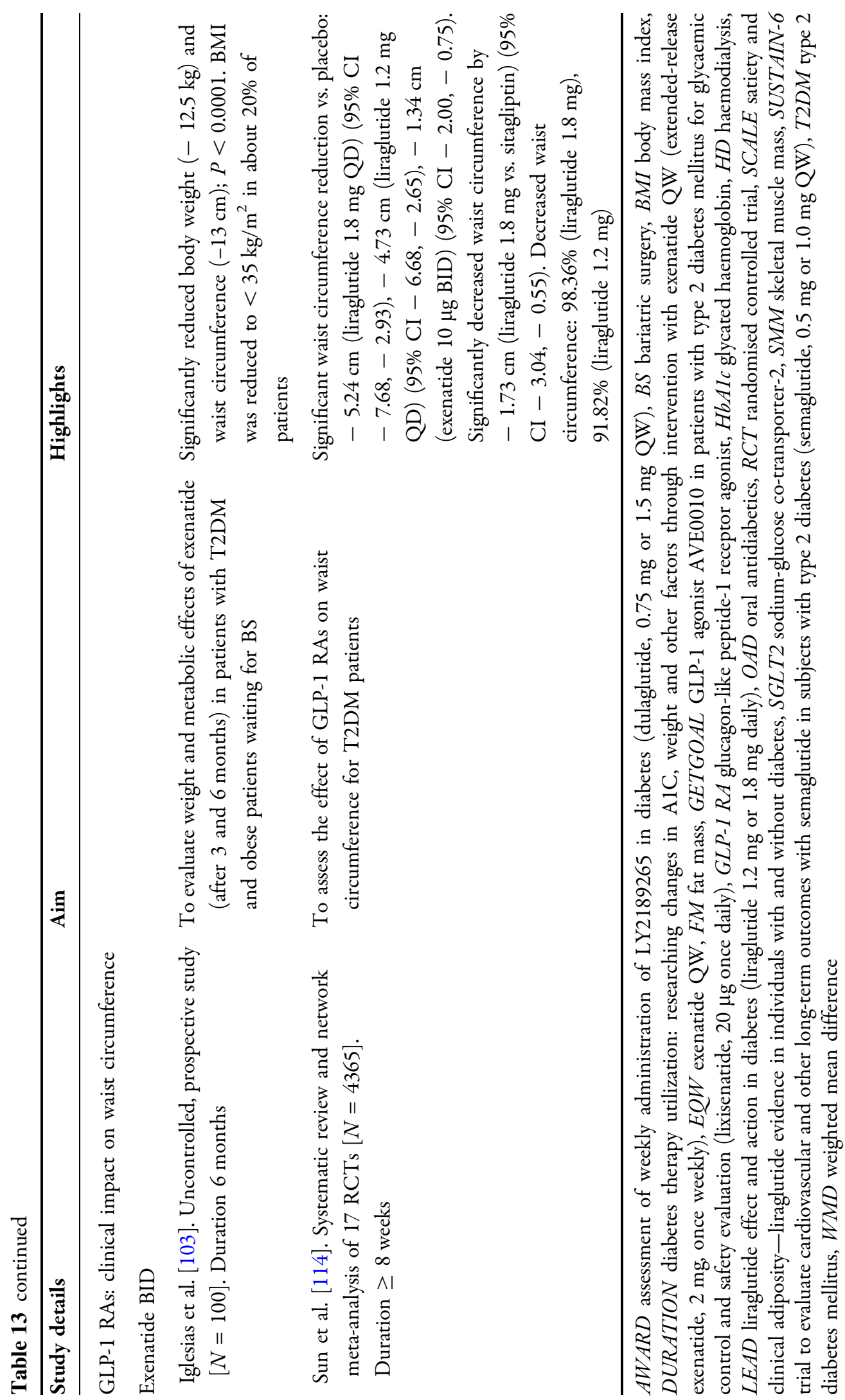




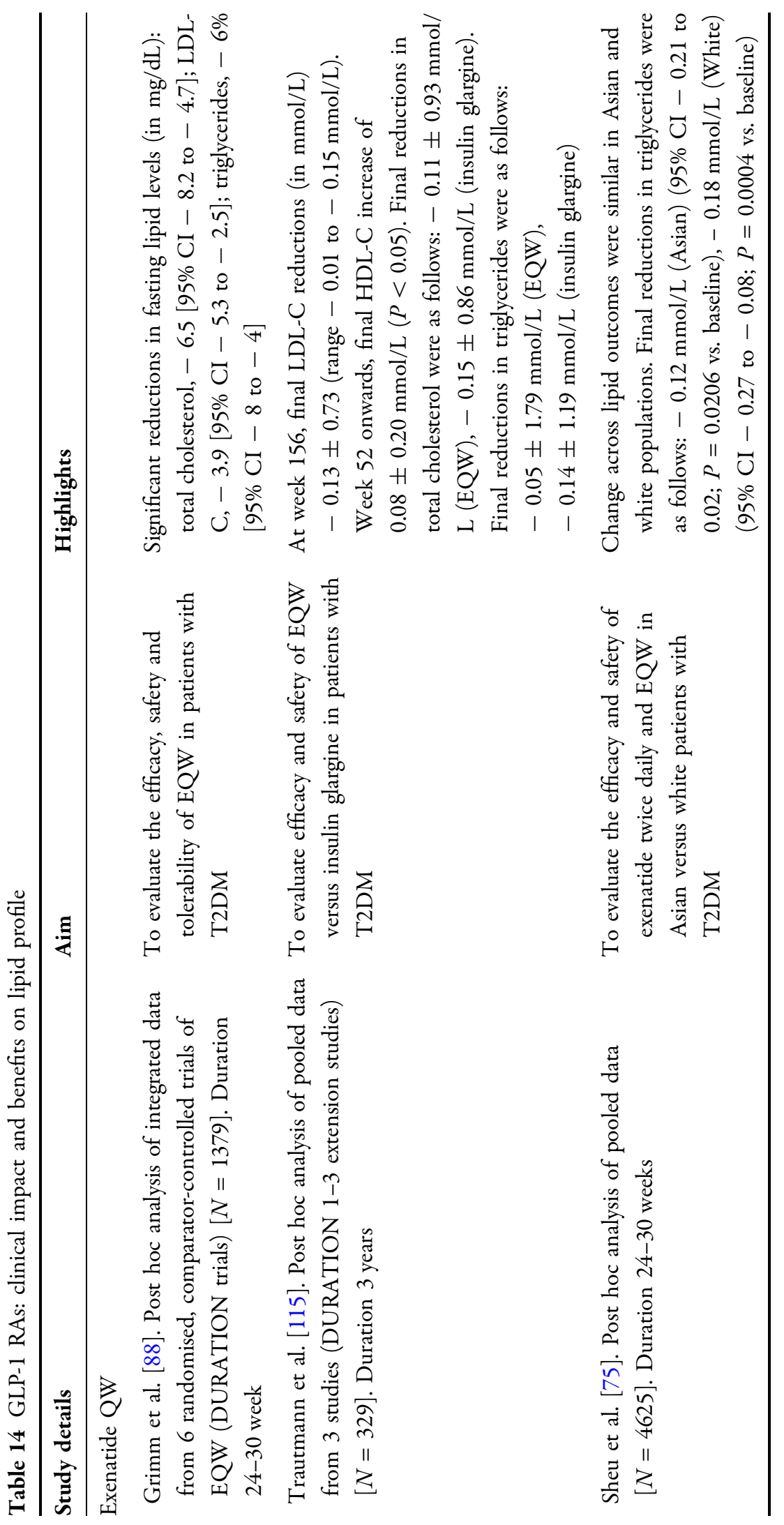




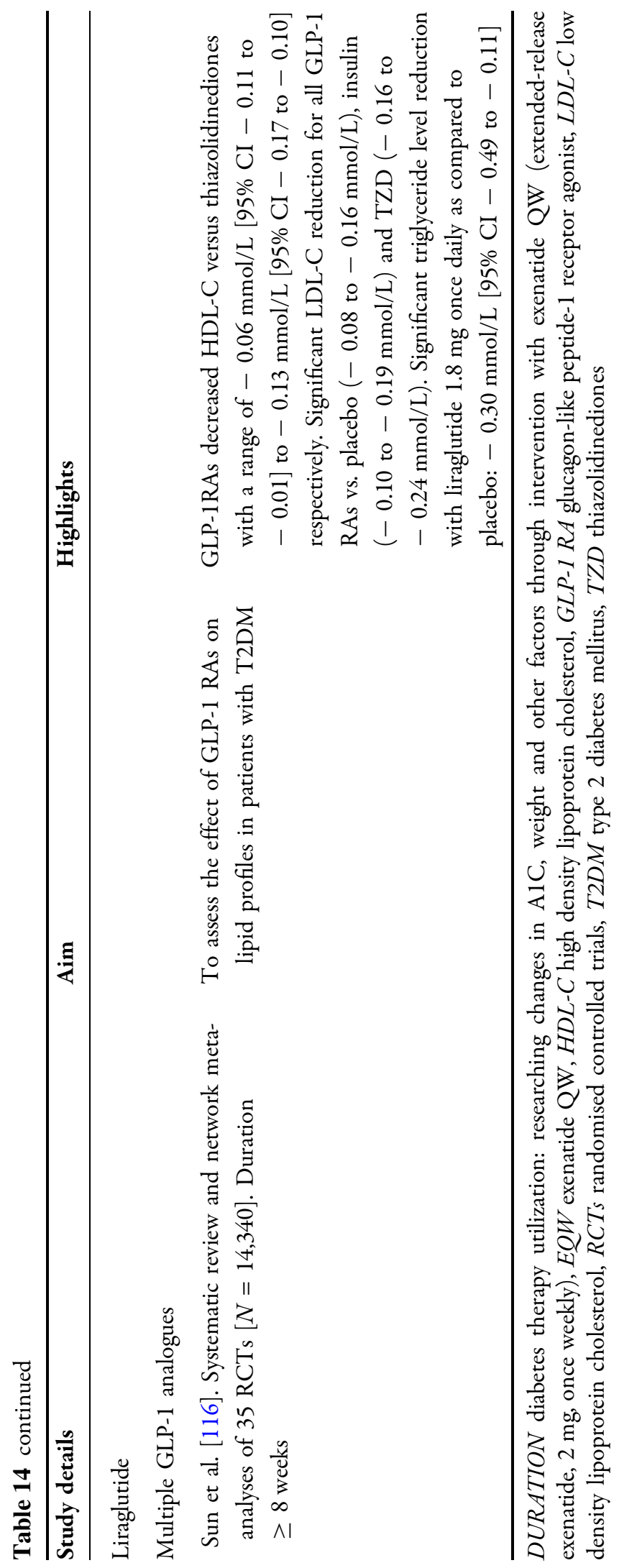




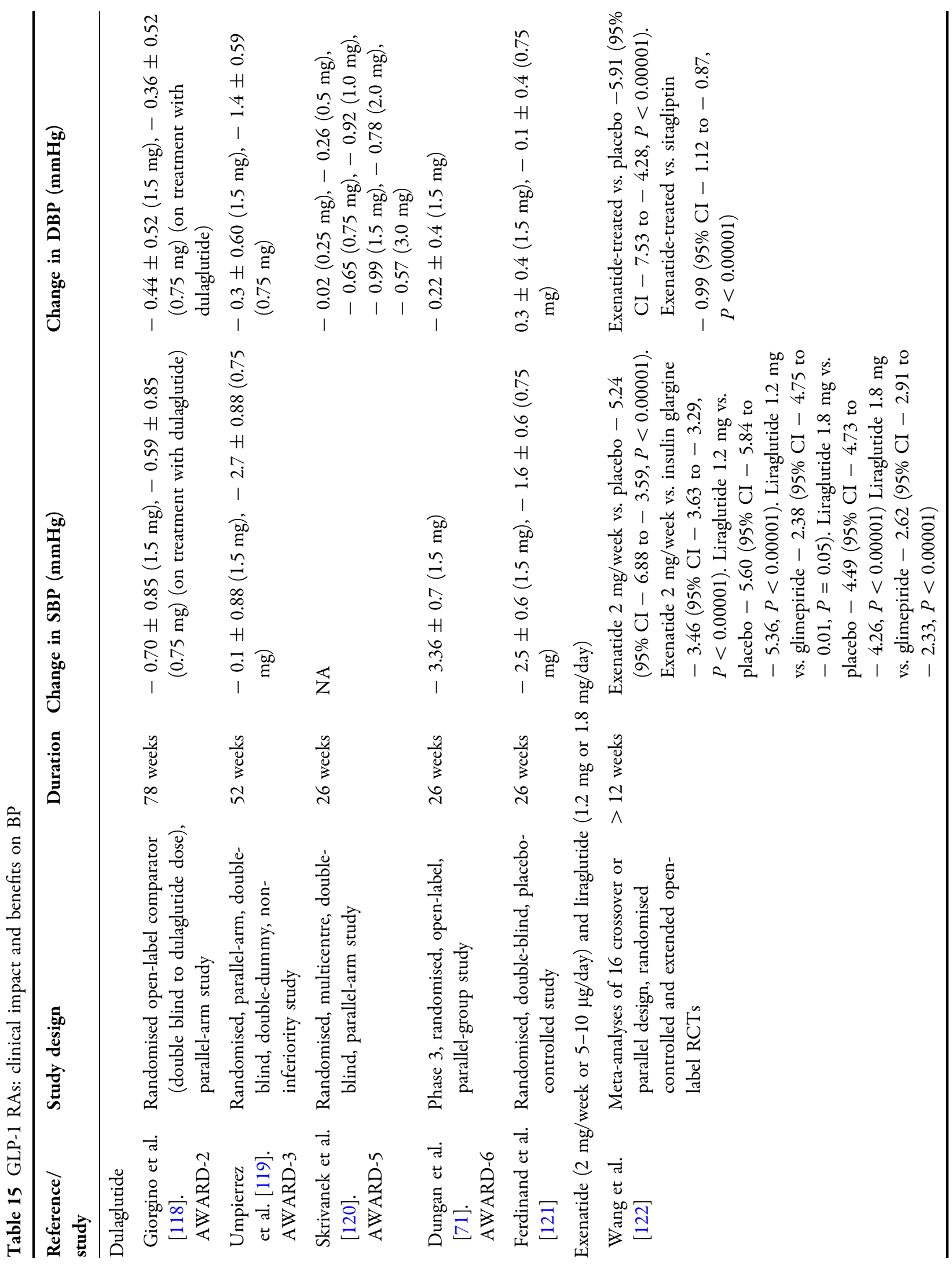




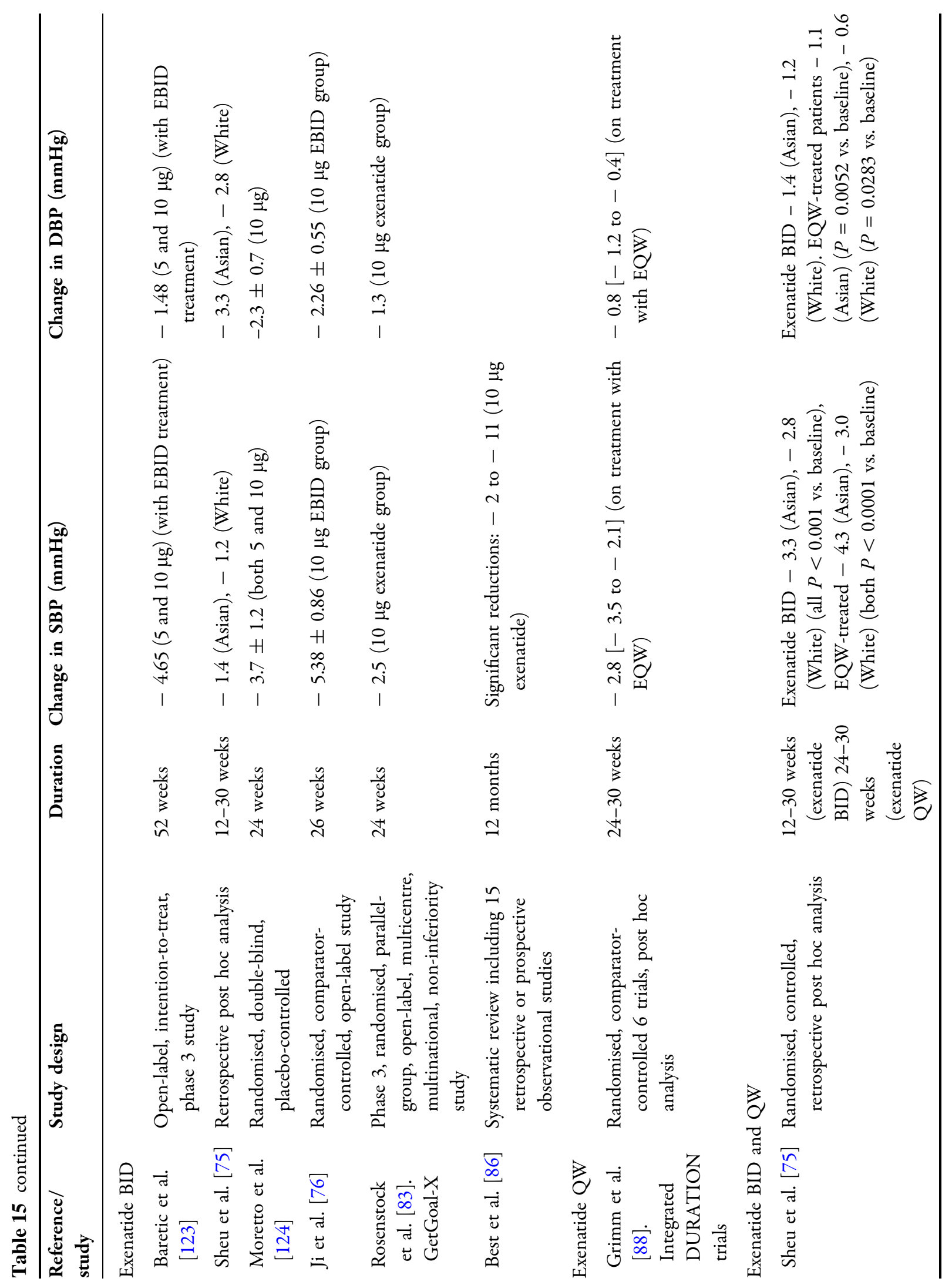









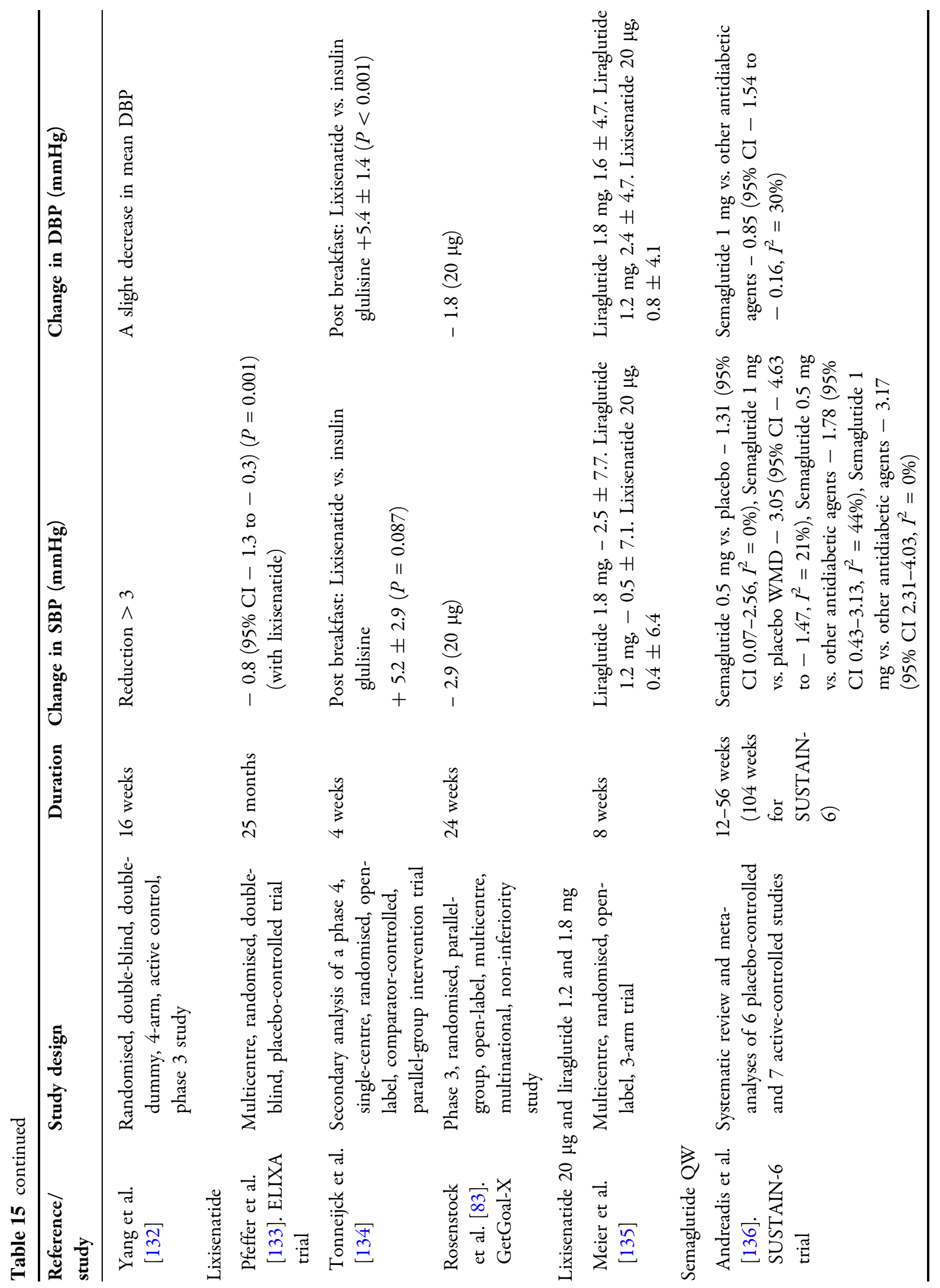




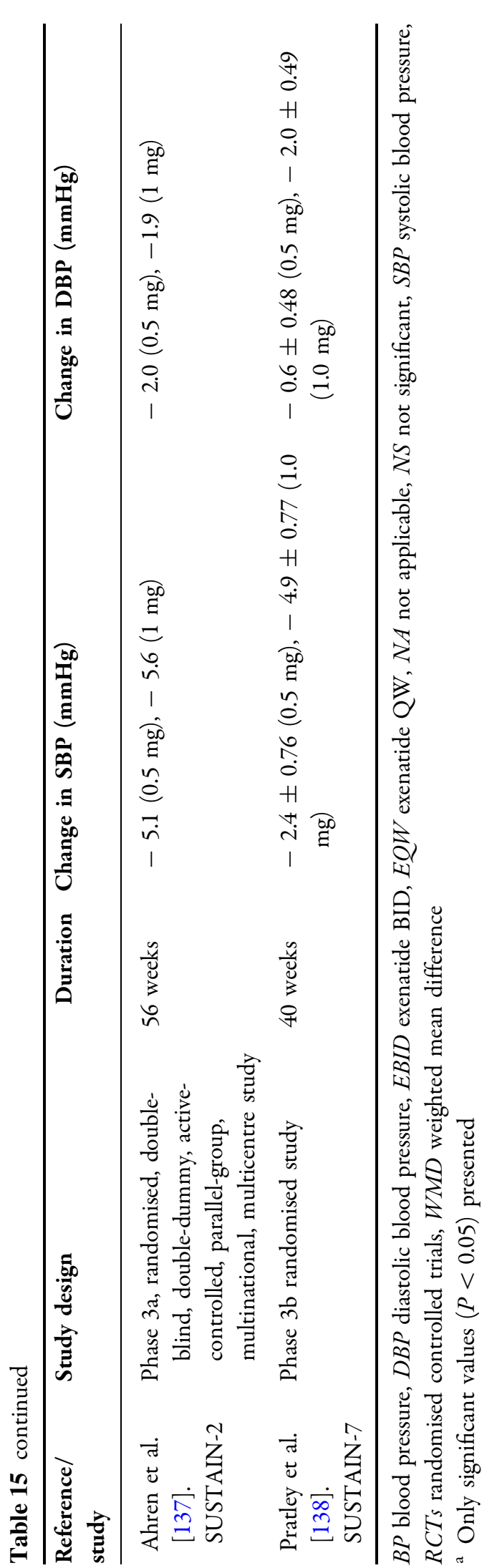

inhibiting cell death and stimulating lipolysis $[162$, 163]. GLP-1 RAs can reduce hepatic steatosis and improve survival by enhancing the unfolded protein response by promoting macroautophagy. In addition, they improve insulin resistance and insulin sensitivity to prevent the progression of non-alcoholic fatty liver disease (NAFLD) [164-167]. The unique ability of GLP-1 RAs to promote weight loss, improve glycaemic control and potentially reverse hepatocyte injury, liver inflammation, and liver fibrosis makes them a novel and attractive therapeutic option for the treatment of non-alcoholic steatohepatitis (NASH) [168]. A literature review evaluating the safety and efficacy of medications for the treatment of NASH in patients with T2DM reported favourable outcomes associated with the use of GLP-1 RAs with respect to reducing transaminases and steatosis along with improvements in insulin sensitivity and weight loss [169]. Currently, there is limited clinical experience with GLP-1 RAs in patients with severe hepatic impairment [170]. The beneficial effects of GLP-1 RAs on hepatic health are presented with clinical evidence in Table 19.

\section{Pancreatitis}

GLP-1 RAs are recommended to be used with caution/not used in patients with a familial/ personal history of pancreatitis depending on the respective prescribing information [178]. A few clinical studies and meta-analyses focussing on pancreatitis are presented in Table 20.

\section{Cholelithiasis}

GLP-1 RAs are known to pose a significantly increased risk of cholelithiasis [183]. The key clinical evidence on cholelithiasis associated with GLP-1 RAs is presented in Table 21.

\section{GLP-1 RAS USE IN COMPLICATED DIABETES AND SPECIAL POPULATIONS}

GLP-1 RA use in patients with cardiovascular complications, renal impairment and hepatic impairment along with their use in elderly, 
Table 16 Baseline characteristics and key results of CVOTs for GLP-1 RAs

\begin{tabular}{|c|c|c|c|c|c|}
\hline $\begin{array}{l}\text { Trial } \\
\text { Drug tested }\end{array}$ & $\begin{array}{l}\text { EXSCEL } \\
\text { Exenatide } \\
(Q W) \\
{[139,140]}\end{array}$ & $\begin{array}{l}\text { LEADER } \\
\text { Liraglutide } \\
{[139,140]}\end{array}$ & $\begin{array}{l}\text { ELIXA } \\
\text { Lixisenatide } \\
{[139,140]}\end{array}$ & $\begin{array}{l}\text { SUSTAIN-6 } \\
\text { Semaglutide } \\
{[139,140]}\end{array}$ & $\begin{array}{l}\text { HARMONY } \\
\text { Albiglutide } \\
{[141,142]}\end{array}$ \\
\hline \multicolumn{6}{|l|}{ Baseline characteristics } \\
\hline Dose & $\begin{array}{l}\text { Up to } 2 \mathrm{mg} \\
\text { weekly }\end{array}$ & $\begin{array}{l}\text { Up to } \\
1.8 \mathrm{mg} / \text { day }\end{array}$ & Up to $20 \mu \mathrm{g} /$ day & $\begin{array}{l}0.5 \text { or } 1 \mathrm{mg} \\
\text { weekly }\end{array}$ & $30-50 \mathrm{mg} /$ week \\
\hline No. of patients & 14,752 & 9340 & 6068 & 3297 & 9463 \\
\hline Mean age (years) & 61 & 64.3 & 59.9 & 64.6 & 64.1 \\
\hline Women (\%) & 38 & 36 & 31 & 39 & 31 \\
\hline Mean BMI $\left(\mathrm{kg} / \mathrm{m}^{2}\right)$ & 32.7 & 32.5 & 30.1 & 32.8 & 32.3 \\
\hline Mean HbAlc (\%) & 8.1 & 8.7 & 7.7 & 8.7 & 8.7 \\
\hline $\begin{array}{l}\text { Mean duration of } \\
\text { diabetes (years) }\end{array}$ & 13.1 & 12.8 & 9.2 & 13.9 & 13.8 \\
\hline Prior CVD (\%) & 73 & 81.3 & 100 & 83 & $\mathrm{NA}^{\mathrm{a}}$ \\
\hline Heart failure (\%) & 16 & 17 & 22.5 & 24 & 20.2 \\
\hline $\mathrm{SBP}(\mathrm{mmHg})$ & 136 & 138 & 130 & 136 & 134.7 \\
\hline $\begin{array}{l}\mathrm{eGFR}<60 \mathrm{~mL} / \mathrm{min} / \\
1.73 \mathrm{~m}^{2}(\%)\end{array}$ & 21.3 & 24 & 22 & 28.5 & 10.6 \\
\hline Comparator & $\begin{array}{l}\text { Placebo and } \\
\text { standard of } \\
\text { care }\end{array}$ & $\begin{array}{l}\text { Placebo and } \\
\text { standard of } \\
\text { care }\end{array}$ & $\begin{array}{l}\text { Placebo and } \\
\text { standard of } \\
\text { care }\end{array}$ & $\begin{array}{l}\text { Placebo and } \\
\text { standard of } \\
\text { care }\end{array}$ & $\begin{array}{l}\text { Placebo and } \\
\text { standard of } \\
\text { care }\end{array}$ \\
\hline $\begin{array}{l}\text { Median follow-up } \\
\text { (years) }\end{array}$ & 3.2 & 3.8 & 2.1 & 2.1 & 1.5 \\
\hline \multicolumn{6}{|l|}{ Results } \\
\hline $\begin{array}{l}\text { No. of primary events } \\
\text { observed }\end{array}$ & 1744 & 1302 & 844 & 254 & 338 \\
\hline $\begin{array}{l}\text { Non-inferiority for } \\
\text { MACE demonstrated? }\end{array}$ & Yes & Yes & Yes & Yes & Yes \\
\hline Superiority for $\mathrm{MACE}^{\mathrm{b}}$ & No difference & $\begin{array}{l}\text { Superior }(13 \% \\
\text { reduction) }\end{array}$ & No difference & $\begin{array}{l}\text { Superior }(26 \% \\
\text { reduction })^{c}\end{array}$ & Superior \\
\hline $\mathrm{CV}$ death reduced? & No & Yes & No & No & No \\
\hline $\begin{array}{l}\text { All-cause mortality } \\
\text { reduced? }\end{array}$ & Yes & Yes & No & No & No \\
\hline $\begin{array}{l}\text { Difference in HbAlc (\% } \\
\text { units) }\end{array}$ & 0.27 & 0.4 & 1.0 & 0.53 & 0.63 \\
\hline
\end{tabular}


Table 16 continued

\begin{tabular}{llllll}
\hline $\begin{array}{l}\text { Trial } \\
\text { Drug tested }\end{array}$ & $\begin{array}{l}\text { EXSCEL } \\
\text { Exenatide } \\
(\mathbf{Q W})\end{array}$ & $\begin{array}{l}\text { LEADER } \\
\text { Liraglutide } \\
{[\mathbf{1 3 9}, \mathbf{1 4 0}]}\end{array}$ & $\begin{array}{l}\text { ELIXA } \\
\text { Lixisenatide } \\
{[139,140]}\end{array}$ & $\begin{array}{l}\text { SUSTAIN-6 } \\
\text { Semaglutide } \\
{[139,140]}\end{array}$ & $\begin{array}{l}\text { HARMONY } \\
\text { Albiglutide } \\
{[141,142]}\end{array}$ \\
\hline $\begin{array}{l}\text { Mean reduction in } \\
\text { weight }(\mathrm{kg})\end{array}$ & 0.7 & 2.3 & 4.3 & 1.27 & 0.83 \\
\hline
\end{tabular}

Cited references to be visited for detailed information

$B M I$ body mass index, $C V$ cardiovascular, $C V D$ cardiovascular disease, CVOT cardiovascular outcome trials, $e G F R$ estimated glomerular filtration rate, $E L I X A$ evaluation of lixisenatide in acute coronary syndrome (lixisenatide, maximum dose $20 \mu \mathrm{g}$ per day), EXSCEL exenatide study of cardiovascular event lowering trial (exenatide QW, $2 \mathrm{mg}$ ), GLP-1 RA glucagon-like peptide-1 receptor agonist, $H A R M O N Y$ trial to evaluate the effect of albiglutide on major cardiovascular events in patients with type 2 diabetes mellitus, HbAlc glycated haemoglobin, $L E A D E R$ liraglutide effect and action in diabetes: evaluation of cardiovascular outcome results (liraglutide, $1.8 \mathrm{mg}$ QD), $M A C E$ major adverse cardiovascular events, $N A$ not available, $S B P$ systolic blood pressure, SUSTAIN-6 trial to evaluate cardiovascular and other long-term outcomes with semaglutide in subjects with type 2 diabetes (semaglutide, $0.5 \mathrm{mg}$ or $1.0 \mathrm{mg} \mathrm{QW}$ )

a Prior coronary artery disease, $70.5 \%$; peripheral arterial disease, $25.0 \%$; stroke, $17.7 \%$; heart failure, $20.2 \%$

b Compared to placebo and standard of care

c The comparison was not pre-specified and not to be used for regulatory purposes

pregnant and lactating women is discussed here along with relevant clinical evidence. Special situations including fasting have been discussed.

\section{GLP-1 RAs Use in Complicated Diabetes}

\section{Patients with Cardiovascular Complications} Patients with T2DM are at a higher risk of developing CVD, which in turn is recognised to be the leading cause of death in patients with diabetes [184]. Although the use of these agents is encouraged in patients with asymptomatic and stable CAD, there is no clear evidence regarding their usage in acute myocardial infarction. Hence, factors to be considered before/during the use of GLP-1 analogues in such cases could be a pragmatic approach based on prescribing information, available clinical evidence and clinical sense of physicians [185]. The CV safety of GLP-1 RAs was presented in previous sections.

\section{Patients with Renal Impairment}

Exenatide and lixisenatide are predominantly cleared by the kidney. Exenatide dosage is not recommended to be increased in patients with an eGFR of $30-60 \mathrm{~mL} / \mathrm{min} / 1.73 \mathrm{~m}^{2}$. Both exenatide and lixisenatide are contraindicated in patients with eGFR $<30 \mathrm{~mL} / \mathrm{min} / 1.73 \mathrm{~m}^{2}$. Although clearance of liraglutide and dulaglutide is predominantly hepatic, administration of these drugs in patients with renal impairment needs to be considered with caution. This is largely because of the GI side effects and risk of associated volume depletion in case of chronic kidney disease (CKD) and brittle renal haemodynamics [149]. The renal safety of GLP1 RAs has been discussed in previous sections.

Recommendations for the usage of GLP-1 RA in T2DM patients with renal impairment (as per the European label) are presented in Table 22.

\section{Patients with Hepatic Impairment}

Elimination of GLP-1 RAs does not occur mainly by hepatic metabolism. As discussed in the previous sections, exenatide is primarily eliminated by the kidneys, whereas liraglutide and dulaglutide are metabolised endogenously into their component amino acids by general protein catabolism pathways. No specific organ is presumed to be the major route of elimination for GLP-1 RAs. It is important to note that there is limited information available on the safety and efficacy of GLP-1 RAs in patients with 
Table 17 Key studies reporting cardiovascular outcomes with GLP-1 RA therapy

\begin{tabular}{|c|c|c|}
\hline Study details & Aim & Highlights \\
\hline \multicolumn{3}{|l|}{ Dulaglutide } \\
\hline $\begin{array}{l}\text { Ferdinand et al. [143]. Meta-analysis } \\
\text { of } 9 \text { randomised safety and efficacy } \\
\text { trials }[N=6010 \text {; dulaglutide, } 3885 \text {; } \\
\text { comparator therapy active or placebo, } \\
2125]\end{array}$ & $\begin{array}{l}\text { To evaluate the CV risk in patients } \\
\text { with T2DM treated with dulaglutide }\end{array}$ & $\begin{array}{l}\text { Patients who experienced primary } \\
\text { 4-component MACE: } 26 \text { (0.67\%) for } \\
\text { dulaglutide vs. } 25 \text { (1.18\%) for } \\
\text { comparator (HR 0.57; adjusted } \\
\text { 98.02\% CI 0.30-1.10). No } \\
\text { significant difference between the } \\
\text { groups for 3-component MACE, } \\
\text { 6-component MACE and all-cause } \\
\text { mortality, (HR < } 1.0 \text { for all). } \\
\text { Dulaglutide does not increase major } \\
\text { CV events risk in T2DM patients }\end{array}$ \\
\hline
\end{tabular}

Exenatide BID

Ratner et al. [144]. Pooled analysis of To evaluate the CV safety of exenatide retrospectively examined data from RCTs ( 8 blinded, 4 open label); [Exenatide BID $(n=2316)$, pooled comparator (placebo, $n=971$; or insulin, $n=658)$ ] BID versus pooled comparator or insulin, in patients with T2DM
Exenatide use did not increase CV risk. Primary MACE RR 0.7, 95\% CI $0.38-1.31$ (calculated by the Mantel-Haenszel method as compared to pooled comparators)

Multiple GLP-1 analogues: lixisenatide (up to a maximum dose of $20 \mu \mathrm{g}$ QD), liraglutide (1.8 mg QD), semaglutide (0.5 mg or $1.0 \mathrm{mg} \mathrm{QW})$ and extended-release exenatide $(2 \mathrm{mg} \mathrm{QW})$

Bethel et al. [145]. Systematic review To examine the overall CV safety and and meta-analysis of $4 \mathrm{CV}$ outcome trials (EXSCEL, ELIXA, SUSTAIN6, LEADER) efficacy for multiple GLP-1 analogues in adult patients ( $>18$ years) with T2DM
GLP-1 RA treatment group vs. placebo: Significant $10 \%$ RRR in the 3-point major adverse $\mathrm{CV}$ event primary outcome (HR 0.90, 95\% CI $0.82-0.99 ; P=0.33), 13 \% \mathrm{RRR}$ in CV mortality (HR 0.87, 95\% CI 0.79-0.96; $P=0.007), 12 \% \mathrm{RRR}$ in all-cause mortality (HR 0.88, 95\% CI 0.81-0.95; $P=0.002$ ), with low-tomoderate degree of heterogeneity between trials

$C V$ cardiovascular, ELIXA evaluation of lixisenatide in acute coronary syndrome (lixisenatide, maximum dose $20 \mu \mathrm{g}$ per day), EXSCEL exenatide study of cardiovascular event lowering trial (exenatide QW, $2 \mathrm{mg}$ ), LEADER liraglutide effect and action in diabetes: evaluation of cardiovascular outcome results (liraglutide, $1.8 \mathrm{mg} \mathrm{QD}$ ), $M A C E$ major adverse cardiac events, $H R$ hazards ratio, $R R R$ relative risk reduction, $R C T$ s randomised controlled trials, SUSTAIN-6 trial to evaluate cardiovascular and other long-term outcomes with semaglutide in subjects with type 2 diabetes (semaglutide, $0.5 \mathrm{mg}$ or $1.0 \mathrm{mg} \mathrm{qW}), T 2 D M$ type 2 diabetes mellitus 
Table 18 GLP-1 RAs: clinical impact and benefits on renal health

\begin{tabular}{|c|c|}
\hline Study details & Aim \\
\hline \multicolumn{2}{|l|}{ Dulaglutide } \\
\hline $\begin{array}{l}\text { Tuttle et al. [150]. Multicentre, open- } \\
\text { label, randomised interventional } \\
\text { study (AWARD-7) [Dulaglutide } \\
1.5 \mathrm{mg}, n=193 \text { and } 0.75 \mathrm{mg} \text {, } \\
n=190 \text { versus insulin glargine, }\end{array}$ & $\begin{array}{l}\text { To investigate the efficacy and safety of } \\
\text { dulaglutide (1.5 and } 0.75 \mathrm{mg} \text { ) vs. } \\
\text { insulin glargine in T2DM patients } \\
\text { and moderate-to-severe CKD (stage } \\
3-4)\end{array}$ \\
\hline
\end{tabular}

Highlights

$n=194]$. Duration 52 weeks

Tuttle et al. [151]. Pooled analysis of phase II and phase III studies of 9 clinical trials $[N=6005]$. Duration 26 weeks

Exenatide BID

Linnebjerg et al. [152]. Open-label, observational study, 4 parallel study groups $[N=31]$. Duration 30 weeks
To evaluate the PK, safety and tolerability of exenatide BID (5 or $10 \mu \mathrm{g})$ in patients with RI
At 52 weeks, higher eGFR was reported with dulaglutide $1.5 \mathrm{mg}$ (LSM $34.0 \mathrm{~mL} / \mathrm{min} / 1.73 \mathrm{~m}^{2}$ [SE 0.7]; $P=0.005$ vs. insulin glargine), dulaglutide $0.75 \mathrm{mg}$ (LSM $33.8 \mathrm{~mL} /$ $\min / 1.73 \mathrm{~m}^{2}$ [0.7]; $P=0.009$ vs. insulin glargine) (for insulin glargine $31.3 \mathrm{~mL} / \mathrm{min} / 1.73 \mathrm{~m}^{2}$ [0.7]). UACR reduction with dulaglutide $(1.5 \mathrm{mg}$ and $0.75 \mathrm{mg}$ ) was not significantly different from insulin glargine. ESRD occurred in 38 participants: $4 \%$ (dulaglutide $1.5 \mathrm{mg}$ ), $7 \%$ (dulaglutide $0.75 \mathrm{mg}$ ), $8 \%$ (insulin glargine)

To evaluate the effects of dulaglutide on kidney function in patients with T2DM

No significant differences were observed for eGFR between dulaglutide group and comparators. Lower UACR values were observed for dulaglutide vs. placebo, active comparators and insulin glargine (at 26 weeks) and the values were dulaglutide vs. placebo 8.0 [4.4-20.4] vs. $8.0[4.4-23.9] \mathrm{mg} / \mathrm{g}, P=0.023$; dulaglutide vs. active comparators 8.0 [4.4-21.2] vs. 8.9 [4.4-27.4] mg/g, $P=0.013$; and dulaglutide vs. insulin glargine 8.9 [4.4-29.2] vs. $12.4[5.3-50.5] \mathrm{mg} / \mathrm{g}, P=0.029$. Potential acute renal failure (in events/1000 patient-years): 3.4 (dulaglutide), 1.7 (active comparators), 7.0 (placebo). Dulaglutide treatment did not affect eGFR but demonstrated a slight decrease in albuminuria

Well tolerated in mild and moderate RI groups. Therapeutic doses (5 and $10 \mathrm{mg}$ ) are unsuitable in severe RI or ESRD 
Table 18 continued

\begin{tabular}{|c|c|}
\hline Study details & Aim \\
\hline \multicolumn{2}{|l|}{ Exenatide QW } \\
\hline $\begin{array}{l}\text { Loughlin et al. }[153] \text {. Observational, } \\
\text { real-world study; [EQW }(n=2075) \text {, } \\
\text { basal insulin }(n=73,610)] \text {. Duration } \\
3 \text { years }\end{array}$ & $\begin{array}{l}\text { To evaluate the effectiveness and } \\
\text { tolerability of EQW compared with } \\
\text { basal insulin among injectable-drug- } \\
\text { naïve patients with T2DM who are } \\
\text { elderly or have RI }\end{array}$ \\
\hline
\end{tabular}

Highlights

In elderly patients (age $\geq 65$ years),

HbAlc levels changed as follows:

- $0.50 \%$ (EQW), - 0.31\% (BI

initiators). Weight changed as

follows: - $1.6 \mathrm{~kg}$ (EQW initiators),

$0.2 \mathrm{~kg}$ (BI initiators). EQW initiators

had a 1.45 -fold increased risk of

nausea and vomiting compared with

$\mathrm{BI}$ initiators. In RI patients, HbAlc

changed by $-0.58 \%$ (EQW),

$-0.33 \%$ (BI initiators). Weight

changed by $-1.9 \mathrm{~kg}$ (EQW

initiators). No change (BI initiators).

EQW initiators had a 1.28 -fold

increased risk of constipation and

diarrhoea compared with BI

initiators. The renal function,

assessed according to eGFR,

remained stable from baseline for

both EQW and BI initiators,

regardless of RI

Liraglutide

Marso et al. [154]; Leon et al. [155]. To assess the long-term effects of

LEADER $[N=9340]$. Duration

liraglutide on cardiovascular

3.8 years

outcomes and other clinically

important events

In liraglutide-treated arm: $26 \%$ reduced macroalbuminuria

(HR $0.74[0.60-0.91]) .19 \%$ reduced urine ACR (CI 0.14\%-0.24\%).

Gained significantly greater $\mathrm{CV}$

benefit who had an eGFR $<60 \mathrm{~mL} /$

$\mathrm{min} / 1.73 \mathrm{~m}^{2}$ (HR 0.69 [0.57-0.85])

than those with an eGFR $>60 \mathrm{~mL} /$

$\min / 1.73 \mathrm{~m}^{2}$ (HR 0.94 [0.83-1.07]).

Doubling of serum creatinine

concentration to an eGFR $\leq 45 \mathrm{~mL} /$

$\min / 1.73 \mathrm{~m}^{2}$ was unaffected. ESRD

or renal death incidence was small 
Table 18 continued

\begin{tabular}{l}
\hline Study details \\
Davies et al. [156]. Randomised, \\
double-blind, placebo-controlled, \\
parallel-group trial; LIRA-renal study \\
[liraglutide $(n=140)$ or placebo \\
$(n=139)]$. Duration 26 weeks \\
Idorn et al. [157]. Investigator- \\
initiated, placebo-controlled, double- \\
blind, parallel-group, randomised \\
trial [patients with T2DM and \\
ESRD $(n=24)$ and control subjects \\
with T2DM and normal kidney \\
function $(n=23)]$. Duration \\
12 weeks
\end{tabular}

Aim

To examine the efficacy and safety of liraglutide in patients with T2DM and moderate renal impairment

To evaluate the parameters related to the safety and efficacy of liraglutide in patients with T2DM and dialysisdependent ESRD

\section{Highlights}

No changes in renal function (eGFR relative ratio to baseline $-1 \%$ [liraglutide], + 1\% [placebo]; estimated treatment ratio [ETR] $0.98, P=0.36)$. The most common AEs were of GI in nature: $35.7 \%$ (liraglutide), $17.5 \%$ (placebo), with no difference in hypoglycaemic episodes

Liraglutide vs. control group: $49 \%$ increase in dose-corrected plasma trough concentration in ESRD group (95\% CI 6-109, $P=0.02$ ). Nausea and vomiting (initial and temporary) occurred more frequently in patients with ESRD $(P<0.04)$. In both liraglutide-treated groups significant improvement in glycaemic control $(P<0.01)$ and reduction in the dose of baseline insulin $(P<0.04)$. Body weight reduction was observed in $-2.4 \pm 0.8 \mathrm{~kg}, P=0.22$ (ESRD group) and $2.9 \pm 1.0 \mathrm{~kg}, P=0.03$ (control group)

Lixisenatide

Pfeffer et al. [133]. CVOT, ELIXA. Duration 25 months
To assess the effects of lixisenatide in patients with T2DM who had had a recent acute coronary event
Median UACR increased to $24 \%$ (CI 19-30\%) compared to placebo with an increase of 34\% (CI 24-40\%) 
Table 18 continued

\begin{tabular}{l} 
Study details \\
\hline Tonneijck et al. [158]. Phase 4, single- \\
centre, randomised, open-label, \\
comparator-controlled, parallel-group \\
intervention trial $[N=35]$. \\
Duration 8 weeks
\end{tabular}

Hanefeld et al. [159]. Post hoc assessment of 9 lixisenatide trials in the GetGoal clinical trial programme [normal renal function (lixisenatide $n=2094$, placebo $n=1150$ ); renal impairment (mild: lixisenatide $n=637$, placebo $n=414$; moderate: lixisenatide $n=122$, placebo $n=68)]$. Duration 12-24 weeks

Semaglutide

Marso et al. [160]. CVOT, SUSTAIN-6 [ $N=3297]$. Duration 154 weeks
Aim

To evaluate whether lixisenatide when added to insulin glargine ameliorates postprandial glomerular hyperfiltration in overweight patients with T2DM compared with insulin glulisine

To assess the efficacy and safety of once-daily lixisenatide in patients with T2DM with normal-tomoderate renal impairment

To assess the non-inferiority of semaglutide as compared with placebo in terms of cardiovascular safety in patients with T2DM

\section{Highlights}

No effect on eGFR $(+0.1 \mathrm{~mL} / \mathrm{min} /$ $1.73 \mathrm{~m}^{2}$ ) [95\% CI - 9 to 9] and ERPF $\left(-17 \mathrm{~mL} / \mathrm{min} / 1.73 \mathrm{~m}^{2}\right.$ [-61 to 26$]$ ), other (intra-)renal haemodynamics or renal damage markers as compared to insulin glulisine. Increased fractional sodium excretion $[+0.25 \%(0.09-0.41)]$ and urinary $\mathrm{pH}[+0.7(0.3-1.2)]$.

Unchanged: Plasma renin, angiotensin II and aldosterone levels. Decreased HbA1c level in both groups. PPBG was lower. Prolonged treatment resulted in sustained natriuretic effect in contrast to reports on long-acting GLP-1 RAs

Reduced HbA1c, PPBG and FBG in lixisenatide-treated patients vs. placebo. Mild renal impairment vs. normal kidney function: $14 \%$ higher incidence of GI, 10\% higher incidence of nausea and vomiting $(P=0.003$ for both $)$

Treatment reduced the frequency of new or worsening nephropathy (HR 0.64 [0.46-0.88], $P=0.005)$.

Doubling of serum creatinine concentration to an $\mathrm{eGFR} \leq 45 \mathrm{~mL} / \mathrm{min} / 1.73 \mathrm{~m}^{2}$, ESRD or renal death were unaffected; however, the event rate was too low $(<1 \%)$ to sufficiently explore these outcomes 
Table 18 continued

\begin{tabular}{|c|c|c|}
\hline Study details & Aim & Highlights \\
\hline $\begin{array}{l}\text { Marbury et al. [161]. Multicentre, } \\
\text { single-dose, open-label, parallel-group } \\
\text { study }[N=54] \text {. Duration } 21 \text { days }\end{array}$ & $\begin{array}{l}\text { To compare the } \mathrm{PK} \text { and tolerability of } \\
\text { semaglutide }(0.5 \mathrm{mg}) \text { in T2DM } \\
\text { patients with mild/moderate RI or } \\
\text { ESRD versus those with normal renal } \\
\text { function }\end{array}$ & $\begin{array}{l}\text { Mean semaglutide exposure was } 22 \% \\
\text { higher than subjects with normal } \\
\text { renal function. No relationship } \\
\text { between } \mathrm{CL}_{\mathrm{CR}} \text { and semaglutide } \\
\text { exposure, or between } \mathrm{CL}_{\mathrm{CR}} \text { and } \\
\text { semaglutide } \mathrm{C}_{\text {max }} \text {. Haemodialysis did } \\
\text { not affect the } \mathrm{PK} \text { of semaglutide }\end{array}$ \\
\hline
\end{tabular}

$\overline{A C R}$ albumin-to-creatinine ratio, $A E s$ adverse events, $A W A R D$ assessment of weekly administration of LY2189265 in diabetes (dulaglutide, $0.75 \mathrm{mg}$ or $1.5 \mathrm{mg}$ qw), bi basal insulin, $C_{\max }$ maximum plasma drug concentration, $C K D$ chronic kidney disease, $C L_{C R}$ creatinine clearance, CVOT cardiovascular outcome trials, ELIXA evaluation of lixisenatide in acute coronary syndrome (lixisenatide, maximum dose $20 \mu \mathrm{g}$ per day), eGFR estimated glomerular filtration rate, $E R P F$ effective renal plasma flow, ESRD end-stage renal disease, EQW exenatide QW, FBG fasting blood glucose, GLP-1 RA glucagon-like peptide-1 receptor agonist, GI gastrointestinal, $L S M$ least squares mean, $P K$ pharmacokinetics, $P P B G$ postprandial blood glucose, $R I$ renal impairment, $S E$ standard error, $S U S T A I N-6$ trial to evaluate cardiovascular and other long-term outcomes with semaglutide in subjects with type 2 diabetes (semaglutide, $0.5 \mathrm{mg}$ or $1.0 \mathrm{mg} \mathrm{QW}$ ), T2DM type 2 diabetes mellitus, $U A C R$, urine albumin-to-creatinine ratio

hepatic impairment. Prescribing information of the respective products advises cautious use in this patient population; however, there is no dosage adjustment recommended [192, 193]. The impact of GLP-1 RAs on hepatic health is presented in the clinical impact section.

\section{GLP-1 RAs Use in Special Situations}

\section{Elderly}

Characteristics that inform the choice of effective antidiabetic medications in the elderly include medications with relatively low risk of hypoglycaemia and glycaemic variability without overt GI side effects to prevent malnutrition and worsening frailty. It is important to reduce regimen complexity and avoid episodes of hypo- and hyperglycaemia. This should be specifically considered in patients with cognitive problems. Ageing is described as a progressive impairment in carbohydrate tolerance which may be related to disorderly insulin release, reduced insulin production, reduced GLP-1 secretion, increased adiposity, sarcopenia and physical inactivity. GLP-1 RAs are known to have low risk of hypoglycaemia and offer least glycaemic variability [194].
The key clinical evidence in elderly population for various GLP-1 RAs is presented in Table 23.

\section{Paediatric and Adolescents}

The uses of GLP-1 RAs are widely used in adults for glycaemic control and other benefits associated with the drug. Table 24 presented the key clinical evidence in paediatric and adolescent population.

\section{Sleep Apnoea}

The key clinical evidence on sleep apnoea for various GLP-1 RAs is presented in Table 25.

\section{Fasting Conditions: Ramadan}

GLP-1 RAs do not cause hypoglycaemia; hence, dose adjustments or modification is not required during fasting days. The dose of GLP-1 analogues, liraglutide, exenatide or lixisenatide, should be the same as pre-Ramadan dose even when used with insulin. However, dose adjustments are required for insulin, sulfonylureas or any other antidiabetics which can cause hypoglycaemia when administered concomitantly with GLP-1 RAs. Other oral hypoglycaemic agents do not require dose adjustments. 
Table 19 GLP-1 RAs: clinical impact and benefits on hepatic health

\begin{tabular}{lc}
\hline Study details & Aim \\
\hline Dulaglutide & \\
Seko et al. [171]. Retrospective study & To evaluate the efficacy and safety of \\
{$[N=15]$. Duration 12 weeks } & dulaglutide $(0.75 \mathrm{mg})$ in Japanese \\
& NAFLD patients with T2DM
\end{tabular}

Highlights

\section{Dulaglutide}

Seko et al. [171]. Retrospective study $[N=15]$. Duration 12 weeks

Exenatide BID

Klonoff et al. [101]. Open-ended, open-label clinical trial $[N=217$ subjects; $n=116$, baseline].

Duration 3 years

Shao et al. [172]. Prospective RCT $[N=60]$. Duration 12 weeks

Exenatide QW

Bergenstal et al. [173]. Analysis $[N=675]$. Duration 52 weeks
To evaluate the effects of exenatide BID on glycaemic control, body weight, cardiometabolic markers and safety

To evaluate the advantages of exenatide treatment on obesity and NAFLD with elevated liver enzymes in T2DM patients

To evaluate the potential effects of exenatide once weekly on glycaemic control and $\mathrm{CV}$ risk factors
Significant decrease in transaminase activities: AST - 8.9 IU/L [baseline $=50.4 \pm 6$ ], $P=0.03$; ALT - $11 \mathrm{IU} / \mathrm{L}$

[baseline $=52.1 \pm 7.2$ ] $P=0.003$ was observed. Reduction in total body fat mass and liver stiffness was observed

ALT reduction $(-10.4 \pm 1.5 \mathrm{IU} / \mathrm{L}$; $P<0.0001)$ was observed; normal ALT levels were achieved in $41 \%$ of the treated patients

Exenatide vs. intensive insulin group: Significantly lower levels of ALT, AST and $\gamma$ GGT and correlated mean body weight change $(P<0.001)$. Significantly $(P<0.01)$ higher fatty liver reversal rate: $93.3 \%$ (exenatide), $66.7 \%$ (intensive insulin)

Significant ALT reduction: - 4.3 (0.71) IU/L, with greater improvements in patients with elevated ALT levels at baseline

Resolution of definite NASH: 9 (39\%) in liraglutide group, 2 (9\%) in placebo (RR 4.3 [95\% CI 1.0-17.7]; $P=0.019)$. Fibrosis progression: 2 (9\%) of 23 patients in liraglutide group, 8 (36\%) of 22 patients in the placebo group (RR 0.2 [95\% CI 0.1-1.0]; $P=0.04)$. Liraglutide administration led to histological resolution of non-alcoholic steatohepatitis 
Table 19 continued

\begin{tabular}{ll}
\hline Study details & Aim \\
\hline Lixisenatide & \\
Gluud et al. [175]. Systematic review & To evaluate the effects of lixisenatide \\
$\begin{array}{ll}\text { and meta-analysis of 15 RCTs. } & \text { on elevated liver transaminase levels } \\
\text { Duration 4-76 weeks } & \text { in patients with T2DM }\end{array}$
\end{tabular}

Multiple GLP-1 RAs

Carbone et al. [176]. Systematic review and meta-analysis (randomeffects model) of 4 studies $[N=136]$. Duration 16-56 weeks

Cuthbertson et al. [177]. Prospective study $[N=25]$. Duration 6 months

\author{
To evaluate the efficacy of incretin- \\ based therapies (GLP-1 RA and \\ DPP4i) in treating NAFLD via a \\ structured retrieval and pooled \\ analysis of relevant studies
}

To determine the impact of GLP-1 RA therapy on IHL levels in obese T2DM patients with hepatic steatosis, and evaluate the interrelationship between changes in IHL with those in $\mathrm{HbAlc}$, body weight, and volume of abdominal VAT and SAT

\section{Highlights}

At 29 weeks, beneficial effect on normalisation of ALT among obese patients $(P=0.01)$ or overweight $(P=0.004)$, but not among normal weight patients $(P=0.98)$ was observed

Post incretin-based therapies: Significant ALT reduction (MR 14.1 IU/L; 95\% CI 8.3-19.8, $P<0.0001)$. Significant reduction $(P<0.05)$ in steatosis, inflammation and fibrosis in imaging and tissue data was demonstrated in 2 studies

Treatment group associated with mean weight loss of $5.0 \mathrm{~kg}$ (95\% CI 3.5-6.5), mean HbAlc reduction of $1.6 \%$ (95\% CI $0.8-2.4$ ), $42 \%$ relative reduction in IHL $(95 \% \mathrm{CI}$ 16.5-59.3). In individuals with highest pre-treatment levels, a greater IHL reduction was observed

ALT alanine aminotransferase, $A S T$ aspartate aminotransferase, $C V$ cardiovascular, $D P P-4$ i dipeptidyl peptidase- 4 inhibitor, GLP-1 RA glucagon-like peptide-1 receptor agonist, GGT gamma-glutamyl transferase, HbA1c glycated haemoglobin, $I H L$ intrahepatic lipid, $L E A N$ liraglutide safety and efficacy in patients with non-alcoholic steatohepatitis, $N A F L D$ non-alcoholic fatty liver disease, $N A S H$ non-alcoholic steatohepatitis, $R C T$ randomised controlled trial, $R R$ relative risk, $S A T$ subcutaneous adipose tissue, $T 2 D M$ type 2 diabetes mellitus, $V A T$ visceral adipose tissue

Table 26 presents the guidelines for the use of GLP-1 RAs during Ramadan.

\section{Polycystic Ovary Syndrome}

PCOS is one of the most common endocrine disorders that affect women of reproductive age [206]. PCOS is associated with high levels of androgen and insulin (hyperinsulinaemia) which contribute to the risk of developing disorders including obesity, high $\mathrm{BP}$, high cholesterol, diabetes mellitus and CVD [207, 208]. Excess body weight is a key phenotype of PCOS wherein $60-70 \%$ of women with this condition are reported to be obese or overweight [206]. Another common feature associated with PCOS is insulin resistance [209].

Women with PCOS are 5-10 times more prone to the risk of developing T2DM, and the progression from impaired glucose tolerance to T2DM is faster in women with PCOS compared to women without PCOS (age and weight matched) [210].

Reduction in body weight has been demonstrated to improve hyperandrogenism, reproductive function and metabolic parameters such as hypertension, hyperlipidaemia and 
Table 20 GLP-1 RAs: clinical impact and benefits in pancreatitis

Study details
Storgaard et al. [179]. Systematic review
and meta-analysis of 3 multicentre,
double-blinded, placebo-controlled
RCTs (ELIXA, LEADER,
SUSTAIN-6) [GLP-1 RA treated,
$n=9347 ;$ placebo treated, $n=9353$ ].
Duration 24 months
Dulaglutide
Nauck et al. [180]. Integrated
assessment of 9 trials, 4 phase 2 trials
(trials $1-4)$ and 5 phase 3
confirmatory trials (AWARD $1-5)$
[dulaglutide ( $n=4006$ ), placebo
$(n=703)$, insulin glargine
$(n=1541)$ ]. Duration 104 weeks

Aim

To assess the risk of AP (predefined

$\mathrm{AE})$ in patients with T2DM with

GLP-1 RA
Highlights

GLP-1 RA was not associated with increased risk of AP (OR 0.745 [95\% CI 0.47-1.17]).
To evaluate the risk of AP during treatment with dulaglutide, placebo and active comparators ${ }^{\mathrm{a}}$

\begin{abstract}
AP was confirmed in 7 patients distributed in all groups. Exposureadjusted incidence rates (in patients/ 1000 patient-years) were as follows: dulaglutide group 0.85 , placebo group 3.52 and sitagliptin group 4.71
\end{abstract}

Liraglutide

Jensen et al. [181]. Post hoc review of pooled and patient-level data of phase 2 and 3 RCTs $[N=9016]$. Duration 1 year

Steinberg et al. [182]. Secondary analyses of pooled data of the phase 3a, 4 randomised, placebo-controlled trials from the SCALE clinical development programme $[N=5358]$. Duration 32 weeks-3 years
To report the incidence of $\mathrm{AP}$ and CP in T2DM trials of liraglutide vs. active comparator groups ${ }^{b}$ vs. placebo

To investigate the association between amylase/lipase activity levels and subsequent AP occurrence
AP cases: 8 (liraglutide) and 1 (comparator group, glimepiride). AP and $\mathrm{CP}$ incidence reports were greater with liraglutide than comparators

Liraglutide resulted in dose-independent, reversible increase in amylase/lipase activity. Gallstones possibly contributed to $50 \%$ of AP cases

$A E$ adverse event, $A P$ acute pancreatitis, AWARD assessment of weekly administration of LY2189265 in diabetes (dulaglutide, $0.75 \mathrm{mg}$ or $1.5 \mathrm{mg} \mathrm{QW}), C P$ chronic pancreatitis, ELIXA evaluation of lixisenatide in acute coronary syndrome (lixisenatide, maximum dose $20 \mu \mathrm{g}$ per day), GLP-1 RA glucagon-like peptide-1 receptor agonist, $L E A D E R$ liraglutide effect and action in diabetes: evaluation of cardiovascular outcome results (liraglutide, $1.8 \mathrm{mg} \mathrm{QD}$ ), $O R$ odds ratio, $R C T s$ randomised controlled trial, SCALE satiety and clinical adiposity-liraglutide evidence in individuals with and without diabetes, SUSTAIN-6 trial to evaluate cardiovascular and other long-term outcomes with semaglutide in subjects with type 2 diabetes (semaglutide, $0.5 \mathrm{mg}$ or $1.0 \mathrm{mg} \mathrm{QW}$ ), T2DM type 2 diabetes mellitus

a Including metformin, sitagliptin, exenatide BID and insulin glargine

b Glimepiride, rosiglitazone, insulin glargine, sitagliptin and exenatide

glycaemic control in women with PCOS [211, 212].

GLP-1 RAs have expanded the treatment option for PCOS owing to their ability to influence both body weight and glycaemic control. These agents are also associated with a modest decrease in BP and improvement in hyperlipidaemia [206]. The evidence on the use of GLP-1 RAs for the treatment of PCOS in women is currently available only for exenatide BID and liraglutide QD. 
Table 21 GLP-1 RAs: clinical impact and benefits in cholelithiasis

\begin{tabular}{|c|c|c|c|}
\hline $\begin{array}{l}\text { GLP-1 RAs } \\
\text { included in the } \\
\text { study }\end{array}$ & Study details & Aim & Highlights \\
\hline $\begin{array}{l}\text { Exenatide, liraglutide, } \\
\text { lixisenatide, } \\
\text { albiglutide, } \\
\text { dulaglutide and } \\
\text { semaglutide [183] }\end{array}$ & $\begin{array}{l}\text { Systematic review and meta- } \\
\text { analysis of randomised } \\
\text { controlled trials [GLP-1 RA } \\
(n=33,167), \text { comparator } \\
\text { arms }(n=26,683)] . \\
\text { Duration } 41.7 \text { weeks }\end{array}$ & $\begin{array}{l}\text { To evaluate the effect of GLP-1 } \\
\text { RA treatment on the } \\
\text { incidence of pancreatitis, } \\
\text { pancreatic cancer and } \\
\text { cholelithiasis in patients with } \\
\text { T2DM }\end{array}$ & $\begin{array}{l}\text { Significant increase in } \\
\text { cholelithiasis with GLP-1 RAs } \\
\text { (OR } 1.30 \text { [95\% CI } \\
1.01-1.68], P=0.041) \text {. No } \\
\text { significant difference in } \\
\text { incidence of pancreatitis and } \\
\text { pancreatic cancer in both the } \\
\text { arms }\end{array}$ \\
\hline
\end{tabular}

GLP-1 RA glucagon-like peptide-1 receptor agonist, $O R$ odds ratio, T2DM type 2 diabetes mellitus

Table 22 Data on GLP-1 RA use in patients with CKD (based on European Union label)

\begin{tabular}{|c|c|c|c|c|c|c|}
\hline \multicolumn{2}{|c|}{ Drug class and dosing } & \multicolumn{5}{|c|}{ eGFR $\left(\mathrm{mL} / \mathrm{min} / 1.73 \mathrm{~m}^{2}\right)$ (associated stage) } \\
\hline$\overline{\text { GLP-1 RAs }}$ & Licensed dose & $\begin{array}{l}60-89 \\
\text { (stage 2) }\end{array}$ & $\begin{array}{l}45-59 \\
\text { (stage 3a) }\end{array}$ & $\begin{array}{l}30-44 \text { (stage } \\
3 b)\end{array}$ & $\begin{array}{l}15-29 \\
\text { (stage 4) }\end{array}$ & $\begin{array}{l}<15 \\
\text { (stage 5) }\end{array}$ \\
\hline $\begin{array}{l}\text { Dulaglutide QW } \\
\text { [186] }\end{array}$ & $\begin{array}{l}0.75-1.5 \mathrm{mg} \text { SC injection } \\
\text { QW }\end{array}$ & $\checkmark$ & $\checkmark$ & $\checkmark$ & $x$ & $x$ \\
\hline $\begin{array}{l}\text { Exenatide BID } \\
{[187]}\end{array}$ & 5-10 $\mu \mathrm{g}$ SC injection BID & $\checkmark$ & $\boldsymbol{V}^{a}$ & - & $x$ & $x$ \\
\hline $\begin{array}{l}\text { Exenatide QW } \\
\quad[188]\end{array}$ & $2 \mathrm{mg}$ SC injection $\mathrm{QW}$ & $\checkmark$ & $\boldsymbol{V}^{a}$ & $x$ & $x$ & $x$ \\
\hline $\begin{array}{l}\text { Liraglutide QD } \\
\quad[189]\end{array}$ & $0.6-1.8 \mathrm{mg} \mathrm{SC}$ injection QD & $\checkmark$ & $\checkmark$ & $\checkmark$ & $x$ & $x$ \\
\hline $\begin{array}{l}\text { Lixisenatide QD } \\
\text { [190] }\end{array}$ & 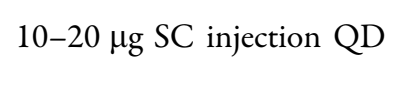 & $\checkmark$ & $\boldsymbol{V}^{\mathrm{a}, \mathrm{b}}$ & - & $x$ & $x$ \\
\hline $\begin{array}{l}\text { Semaglutide QW } \\
\text { [191] }\end{array}$ & $\begin{array}{l}0.25,0.5 \text { and } 1 \mathrm{mg}, \mathrm{SC} \\
\text { injection } \mathrm{QW}\end{array}$ & $\checkmark$ & $\boldsymbol{\nu}^{\mathrm{a}}$ & $\boldsymbol{V}^{a}$ & $\boldsymbol{V}^{\mathrm{a}}$ & $x$ \\
\hline
\end{tabular}

$C K D$ chronic kidney disease, $e G F R$ estimated glomerular filtration rate, GLP-1 RA glucagon-like peptide-1 receptor agonist, $S C$ subcutaneous, $\boldsymbol{V}$ indicated and no dose adjustment required, - indication may be variable/consider dose reduction, frequent monitoring and relevant health status, $\boldsymbol{X}$ contraindicated

a No dose adjustment required if eGFR is $>50 \mathrm{~mL} / \mathrm{min}$

b Contraindicated if eGFR $<50 \mathrm{~mL} / \mathrm{min}$

\section{Pregnancy and Lactation}

Animal studies have reported reproductive toxicity with all GLP-1 RAs and hence use of GLP-1 RAs is contraindicated during pregnancy. It is not recommended for use in breastfeeding women. Women of childbearing age are advised to use contraception during treatment [213]. GLP-1 RA use in special population according to the prescribing information/package insert is summarised in Table 27. 
Table 23 GLP-1 RAs in a special population: the elderly

\begin{tabular}{|c|c|c|}
\hline Study details & Aim & Highlights \\
\hline \multicolumn{3}{|l|}{ Dulaglutide $(1.5$ and $0.75 \mathrm{mg}$ ) } \\
\hline $\begin{array}{l}\text { Boustani et al. }[195] \text {. Pooled analysis } \\
\text { from } 6 \text { phase } 3 \text { clinical studies } \\
{[\geq 65 \text { years, } n=958 ;<65 \text { years, }} \\
n=4213] . \text { Duration } 26 \text { weeks }\end{array}$ & $\begin{array}{l}\text { To evaluate the efficacy and safety of } \\
\text { dulaglutide in elderly patients with } \\
\text { T2DM }\end{array}$ & $\begin{array}{l}\text { Lower hypoglycaemia incidence if } \\
\text { patients were not on concomitant } \\
\text { SU or insulin therapy. Similar GI } \\
\text { AEs incidence with both doses }\end{array}$ \\
\hline
\end{tabular}

Exenatide BID $(10 \mu \mathrm{g})$

Pencek et al. [196]. Post hoc analysis from 16 RCTs $(\geq 65$ years,

$n=454 ;<65$ years, $n=1613)$.

To assess the efficacy and safety of exenatide BID in patients with T2DM

Duration $12-30$ weeks

\section{Exenatide QW (2 mg)}

Loughlin et al. [153]. Observational, real-world study [EQW $(n=2075)$, BI $(n=73,610)]$. Duration 3 years

To evaluate the effectiveness and tolerability of EQW compared with $\mathrm{BI}$ among injectable-drug-naïve patients with T2DM who are elderly (age $\geq 65$ years) or have RI

Improvements in $\mathrm{HbAlc}, \mathrm{FBG}$ and lipid levels (except HDL-C) in both age groups. $\geq 65$ years age group: Lower hypoglycaemia incidence (1.2\%) if not on concomitant SU and fewer fall-related injuries

In elderly patients, $\mathrm{HbAlc}$ levels changed by $-0.50 \%$ (EQW initiators), and $-0.31 \%$ (BI initiators) from baseline to follow-up. Weight changed by $-1.6 \mathrm{~kg}$ (EQW initiators) and $0.2 \mathrm{~kg}$ (BI initiators). Stable renal function from baseline for both initiator groups. 1.45-fold increased risk of nausea and vomiting with $\mathrm{EQW}$ initiators than $\mathrm{BI}$ initiators

Pencek et al. [197]. Post hoc analysis

To evaluate the efficacy and tolerability of pooled data from 7 randomised, of EQW in patients with T2DM

Significant improvements in HbAlc, FBG and body weight, BP, lipids. Most common AEs: GI in nature controlled, phase 3 trials $[n=1719)$ including age $(<65$ or $\geq 65$ years).

Duration 24-30 weeks

Liraglutide (up to $1.8 \mathrm{mg} /$ day)

Gilbert et al. [198]. Post hoc analysis

To assess the risk of $\mathrm{CV}$ events and allof randomised, placebo-controlled, double-blind, $\mathrm{CV}$ outcomes cause mortality in elderly patients with T2DM

Significant reduction in CV risk events and all-cause mortality $(P<0.05)$ as compared to placebo

LEADER trial $[N=9340]$.

Duration 3.5-5 years

Chitnis et al. [199]. Real-world retrospective cohort study $[\geq 65$ years $(n=517)]$. Duration 6-12 months

To assess the clinical effectiveness of liraglutide in patients with T2DM
Significant and sustained reduction in HbAlc and weight $(P<0.01)$. No evidence of severe hypoglycaemia 
Table 23 continued

\begin{tabular}{|c|c|c|}
\hline Study details & Aim & Highlights \\
\hline \multicolumn{3}{|l|}{ Lixisenatide $(20 \mu \mathrm{g})$} \\
\hline $\begin{array}{l}\text { Raccah et al. [200]. Pooled data from } \\
6 \text { placebo-controlled phase } 3 \text { trials } \\
\text { from lixisenatide [elderly } \\
(\geq 65 \text { years, } n=544) \text { and very } \\
\text { elderly }(\geq 75 \text { years, } n=79)] \\
\text { Duration } 12-24 \text { months }\end{array}$ & $\begin{array}{l}\text { To evaluate the efficacy and safety of } \\
\text { lixisenatide QD in elderly and very } \\
\text { elderly patients }\end{array}$ & $\begin{array}{l}\text { Placebo-adjusted HbAlc reductions } \\
\text { were comparable with the younger } \\
\text { age groups }(<65 \text { and }<75 \text { years } \\
\text { old). Maintained efficacy in patients } \\
\text { with more severe } \beta \text {-cell dysfunction. } \\
\text { Reported symptomatic } \\
\text { hypoglycaemia in patients with } \\
\text { insulin as concomitant medication }\end{array}$ \\
\hline \multicolumn{3}{|l|}{ Semaglutide $(0.5$ or $1.0 \mathrm{mg})$} \\
\hline $\begin{array}{l}\text { Warren et al. [201]. Pooled analysis of } \\
\text { phase } 3 \text { SUSTAIN } 1-5 \text { trials (elderly } \\
\geq 65 \text { years, } n=854 ; \text { non-elderly } \\
<65 \text { years, } n=3045 \text { ). Duration } \\
30-56 \text { weeks }\end{array}$ & $\begin{array}{l}\text { To assess the efficacy and safety of } \\
\text { semaglutide vs. comparators in } \\
\text { patients with T2DM }\end{array}$ & $\begin{array}{l}\text { Consistent improvement in HbAlc } \\
\text { and body weight across both age } \\
\text { groups. }>85 \% \text { of treated elderly } \\
\text { patients achieved a less stringent } \\
\text { target of HbAlc }<8 \% \text {. Premature } \\
\text { treatment discontinuations were } \\
\text { higher in elderly versus non-elderly } \\
\text { patients. No increased risk of } \\
\text { hypoglycaemia was observed }\end{array}$ \\
\hline
\end{tabular}

AEs adverse events, $B I$ basal insulin, EQW exenatide QW, $C V$ cardiovascular, $F B G$ fasting blood glucose, $G I$ gastrointestinal, GLP-1 RA glucagon-like peptide-1 receptor agonist, $H b A 1 c$ glycated haemoglobin, $H D L-C$ high-density lipoprotein cholesterol, $L E A D E R$ liraglutide effect and action in diabetes: evaluation of cardiovascular outcome results (liraglutide, $1.8 \mathrm{mg} \mathrm{QD}), R C T$ s randomised controlled trial, $R I$ renal impairment, $S U$ sulfonylurea, SUSTAIN-6 trial to evaluate cardiovascular and other long-term outcomes with semaglutide in subjects with type 2 diabetes (semaglutide, 0.5 mg or $1.0 \mathrm{mg} \mathrm{QW}), T 2 D M$ type 2 diabetes mellitus

\section{Checklists for GLP-1 RA Therapy Initiation}

GLP-1 RA therapy initiation is largely influenced by clinical requisites of patients. The criteria for patient selection for GLP-1 RA-based therapy, ideal patient type, rationale for initiation of different kinds of GLP-1 RA-based therapy and factors affecting the selection of the appropriate GLP-1 RA are discussed below.

\section{Patient Selection and Rationale for GLP-1 RA-Based Therapy Initiation}

Checklists for patient selection and rationale for GLP-1 RA-based therapy initiation are listed in Fig. 4.

\section{Factors Influencing the Selection of Appropriate GLP-1 Analogue}

An array of GLP-1 analogues are available on the market, and a few others are at various stages of approval to be released in the near future. Given the range and unique pharmacological properties, a patient-centred approach is feasible with this class of drugs. The factors that influence the choice of GLP-1 RA could be largely classified into biomedical and psychosocial factors [214].

\section{Biomedical Factors}

Biomedical factors that dictate the choice of GLP-1 RAs consist of efficacy, safety and tolerability along with its versatility in combination with insulin [214]. The efficacy of GLP-1 RAs 
Table 24 GLP-1 RAs in special populations: paediatric and adolescents

\begin{tabular}{|c|c|c|}
\hline Study details & Aim & Highlights \\
\hline \multicolumn{3}{|l|}{ Exenatide } \\
\hline $\begin{array}{l}\text { Censani et al. [202]. Case series } \\
{[N=2] \text {. Duration } 3-6 \text { months }}\end{array}$ & $\begin{array}{l}\text { To report the effects of exenatide on } \\
\text { metabolic risk and weight in } \\
\text { adolescents with morbid obesity and } \\
\text { T2DM }\end{array}$ & $\begin{array}{l}\text { Exenatide treatment resulted in } \\
\text { improvements in cardiometabolic risk } \\
\text { factors }^{\mathrm{a}}\end{array}$ \\
\hline \multicolumn{3}{|l|}{ Liraglutide } \\
\hline $\begin{array}{l}\text { Klein et al. [203]. Randomised, } \\
\text { double-blind, placebo-controlled } \\
\text { trial }[N=21] . \text { Duration } \\
5 \text { weeks }\end{array}$ & $\begin{array}{l}\text { To assess the safety, tolerability, PK/PD } \\
\text { of liraglutide (monotherapy or } \\
\text { combination therapy with metformin) } \\
\text { in youth (10-17 years old) with T2DM }\end{array}$ & $\begin{array}{l}\text { Liraglutide } 1.8 \mathrm{mg}: t_{1 / 2}=12 \mathrm{~h}, \\
\text { clearance }=1.7 \mathrm{~L} / \mathrm{h} \text {. Liraglutide } 1.8 \mathrm{mg} \\
\text { resulted in greater decline in HbAlc } \\
\text { level compared with placebo (- } 0.86 \text { vs. } \\
0.04 \%, P=0.0007) \text {, no severe } \\
\text { hypoglycaemia but transient GI AEs } \\
\text { during dose escalation. Liraglutide } \\
1.8 \mathrm{mg} \text { was safe and well tolerated }\end{array}$ \\
\hline $\begin{array}{l}\text { Zhou et al. [204]. Prospective } \\
\text { randomised controlled trial } \\
{[N=42] . \text { Duration } 3 \text { months }}\end{array}$ & $\begin{array}{l}\text { To evaluate the clinical efficacy of GLP-1 } \\
\text { RAs for reversal of normal blood } \\
\text { glucose in children with pre-diabetes }\end{array}$ & $\begin{array}{l}\text { GLP-1 analogues were better as compared } \\
\text { to control group owing to significantly } \\
\text { lower FBG and } 2 \mathrm{~h} \text { PPBG levels (post } \\
1 \text { month) }(P<0.01) \text {; statistically better } \\
\text { controlled HbAlc, lipids and BMI (post } \\
3 \text { months); significantly decreased IR } \\
\text { index }(P<0.05) \text {; statistically higher } \\
\text { values of the } \beta \text {-cell islet function index } \\
(P<0.05)\end{array}$ \\
\hline
\end{tabular}

$A E s$ adverse events, $B P$ blood pressure, $B M I$ body mass index, $F B G$ fasting blood glucose, $G I$ gastrointestinal, $G L P-1 R A$ glucagon-like peptide-1 receptor agonist, $H b A 1 c$ glycated haemoglobin, $I R$ insulin resistance, $P D$ pharmacodynamics, $P K$ pharmacokinetics, $P P B G$ postprandial blood glucose, T2DM type 2 diabetes mellitus

a Triglyceride levels, BP, FBG, HbAlc

largely depends on their ability to exert a stronger effect on either fasting or postprandial glucose. Long-acting agents are known to act on fasting blood glucose to a larger extent, whereas short-acting agents are known to have a greater effect on PPBG. Therefore, the choice of the drug could depend on the time when the patient is experiencing glucose fluctuations. Interestingly, GLP-1 RAs such as dulaglutide, liraglutide and lixisenatide are reported to have exhibited clinically relevant fasting and postprandial glycaemic benefits [22, 214, 215].

The duration of action also determines the possible combination with insulin (short-acting insulin or basal) owing to their complementary pharmacology; theoretically, this combination influences both fasting and postprandial glucose [214].

The choice of GLP-1 RAs may also be influenced by the anticipated AEs including upper and/or lower GI AEs which may vary among GLP-1 analogues and autonomic functions such as GI motility [39, 178, 214, 216].

Other factors to be considered are the effect of GLP-1 RAs on cardiac and renal systems and other comorbidities of concern [214]. 
Table 25 GLP-1 RAs in a special population: sleep apnoea

\begin{tabular}{|c|c|c|}
\hline Study details & Aim & Highlights \\
\hline \multicolumn{3}{|l|}{ Liraglutide } \\
\hline $\begin{array}{l}\text { Blackman et al. [205]. SCALE Sleep Apnoea } \\
\text { randomised, double-blind, placebo- } \\
\text { controlled parallel-group trial [liraglutide, } \\
n=180 \text {; placebo, } n=179] \text {. Duration } \\
32 \text { weeks }\end{array}$ & $\begin{array}{l}\text { To investigate whether } \\
\text { liraglutide } 3.0 \mathrm{mg} \text { reduces } \\
\text { OSA severity versus } \\
\text { placebo }\end{array}$ & $\begin{array}{l}\text { Liraglutide } 3.0 \mathrm{mg} \text { resulted in (when } \\
\text { compared to placebo) greater AHI mean } \\
\text { reduction }(-12.2 \text { vs. }-6.1 \text { events } / \mathrm{h}, \\
\text { estimated treatment difference } \\
-6.1 \text { events } / \mathrm{h}[95 \% \mathrm{CI}-11.0 \\
\text { to }-1.2] ; P=0.0150) \text {; greater mean } \\
\text { reduction in weight }(-5.7 \% \text { vs. }-1.6 \% \text {, } \\
\text { estimated treatment difference }-4.2 \% \\
{[95 \% \mathrm{CI}-5.2 \text { to }-3.1 \%], P<0.0001 \text { ); }} \\
\text { greater reductions in HbAlc levels and } \\
\text { SBP (both } P<0.001 \text { ) }\end{array}$ \\
\hline
\end{tabular}

$A H I$ apnoea-hypopnoea index, GLP-1 RA glucagon-like peptide-1 receptor agonist, $H b A 1 c$ glycated haemoglobin, $O S A$ obstructive sleep apnoea, $S B P$ systolic blood pressure, $S C A L E$ satiety and clinical adiposity-liraglutide evidence in individuals with and without diabetes

Table 26 Guidelines for the use of GLP-1 RAs during Ramadan

\begin{tabular}{ll}
\hline Situation in pre-Ramadan & Action during Ramadan \\
\hline $\begin{array}{l}\text { Single dose before breakfast. Exenatide may be used twice } \\
\text { within } 1 \mathrm{~h} \text { before meal }\end{array}$ & $\begin{array}{c}\text { Same dose to be taken before Iftar. Exenatide same as pre- } \\
\text { Ramadan before Iftar/or Sahur }\end{array}$ \\
\hline
\end{tabular}

Guidelines are for GLP-1RAs: liraglutide 0.6/1.2/1.8 mg, lixisenatide 10/20 $\mu \mathrm{g}$ and exenatide 5/10 $\mu \mathrm{g}$

GLP-1 RA glucagon-like peptide-1 receptor agonist

\section{Patient-Related Factors}

Psychosocial factors that affect the selection of GLP-1 RAs include the ability of the patient to self-inject, their meal patterns and adherence to the pre-specified time of injection, frequency of contact with healthcare providers, cost-effectiveness and so on [214].

For a person who can self-inject, all GLP-1 RAs are equally feasible for use. Certain GLP-1 RAs require manual dexterity as a few of them need needle attachment, reconstitution and priming prior to injection. Injection frequency, discussed in a forthcoming section, is another important factor. The injection frequencies among GLP-1 analogues vary from twice-daily to once-weekly administration owing to different pharmacological profiles [214].

Meal patterns may also influence the choice of GLP-1 analogues. Liraglutide is effective with all kinds of meal patterns adopted by patients. Exenatide BID may benefit patients who consume heavy breakfast and dinner, whereas those who take a light dinner may benefit from lixisenatide. Patients with irregular meal patterns and lifestyle who are at risk of hypoglycaemia may benefit from once-weekly drugs without major safety concerns [214].

Another important psychosocial aspect is the cost associated with GLP-1 analogues. Currently, none of the agents are available generically and therefore all GLP-1 analogues have a relatively high cost $[178,214]$.

A few GLP-1 analogues have, however, demonstrated treatment satisfaction versus a few comparators such as sulfonylureas, insulin and DPP4 inhibitors [217-219]. 


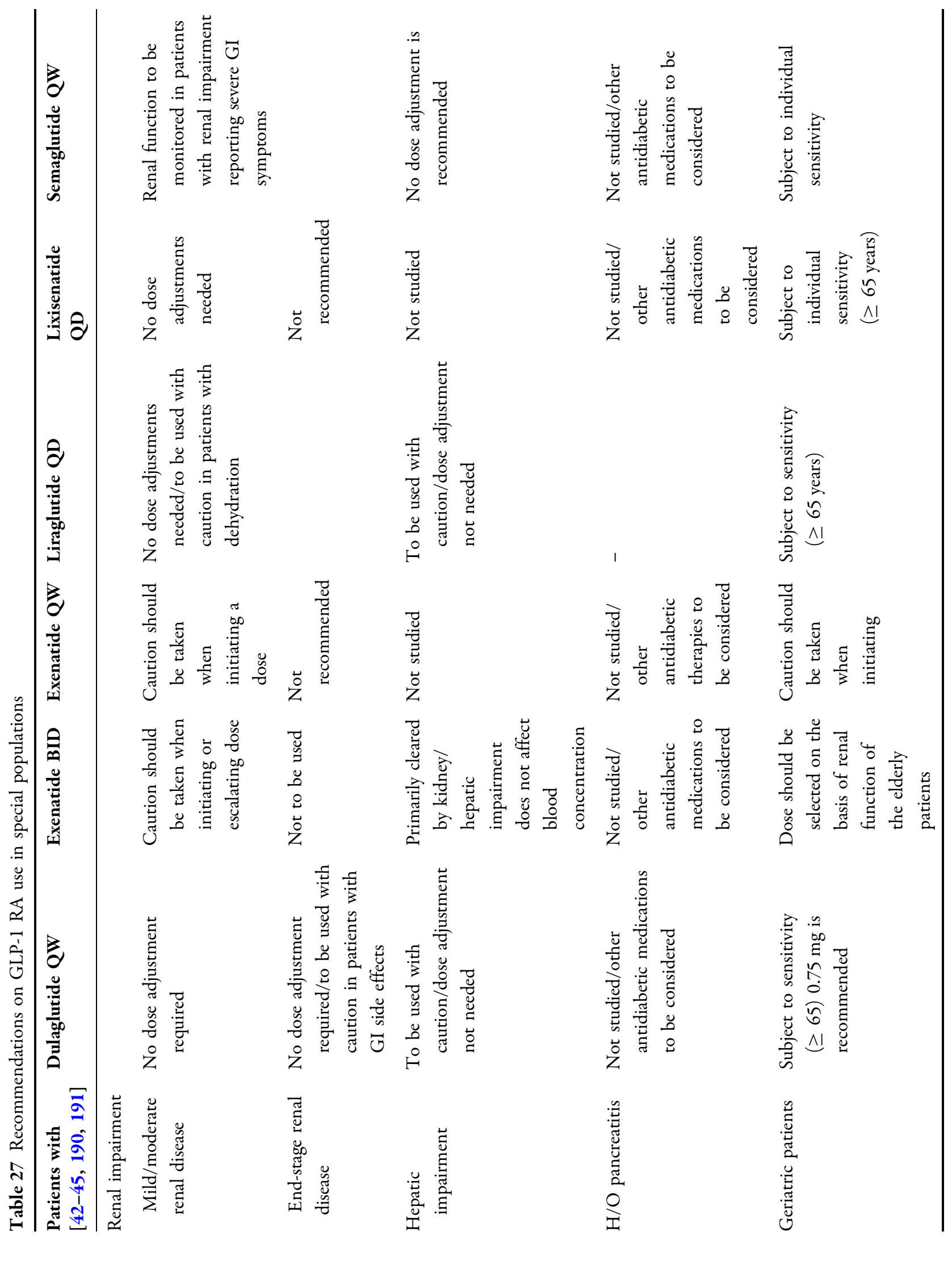




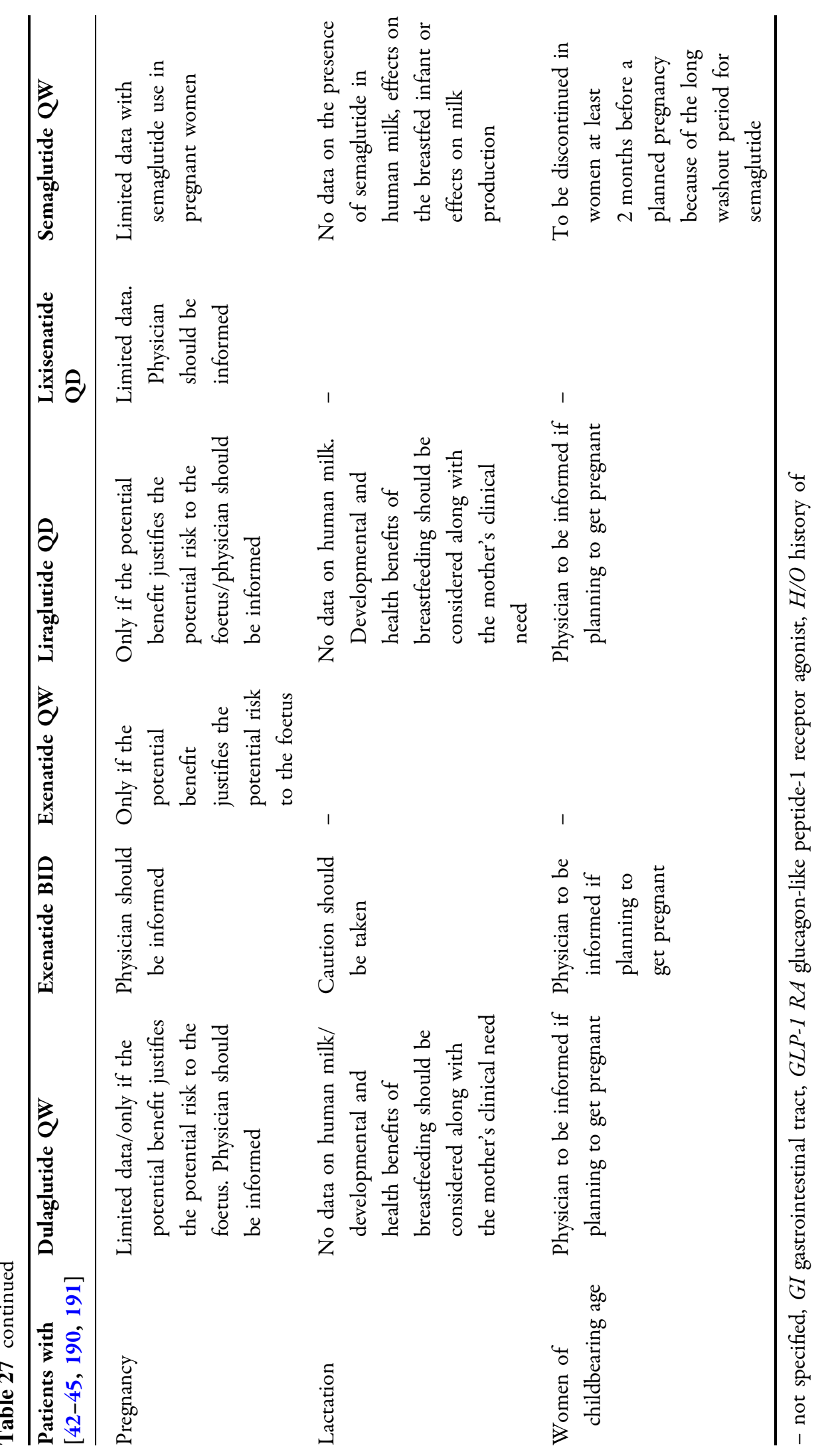




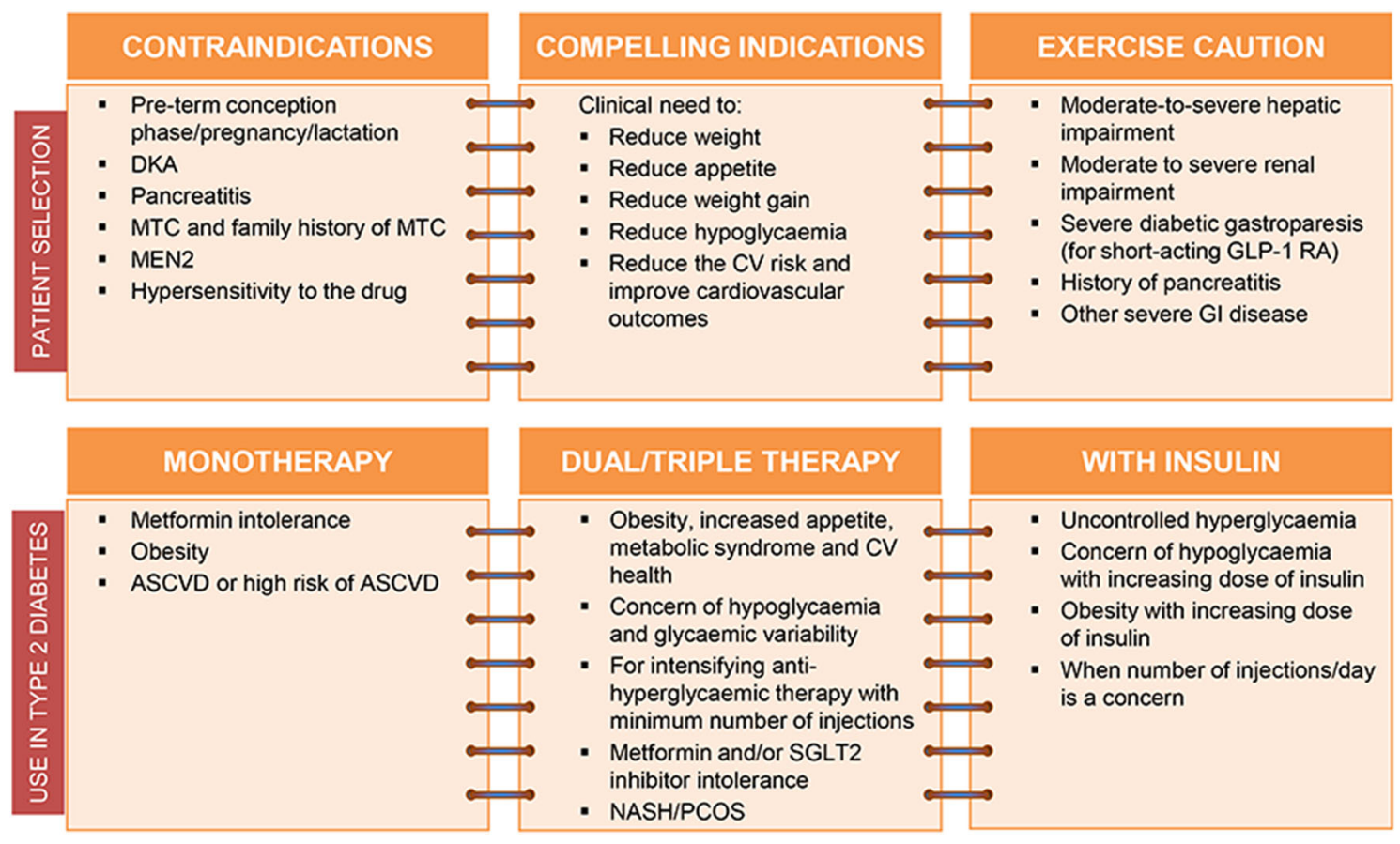

Fig. 4 Patient selection and rationale for GLP-1 RA therapy initiation. $A S C V D$ atherosclerotic cardiovascular disease, $C V$ cardiovascular, $D K A$ diabetic ketoacidosis, $G I$ gastrointestinal, GLP-1 $R A$ glucagon-like peptide-1 receptor agonist,
MEN2 multiple endocrine neoplasia, $M T C$ medullary thyroid carcinoma, $N A S H$ non-alcoholic steatohepatitis, PCOS polycystic ovary syndrome, $S G L T 2$ sodium-glucose co-transporter-2

Table 28 Selection of appropriate GLP-1 RA

\begin{tabular}{|c|c|c|c|}
\hline \multirow[t]{2}{*}{ Parameters } & \multicolumn{3}{|l|}{ GLP-1 RA } \\
\hline & Short-acting & Intermediate-acting & $\overline{\text { Long-acting }}$ \\
\hline \multicolumn{4}{|l|}{ Glycaemia } \\
\hline FBG & + & ++ & +++ \\
\hline PPBG & +++ & ++ & ++ \\
\hline Weight & ++ & +++ & +++ \\
\hline $\mathrm{CVO}$ & + & +++ & +++ \\
\hline Injection burden & +++ & ++ & + \\
\hline Renal safety & + & ++ & ++ \\
\hline GI intolerance & +++ & ++ & + \\
\hline
\end{tabular}

The number of ' + ' signs indicates the weighting for consideration of the parameter for respective therapy $C V O$ cardiovascular outcomes, $F B G$ fasting blood glucose, $G I$ gastrointestinal, $G L P-1$ RA glucagon-like peptide-1 receptor agonist, $P P B G$ postprandial blood glucose 


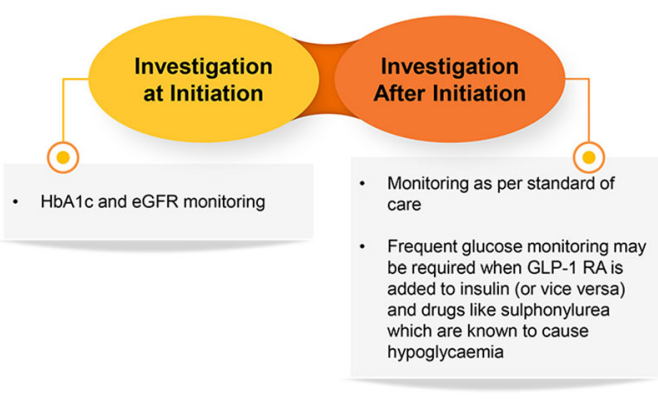

Note: Routing serum amylase/lipase monitoring, renal/hepatic function monitoring and serum calcitonin monitoring/thyroid ultrasound after therapy initiation is not indicated/required.

Fig. 5 Monitoring checklist for GLP-1 RA-based therapy. eGFR estimated glomerular filtration rate, GLP-1 RA glucagon-like peptide-1 receptor agonist, $H b A l c$ glycated haemoglobin

\section{Selection of Appropriate GLP-1 Analogue}

The efficacy and safety profiles vary among the GLP-1 RAs because of their varying pharmacokinetic profiles. Hence, GLP-1 RAs can be chosen on the basis of the clinical need of the patients. Table 28 illustrates the selection criteria based on the efficacy of GLP-1 RAs to act upon a clinical parameter.

\section{Monitoring Checklist Specific for GLP-1 RA-Based Therapy}

Proactive monitoring aids in improving therapeutic outcomes and preventing potential adverse drug effects. It provides essential information for the management of chronic conditions such as diabetes to both healthcare providers and patients. Figure 5 lists the recommended procedures, lab tests and physical assessments to be performed or reviewed before and after the initiation of GLP-1 RA therapy.

\section{Injection Technique and Frequency}

One of the main advantages of GLP-1 RAs with respect to mode of administration is the readyto-use pens which improve adherence to therapy. Studies have reported favourable patient outcomes with pen delivery systems compared to vial or syringe systems [220, 221]. Table 29 compares the injection pens and delivery patterns of GLP-1 RAs.

Dulaglutide has a hidden, ready-attached needle which requires no priming; this may help patients with fear of needles [223]. Onceweekly doses reduce the injection burden on patients who are unwilling to self-inject, have aversion to needles and are unable to adhere to frequently administered therapy. This also helps patients who depend on caregivers for injections. Dulaglutide and semaglutide require once-weekly doses owing to their extended duration of action [223]. Such once-weekly injections can also be administered as directly observed therapy which encourages regular patient-provider contact.

\section{Combinations of GLP-1 RA and Insulin}

As discussed earlier, many guidelines across the world recommend GLP-1 RAs along with insulin. Given the versatility of GLP-1 RAs, the rationale behind combining basal insulin with GLP-1 RAs is the fact that combination optimises the prandial endogenous insulin response to control PPBG and reduces the insulin dose requirement [228]. Their complementary modes of action are known to improve glycaemic control in many patients with T2DM with no significant risk of hypoglycaemia and weight gain [229]. In addition, fixed-ratio combination has the advantage of a less complex treatment regimen, with only one injection per day.

The USFDA has currently approved two titratable, fixed-ratio combination therapies for the treatment of patients with T2DM [230]. Table 30 presents the fixed-ratio combination of insulin/GLP-1 RA currently available on the market along with the clinical evidence available on combination therapy.

\section{Quality of Life: GLP-1 RA-Based Therapy}

Quality of life associated with GLP-1 RA-based therapy is presented in an evidence-based manner as follows:

A study examined and compared patient perceptions of the injection devices used with liraglutide and dulaglutide. Patients with T2DM 
Table 29 Comparison of injection pens and delivery patterns of GLP-1 RAs

\begin{tabular}{|c|c|c|c|c|c|c|}
\hline $\begin{array}{l}\text { Parameters } \\
\text { GLP-1 RA }\end{array}$ & Delivery devices & $\begin{array}{l}\text { Time to } \\
\text { steady } \\
\text { state }^{a^{a}}\end{array}$ & $\begin{array}{l}\text { Administration } \\
\text { frequency }^{\text {b }}\end{array}$ & $\begin{array}{l}\text { Need to } \\
\text { attach } \\
\text { needle } \\
\text { to pen }\end{array}$ & $\begin{array}{l}\text { Need } \\
\text { to } \\
\text { prime } \\
\text { pen? }\end{array}$ & $\begin{array}{l}\text { Reconstitution } \\
\text { requirement }\end{array}$ \\
\hline $\begin{array}{l}\text { Dulaglutide } \\
\quad[222,223]\end{array}$ & $\begin{array}{l}\text { Single-dose prefilled pen }(0.75 \mathrm{mg} \text {, } \\
1.5 \mathrm{mg})\end{array}$ & $2-4$ weeks & Once weekly & No & No & No \\
\hline $\begin{array}{l}\text { Exenatide } \\
\text { BID } \\
{[223,224]}\end{array}$ & $\begin{array}{l}\text { Multi-dose prefilled pens } \\
\qquad(5 \mu \mathrm{g} / \text { dose }, 10 \mu \mathrm{g} / \text { dose })\end{array}$ & $\begin{array}{l}\text { Not } \\
\text { reported }\end{array}$ & Twice daily & Yes & Yes & No \\
\hline $\begin{array}{l}\text { Exenatide } \\
\qquad \text { QW } \\
{[223,225]}\end{array}$ & $\begin{array}{l}\text { Single-dose, dual-chamber pen } \\
\text { containing powder }(2 \mathrm{mg}) \text { and } \\
\text { solvent for prolonged-release } \\
\text { suspension and single-dose } \\
\text { prefilled pen for prolonged-release } \\
\text { suspension }(2 \mathrm{mg})\end{array}$ & 6-7 weeks & Once weekly & Yes & No & Yes \\
\hline $\begin{array}{l}\text { Liraglutide } \\
\qquad[223,226]\end{array}$ & $\begin{array}{l}\text { Multi-dose prefilled pen (device } \\
\text { delivers } 0.6,1.2 \text { or } 1.8 \mathrm{mg} / \text { dose })\end{array}$ & $\begin{array}{l}\text { Not } \\
\text { reported }\end{array}$ & Once daily & Yes & Yes & No \\
\hline $\begin{array}{l}\text { Lixisenatide } \\
{[223,227]}\end{array}$ & $\begin{array}{l}\text { Multi-dose prefilled pens } \\
\qquad(10 \mu \mathrm{g} / \text { dose, } 20 \mu \mathrm{g} / \text { dose })^{\mathrm{c}}\end{array}$ & $\begin{array}{l}\text { Not } \\
\text { reported }\end{array}$ & Once daily & Yes & Yes & No \\
\hline $\begin{array}{l}\text { Semaglutide } \\
\quad[50,51]\end{array}$ & $\begin{array}{l}\text { Multi-dose prefilled pens (device } \\
\text { delivers } 0.25,0.5 \text { and } 1 \mathrm{mg} / \text { dose) }\end{array}$ & 4-5 weeks & Once weekly & Yes & Yes & No \\
\hline
\end{tabular}

All the above drugs should be refrigerated between 2 and $8{ }^{\circ} \mathrm{C}$ before their first use. Not to be kept in freezer and not be used if frozen. The devices should be protected from heat and sunlight

GLP-1 RA glucagon-like peptide-1 receptor agonist

a Approximate values

b All GLP-1 receptor agonists administered subcutaneously

c Also available as a treatment-initiation pack containing both doses of multi-dose prefilled pens

across the USA $(N=404$, mean age $=60.7$ years, 54.0\% female; 204 liraglutide; 200 dulaglutide) were recruited for the study. Patients who had experience with both the treatments completed the Diabetes Injection Device Preference Questionnaire (DID-PQ) to report preferences between the two devices. Analysis of covariance was used to compare Diabetes Injection Device Experience Questionnaire (DID-EQ) scores. Although the mean DID-EQ item scores for both treatments were high (ranging from 3.48 to 3.90 on a 4-point scale), it was demonstrated that dulaglutide had higher scores than liraglutide on DID-EQ global items, which assessed the ease of use (3.82 vs. 3.73, $P=0.040)$ and convenience $(3.79$ vs. $3.66, P=0.004)$.
Among the 58 patients who had used both devices, more patients reported a preference for the dulaglutide device than the liraglutide device on every item of the DID-PQ [237].

A study on the safe and effective use of dulaglutide single-dose pen in injection-naïve patients with T2DM reported that the majority of patients $(>96 \%)$ found the device easy to use. They were satisfied with the pen, and were willing to continue and recommend the pen to others. A significant reduction in the fear of selfinjection from baseline to the end of the study was also reported [238].

Another prospective, observational study analysed the changes in health-related quality of life and emotional well-being in patients who 


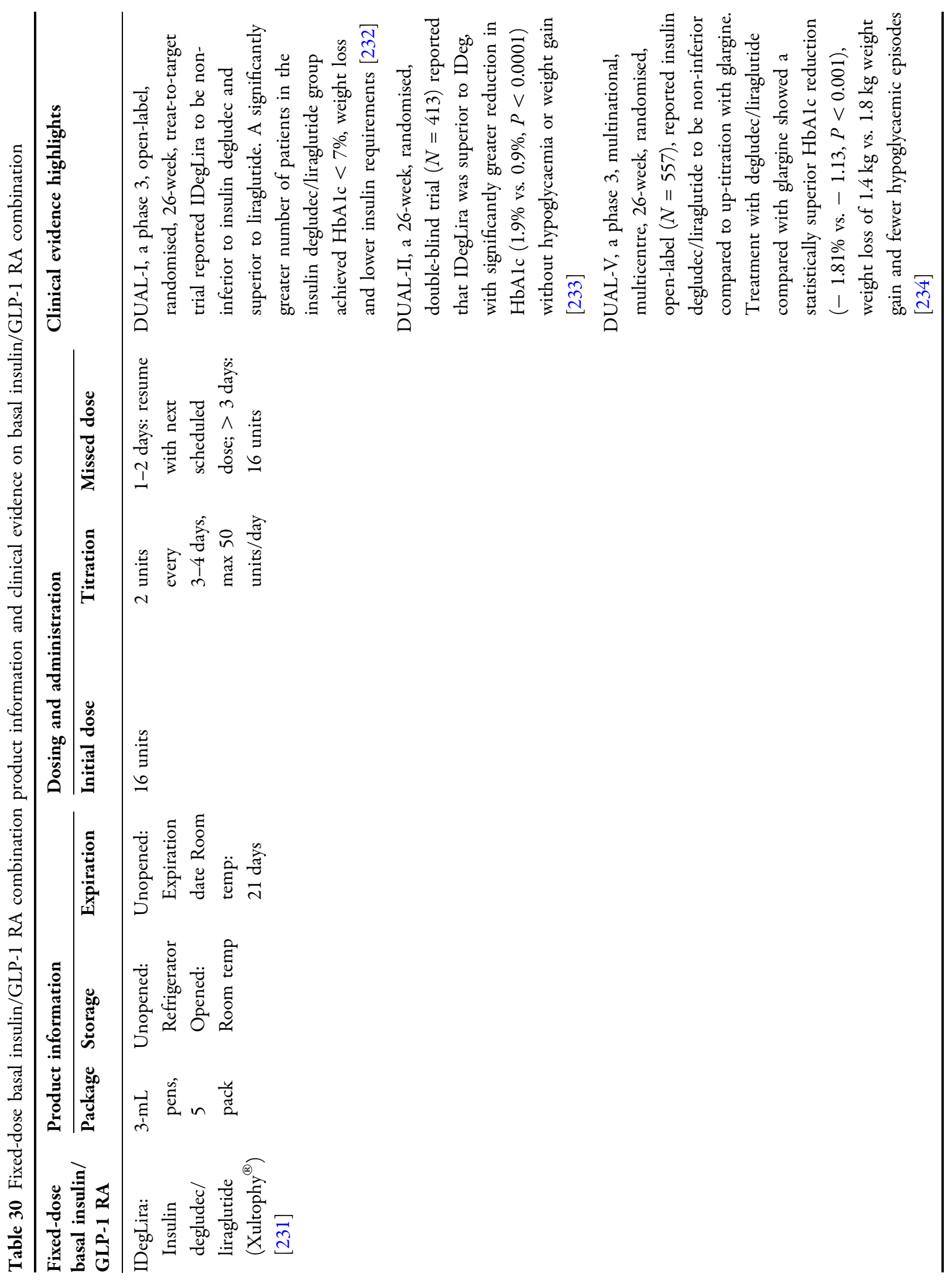




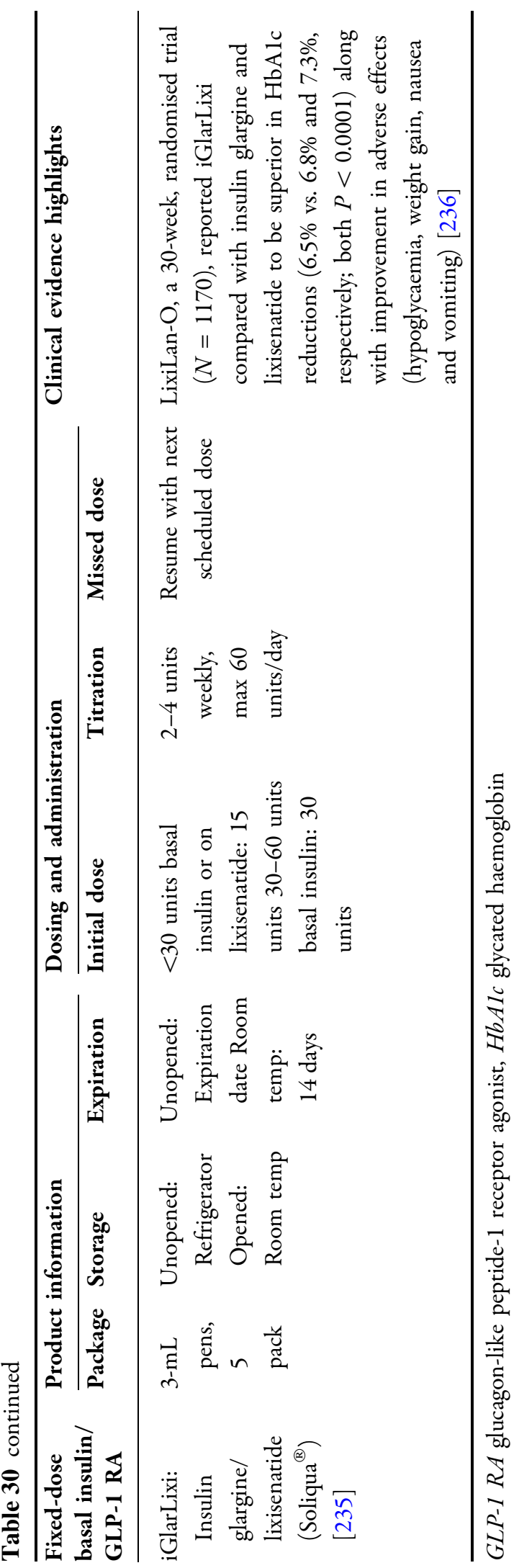

had commenced GLP-1 analogue therapy (exenatide) in comparison with new insulin starters. At 6 months, the patient group treated with exenatide experienced significantly greater treatment satisfaction $(P<0.05)$, well-being $(P<0.05)$ and reduced hospital anxiety and depression scale scores $(P<0.05)$ compared to the insulin-treated group. Results from multivariate analysis showed a cumulative significant effect $(P<0.05)$ of exenatide analogue therapy on diabetes treatment satisfaction questionnaire and Well-Being Questionnaire 12 scores after controlling for the effect of BMI [218].

Treatment satisfaction and improvement in the quality of life influence adherence to medications. A series of randomised trials assessed once-weekly administration of dulaglutide as an add-on therapy in patients with T2DM. The study reported improvement in perceived hypoglycaemia and treatment satisfaction as assessed by Diabetes Treatment Satisfaction Questionnaire (DTSQ) status and change version compared to placebo and exenatide BID at 26 and 52 weeks [239].

A 52-week randomised, parallel-group, openlabel trial compared the efficacy and safety of once-daily human GLP-1 analogue liraglutide (1.2 or $1.8 \mathrm{mg}$ ) with DPP4 inhibitor sitagliptin, added onto metformin in individuals with T2DM. DTSQ scores increased significantly $(P=0.03)$ more with liraglutide $(1.8 \mathrm{mg})$ than with sitagliptin [217].

A 52-week randomised, double-blind controlled trial investigated the patient-reported outcomes which included psychological wellbeing and distress in addition to other factors following treatment with liraglutide (1.2 or $1.8 \mathrm{mg}$ ) or glimepiride monotherapies in patients with T2DM. Glycaemic control and weight reduction were significantly greater in patients treated with 1.2 or $1.8 \mathrm{mg}$ liraglutide $(P<0.0001)$ compared to glimepiride which resulted in weight gain. Mental and emotional health, and general perceived health improved more with liraglutide $(1.8 \mathrm{mg})$ than with glimepiride [219]. 


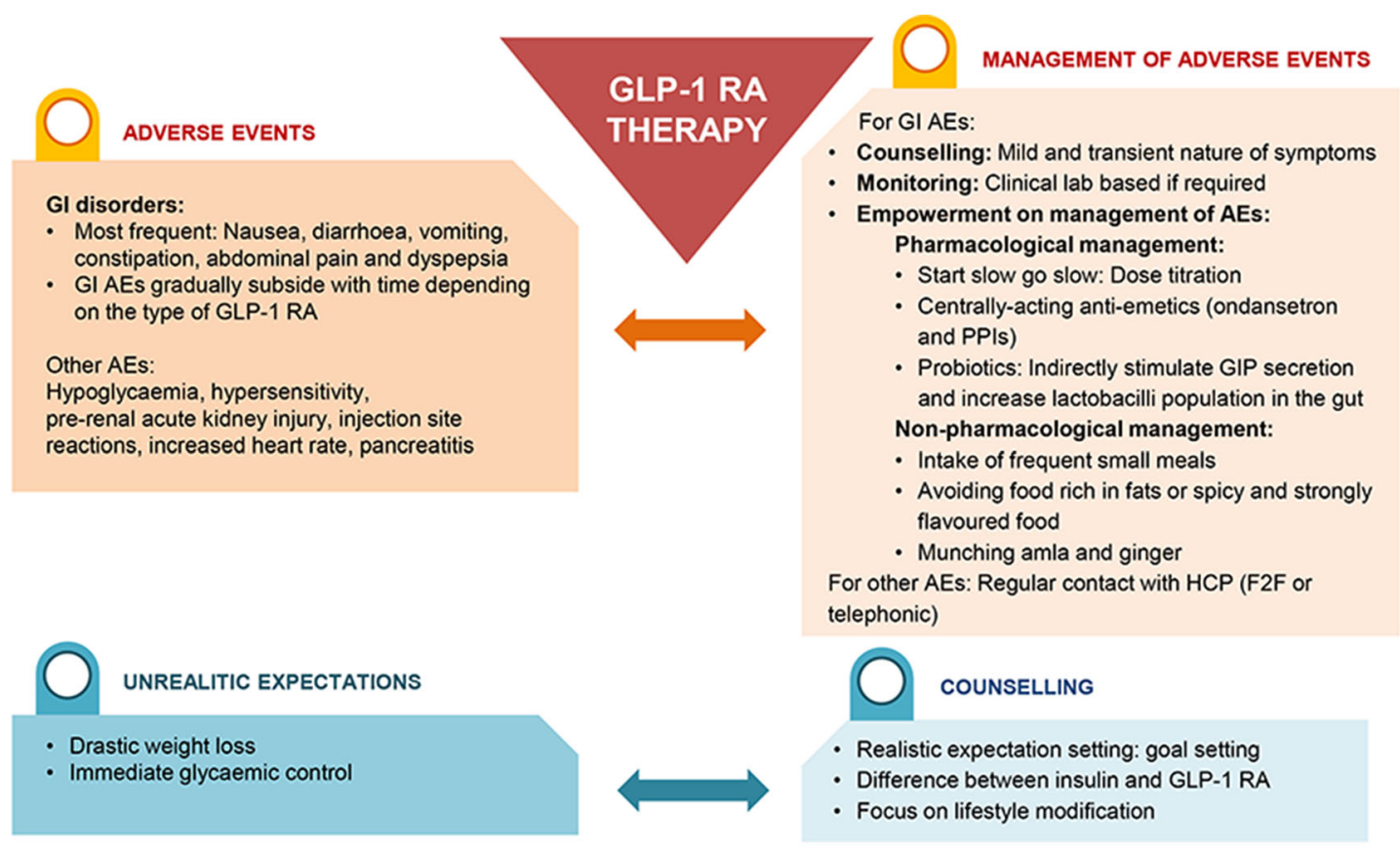

Fig. 6 Barriers to bridges in GLP-1 RA therapy. AEs adverse events, $F 2 F$ face-to-face, GI gastrointestinal, GIP glucosedependent insulinotropic polypeptide, GLP-1 RA glucagon-like peptide-1 receptor agonist, $H C P$ healthcare practitioner, $P P I$ proton pump inhibitor

\section{Cost Implications}

Cost-effectiveness plays a major role from the South Asian perspective wherein out-of-pocket health expenditure is witnessed by patients without any aid from the government [240, 241]. Listing GLP-1 RAs in the national list of essential medicines may reduce financial burden and pave the way for insurance benefits.

\section{Barriers to Bridges: GLP-1 RA Therapy}

Adverse events associated with GLP-1 RAs are one of the major barriers for adherence to the therapy. The AEs most frequently associated with GLP-1 RAs are GI disorders, as evident from clinical trials and real-world studies [242-244]. The GI symptoms are reported to gradually subside with time and are dependent on the kind of GLP-1 RAs administered (short- or longacting) [39]. GI AEs may not affect glycaemic control but may be associated with greater weight loss [245]. Among the GI symptoms, nausea and diarrhoea were reported to be the most common, followed by vomiting, constipation, abdominal pain and dyspepsia [246]. The incidence of nausea is reported to vary between $25 \%$ and $60 \%$, and its occurrence in specific individuals seems to be dependent on factors such as meal size, frequency and BMI [39]. The other AEs include pre-renal acute injury, hypoglycaemia, injection site reactions, hypersensitivity, increase in heart rate and acute pancreatitis (proven in animal studies) [39, 178, 214, 216, 246, 247].

Counselling patients on mild and transient nature of symptoms, especially GI symptoms, may aid them to deal with unrealistic fears associated with AEs. Additionally, patient counselling about realistic expectations from the therapy may improve adherence to the therapy. The barriers associated with GLP-1 RAbased therapy and the ways to mitigate these barriers are presented in Fig. 6 .

Directly observed therapy (DOT) is an approach that facilitates patients to self-inject in the presence of a diabetes educator. This 
method is advantageous for both patient and the practitioner supporting the patient. It encourages regular patient-provider contact, which in turn facilitates early detection of AEs and complications and promotes more efficient lifestyle modifications [22].

\section{CONCLUSIONS}

GLP-1 RAs, recognised as calorie restriction mimetics or calorie restriction facilitators, are relatively a newer class of injectable drugs in the pharmacological armamentarium for the management of T2DM. With benefits extending beyond glucose control, GLP-1 RAs are associated with extra-glycaemic effects including positive effects on weight, BP, cholesterol levels and $\beta$-cell function. Fortuitously, increasing evidence from large clinical trials aimed at studying CV episodes has also demonstrated CV risk reduction with GLP-1 RAs. The REWIND trial is anticipated to resolve the long-standing question on whether this class of drug could be beneficial in patient populations without an established CVD as their usefulness in patients with established CVD had already been demonstrated with a wealth of evidence. As GLP-1 RA therapy initiation is largely influenced by clinical requisites of patients, it is imperative that a pragmatic review of current evidence be integrated and applied in the context of an individualised patient-centred approach. However, there are quite a few unanswered questions on GLP-1 RAs such as long-term durability of their glycaemic effect, recommendation in the current cascade of therapy for T2DM, long-term safety concerns and so on. It is anticipated that the ongoing trials, in an evidence-based manner, will continue to fill these gaps and bring new paradigm shifts in diabetes care.

\section{ACKNOWLEDGEMENTS}

Funding. No funding or sponsorship was received for this study or publication of this article.
Medical Writing and Editorial Assistance. The authors acknowledge Preethi Seshadri, PhD, and Rajani Salunke, PhD, of Indegene Pvt. Ltd. for their writing assistance and editorial inputs. This was funded by Eli Lilly, India.

Authorship. All named authors meet the International Committee of Medical Journal Editors (ICMJE) criteria for authorship for this article, take responsibility for the integrity of the work as a whole, and have given their approval for this version to be published.

Disclosures. Dr. Sanjay Kalra has received speaker fees from Eli Lilly, Novo Nordisk and Sanofi Aventis. Ashok Kumar Das, Rakesh Kumar Sahay, Manash Pratim Baruah, Mangesh Tiwaskar, Sambit Das, Sudip Chatterjee, Banshi Saboo, Ganapathi Bantwal, Saptarshi Bhattacharya, Gagan Priya, Manoj Chawla, Kiraninder Brar, Syed Abbas Raza, Azizul Hasan Aamir, Dina Shrestha, Noel Somasundaram, Prasad Katulanda, Faria Afsana, Shahjada Selim, Mohammad Wali Naseri, Ali Latheef and Manilka Sumanatilleke have nothing to disclose.

Compliance with Ethics Guidelines. This article is based on previously conducted studies and does not contain any studies with human participants or animals performed by any of the authors.

Data Availability. No data were analysed in the study. Data from already published studies is presented in this review.

Open Access. This article is distributed under the terms of the Creative Commons Attribution-NonCommercial 4.0 International License (http://creativecommons.org/licenses/ by-nc/4.0/), which permits any noncommercial use, distribution, and reproduction in any medium, provided you give appropriate credit to the original author(s) and the source, provide a link to the Creative Commons license, and indicate if changes were made. 


\section{REFERENCES}

1. International Diabetes Federation. IDF diabetes atlas. 8th edn. http://www.diabetesatlas.org/ resources/2017-atlas.html. Accessed 15 May 2018.

2. Kooner JS, Saleheen D, Sim X, et al. Genome-wide association study in individuals of South Asian ancestry identifies six new type 2 diabetes susceptibility loci. Nat Genet. 2011;43(10):984-9.

3. Ramachandran A, Ma RC, Snehalatha C. Diabetes in Asia. Lancet. 2010;375(9712):408-18.

4. International Diabetes Foundation. IDF Diabetes Atlas. 8th edn. http://www.diabetesatlas.org/ resources/2017-atlas.html. Accessed 13 Jun 2018.

5. Behl S, Misra A. Management of obesity in adult Asian Indians. Indian Heart J. 2017;69(4):539-44.

6. Helble M, Francisco K. The imminent obesity crisis in Asia and the Pacific: first cost estimates. ADBI Working Paper 743. Tokyo: Asian Development Bank Institute; 2017.

7. Joshi SR. Diabetes care in India. Ann Glob Health. 2015;81(6):830-8.

8. Shelgikar KM, Hockaday TD, Yajnik CS. Central rather than generalized obesity is related to hyperglycaemia in Asian Indian subjects. Diabetes Med. 1991;8(8):712-7.

9. Kalra S, Unnikrishnan AG. Obesity in India: the weight of the nation. J Med Nutr Nutraceut. 2012;1(1):37-41.

10. Misra A, Shrivastava U. Obesity and dyslipidemia in South Asians. Nutrients. 2013;5(7):2708-33.

11. McKeigue PM, Shah B, Marmot MG. Relation of central obesity and insulin resistance with high diabetes prevalence and cardiovascular risk in South Asians. Lancet. 1991;337(8738):382-6.

12. Pappachan JM, Viswanath AK. Medical management of diabesity: do we have realistic targets? Curr Diabetes Rep. 2017;17(1):4.

13. Sims EA, Danforth E Jr, Horton ES, Bray GA, Glennon JA, Salans LB. Endocrine and metabolic effects of experimental obesity in man. Recent Prog Horm Res. 1973;29:457-96.

14. Chadt A, Scherneck S, Joost HG, Al-Hasani H. Molecular links between obesity and diabetes: "diabesity". In: Feingold KR, Anawalt B, Boyce A, et al., editors. Endotext [Internet]. South Dartmouth (MA): MDText.com, Inc.; 2000.
15. Norris SL, Zhang X, Avenell A, et al. Efficacy of pharmacotherapy for weight loss in adults with type 2 diabetes mellitus: a meta-analysis. Arch Intern Med. 2004;164(13):1395-404.

16. Zimmet PZ. Diabetes and its drivers: the largest epidemic in human history? Clin Diabetes Endocrinol. 2017;3:1.

17. Hsia DS, Grove O, Cefalu WT. An update on sodium-glucose co-transporter- 2 inhibitors for the treatment of diabetes mellitus. Curr Opin Endocrinol Diabetes Obes. 2017;24(1):73-9.

18. Larsson H, Holst JJ, Ahren B. Glucagon-like peptide1 reduces hepatic glucose production indirectly through insulin and glucagon in humans. Acta Physiol Scand. 1997;160(4):413-22.

19. Meier JJ, Gallwitz B, Salmen S, et al. Normalization of glucose concentrations and deceleration of gastric emptying after solid meals during intravenous glucagon-like peptide 1 in patients with type 2 diabetes. J Clin Endocrinol Metab. 2003;88(6):2719-25.

20. Nauck MA, Niedereichholz U, Ettler R, et al. Glucagon-like peptide 1 inhibition of gastric emptying outweighs its insulinotropic effects in healthy humans. Am J Physiol. 1997;273(5 Pt 1):E981-8.

21. Turton MD, O'Shea D, Gunn I, et al. A role for glucagon-like peptide- 1 in the central regulation of feeding. Nature. 1996;379(6560):69-72.

22. Kalra S, Baruah MP, Sahay RK, Unnikrishnan AG, Uppal S, Adetunji O. Glucagon-like peptide-1 receptor agonists in the treatment of type 2 diabetes: past, present, and future. Indian J Endocrinol Metab. 2016;20(2):254-67.

23. Chatterjee S, Ghosal S, Chatterjee S. Glucagon-like peptide-1 receptor agonists favorably address all components of metabolic syndrome. World J Diabetes. $2016 ; 7(18): 441-8$.

24. Nauck MA, Heimesaat MM, Behle K, et al. Effects of glucagon-like peptide 1 on counterregulatory hormone responses, cognitive functions, and insulin secretion during hyperinsulinemic, stepped hypoglycemic clamp experiments in healthy volunteers. J Clin Endocrinol Metab. 2002;87(3):1239-46.

25. Handelsman Y, Bloomgarden ZT, Grunberger G, et al. American Association of Clinical Endocrinologists and American College of Endocrinology Clinical practice guidelines for developing a diabetes mellitus comprehensive care plan - 2015 . Endocr Pract. 2015;21(Suppl 1):1-87.

26. Holst JJ, Vilsboll T, Deacon CF. The incretin system and its role in type 2 diabetes mellitus. Mol Cell Endocrinol. 2009;297(1-2):127-36. 
27. Ceccarelli E, Guarino EG, Merlotti D, et al. Beyond glycemic control in diabetes mellitus: effects of incretin-based therapies on bone metabolism. Front Endocrinol (Lausanne). 2013;4:73.

28. Ahren B. Incretin hormones and the up-regulation of insulin secretion in insulin resistance. JCEM. 2012;97(4):1173-5.

29. Cariou B. Pleiotropic effects of insulin and GLP-1 receptor agonists: potential benefits of the association. Diabetes Metab. 2015;41(6 Suppl 1):6S28-35.

30. Gastaldelli A, Marchesini G. Time for glucagon like peptide-1 receptor agonists treatment for patients with NAFLD? J Hepatol. 2016;64(2):262-4.

31. Holst JJ. The physiology of glucagon-like peptide 1 . Physiol Rev. 2007;87(4):1409-39.

32. Seino Y, Fukushima M, Yabe D. GIP and GLP-1, the two incretin hormones: similarities and differences. J Diabetes Investig. 2010;1(1-2):8-23.

33. Sandoval DA, D'Alessio DA. Physiology of proglucagon peptides: role of glucagon and GLP-1 in health and disease. Physiol Rev. 2015;95(2):513-48.

34. Seino Y, Terauchi Y, Osonoi T, et al. Safety and efficacy of semaglutide once weekly vs sitagliptin once daily, both as monotherapy in Japanese people with type 2 diabetes. Diabetes Obes Metab. 2018;20(2):378-88.

35. Wettergren A, Petersen H, Orskov C, Christiansen J, Sheikh SP, Holst JJ. Glucagon-like peptide-1 7-36 amide and peptide YY from the L-cell of the ileal mucosa are potent inhibitors of vagally induced gastric acid secretion in man. Scand J Gastroenterol. 1994;29(6):501-5.

36. Van Bloemendaal L, Ten Kulve JS, La Fleur SE, Ijzerman RG, Diamant M. Effects of glucagon-like peptide 1 on appetite and body weight: focus on the CNS. J Endocrinol. 2014;221(1):T1-16.

37. Wang Q, Brubaker PL. Glucagon-like peptide-1 treatment delays the onset of diabetes in 8 week-old $\mathrm{db} / \mathrm{db}$ mice. Diabetologia. 2002;45(9):1263-73.

38. Farilla L, Hui H, Bertolotto C, et al. Glucagon-like peptide-1 promotes islet cell growth and inhibits apoptosis in Zucker diabetic rats. Endocrinology. 2002;143(11):4397-408.

39. Meier JJ. GLP-1 receptor agonists for individualized treatment of type 2 diabetes mellitus. Nat Rev Endocrinol. 2012;8(12):728-42.

40. Sonia TA, Sharma CP. Diabetes mellitus - an overview. In: Oral delivery of insulin. Cambridge: Woodhead; 2014. p. 1-57.
41. Kalra S, Saboo B. Exenatide implant therapy in diabetes. J Pak Med Assoc. 2018;68:1538-40.

42. Trulicity (dulaglutide) injection, for subcutaneous use: highlights of prescribing information, TRU0007-USPI-20170825. 2019. https://pi.lilly.com/us/ trulicity-uspi.pdf. Accessed 5 Oct 2018.

43. Byetta ${ }^{\circledR}$ (exenatide) injection: highlights of prescribing information, 823011-CC. 2009. https:// www.accessdata.fda.gov/drugsatfda_docs/label/2009/ 021773s9s11s18s22s25lbl.pdf. Accessed 5 Oct 2018.

44. Bydureon, Exenatide extended-release for injectable suspension, for subcutaneous use: highlights of prescribing information. 2018. https:// www.accessdata.fda.gov/drugsatfda_docs/label/2018/ 022200s026lbl.pdf. Accessed 5 Oct 2018.

45. Victoza ${ }^{\circledR}$ (Liraglutide [rDNA origin] injection), solution for subcutaneous use: highlights of prescribing information, 1-877-484-2869. 2010.https:// www.accessdata.fda.gov/drugsatfda_docs/label/ 2010/022341lbl.pdf. Accessed 5 Oct 2018.

46. Schisler J, Lang C. Endocrinology of the heart in health and disease. In: Schisler JC, Lang $\mathrm{CH}$, Willis MS, editors. Academic Press, 2017.

47. Lyxumia injection, solution (Lixisenatide): Product information. 2013. https://www.ema.europa.eu/ en/documents/product-information/lyxumia-eparproduct-information_en.pdf. Accessed 5 Oct 2018.

48. Ozempic ${ }^{\circledR}$ (semaglutide) injection: highlights of prescribing information. 2017. https://www.novopi.com/ozempic.pdf. Accessed 5 Oct 2018.

49. Jensen L, Helleberg H, Roffel A, et al. Absorption, metabolism and excretion of the GLP-1 analogue semaglutide in humans and nonclinical species. Eur J Pharm Sci. 2017;15(104):31-41.

50. Ozempic (Semaglutide): drug summary. 2018. https://www.pdr.net/drug-summary/ Ozempic-semaglutide-24167. Accessed 5 Oct 2018.

51. Comparison of GLP-1 agonists. Pharmacist's letter. therapeuticresearch com 2017. https://pharmacist. therapeuticresearch.com/Content/Segments/PRL/ 2017/Jan/Comparison-of-GLP-1-Agonists-10594. Accessed 15 Oct 2018.

52. Vilsboll T. The effects of glucagon-like peptide-1 on the beta cell. Diabetes Obes Metab. 2009;11(Suppl 3):11-8.

53. European Medicines Agency. Lyxumia: assessment report. 28 November 2012. https://www.ema. europa.eu/documents/assessment-report/lyxumiaepar-public-assessment-report_en.pdf. Accessed 15 Oct 2018. 
54. Trulicity ${ }^{\mathrm{TM}}$ (dulaglutide $0.75 \mathrm{mg}$ and $1.5 \mathrm{mg}$ ) solution for injection: prescribing information. 2015. https://pi.lilly.com/us/trulicity-uspi.pdf. Accessed 5 Oct 2018.

55. Lipscombe L, Booth G, Butalia S, et al. Pharmacologic glycemic management of type 2 diabetes in adults. Can J Diabetes. 2018;42(Suppl 1):S88-103.

56. American Diabetes Association. Standards of medical care in diabetes 2018. https://professional. diabetes.org/content-page/standards-medical-carediabetes. Accessed 10 Jul 2018.

57. Amin HS, Alkadhaib AA, Modahi NH, Alharbi AM, Alkhelaif AA. Physicians' awareness of guidelines concerning diabetes mellitus in primary health care setting in Riyadh KSA. J Taibah Univ Med Sci. 2016;11(4):380-7.

58. Sloan FA, Bethel MA, Lee PP, Brown DS, Feinglos $\mathrm{MN}$. Adherence to guidelines and its effects on hospitalizations with complications of type 2 diabetes. Rev Diabetes Stud. 2004;1(1):29-38.

59. Garber AJ, Abrahamson MJ, Barzilay JI, et al. Consensus statement by the American Association of Clinical Endocrinologists and American College of Endocrinology on the comprehensive type 2 diabetes management algorithm - 2018 executive summary. Endocr Pract. 2018;24(1):91-120.

60. Inzucchi SE, Bergenstal RM, Buse JB, et al. Management of hyperglycemia in type 2 diabetes, 2015: a patient-centered approach: update to a position statement of the American Diabetes Association and the European Association for the Study of Diabetes. Diabetes Care. 2015;38(1):140-9.

61. Niessner A, Tamargo J, Koller L, et al. Non-insulin antidiabetic pharmacotherapy in patients with established cardiovascular disease: a position paper of the European Society of Cardiology working group on cardiovascular pharmacotherapy. Eur Heart J. 2018;39(24):2274-81.

62. Aschner P. New IDF clinical practice recommendations for managing type 2 diabetes in primary care. Diabetes Res Clin Pract. 2017;132:169-70.

63. Type 2 diabetes in adults: management NICE guideline, no. 28. Internal Clinical Guidelines Team. 2015. https://www.nice.org.uk/guidance/ng28/ resources/type-2-diabetes-in-adults-managementpdf-1837338615493. Accessed 5 Oct 2018.

64. Bajaj S. RSSDI clinical practice recommendations for the management of type 2 diabetes mellitus 2017 . Int J Diabetes Dev Ctries. 2018;38(Suppl 1):1-115.

65. Shrestha D, Shrestha P, Sharma S, et al. National consensus statement on the management of type 2 diabetes mellitus in Nepal. J Diabetes Endocrinol Nepal. 2019;3(1):38-57.

66. Pakistan Endocrine Society. Guidelines for the management of type 2 diabetes mellitus in Pakistan. http://www.pakendosociety.org/dmguidelines/. Accessed 4 Oct 2018.

67. Somasundaram N, Wijeyaratne C, De Silva S. Clinical guidelines: the Endocrine Society of Sri Lanka: diabetes mellitus: glucose control. Sri Lanka J Diabetes Endocrinol Metab. 2013;3:45-57.

68. Cornell S. Comparison of the diabetes guidelines from the ADA/EASD and the AACE/ACE. J Am Pharm Assoc. 2003;57(2):261-5.

69. Lipscombe L, Booth G, Butalia S, et al. Pharmacologic glycemic management of type 2 diabetes in adults. Can J Diabetes. 2018;42(Suppl 1):S88-103.

70. Odawara M, Miyagawa J, Iwamoto N, Takita Y, Imaoka T, Takamura T. Once-weekly glucagon-like peptide-1 receptor agonist dulaglutide significantly decreases glycated haemoglobin compared with once-daily liraglutide in Japanese patients with type 2 diabetes: 52 weeks of treatment in a randomized phase III study. Diabetes Obes Metab. 2016;18(3):249-57.

71. Dungan KM, Povedano ST, Forst T, et al. Onceweekly dulaglutide versus once-daily liraglutide in metformin-treated patients with type 2 diabetes (AWARD-6): a randomised, open-label, phase 3, non-inferiority trial. Lancet. 2014;384(9951):1349-57.

72. Ghosal S, Sinha B. Liraglutide and dulaglutide therapy in addition to SGLT-2 inhibitor and metformin treatment in Indian type 2 diabetics: a real world retrospective observational study. Clin Diabetes Endocrinol. 2018;4:11.

73. Drucker DJ, Buse JB, Taylor K, et al. Exenatide once weekly versus twice daily for the treatment of type 2 diabetes: a randomised, open-label, non-inferiority study. Lancet. 2008;372(9645):1240-50.

74. Blevins T, Pullman J, Malloy J, et al. DURATION-5: exenatide once weekly resulted in greater improvements in glycemic control compared with exenatide twice daily in patients with type 2 diabetes. J Clin Endocrinol Metab. 2011;96(5):1301-10.

75. Sheu WH, Brunell SC, Blase E. Efficacy and tolerability of exenatide twice daily and exenatide once weekly in Asian versus White patients with type 2 diabetes mellitus: a pooled analysis. Diabetes Res Clin Pract. 2016;114:160-72.

76. Ji L, Onishi Y, Ahn CW, et al. Efficacy and safety of exenatide once-weekly vs exenatide twice-daily in 
Asian patients with type 2 diabetes mellitus. J Diabetes Investig. 2013;4(1):53-61.

77. Buse JB, Rosenstock J, Sesti G, et al. Liraglutide once a day versus exenatide twice a day for type 2 diabetes: a 26-week randomised, parallel-group, multinational, open-label trial (LEAD-6). Lancet. 2009;374(9683):39-47.

78. Buse JB, Nauck M, Forst T, et al. Exenatide once weekly versus liraglutide once daily in patients with type 2 diabetes (DURATION-6): a randomised, open-label study. Lancet. 2013;381(9861):117-24.

79. Feher M, Vega-Hernandez G, Mocevic E, et al. Effectiveness of liraglutide and lixisenatide in the treatment of type 2 diabetes: real-world evidence from The Health Improvement Network (THIN) database in the United Kingdom. Diabetes Ther. 2017;8(2):417-31.

80. Nauck M, Rizzo M, Johnson A, Bosch-Traberg H, Madsen J, Cariou B. Once-daily liraglutide versus lixisenatide as add-on to metformin in type 2 diabetes: a 26-week randomized controlled clinical trial. Diabetes Care. 2016;39(9):1501-9.

81. Stryker MD, Kane MP, Busch RS. A real-world, observational study of weekly exenatide added to basal insulin in patients with type 2 diabetes mellitus (NCT02895672). Endocrinol Diabetes Metab. 2018;1(1):e00004.

82. McAdam-Marx C, Nguyen H, Schauerhamer MB, et al. Glycemic control and weight outcomes for exenatide once weekly versus liraglutide in patients with type 2 diabetes: a 1-year retrospective cohort analysis. Clin Ther. 2016;38(12):2642-51.

83. Rosenstock J, Raccah D, Koranyi L, et al. Efficacy and safety of lixisenatide once daily versus exenatide twice daily in type 2 diabetes inadequately controlled on metformin: a 24-week, randomized, open-label, active-controlled study (GetGoal-X). Diabetes Care. 2013;36(10):2945-51.

84. Ahmann AJ, Capehorn M, Charpentier G, et al. Efficacy and safety of once-weekly semaglutide versus exenatide ER in subjects with type 2 diabetes (SUSTAIN 3): a 56-week, open-label, randomized clinical trial. Diabetes Care. 2018;41(2):258-66.

85. Zhang L, Zhang M, Zhang Y, Tong N. Efficacy and safety of dulaglutide in patients with type 2 diabetes: a meta-analysis and systematic review. Sci Rep. 2016;8(6):18904.

86. Best JH, Lavillotti K, DeYoung MB, Garrison LP. The effects of exenatide bid on metabolic control, medication use and hospitalization in patients with type 2 diabetes mellitus in clinical practice: a systematic review. Diabetes Obes Metab. 2012;14(5):387-98.

87. Kayaniyil S, Lozano-Ortega G, Bennett HA, et al. A network meta-analysis comparing exenatide once weekly with other GLP-1 receptor agonists for the treatment of type 2 diabetes mellitus. Diabetes Ther. 2016;7(1):27-43.

88. Grimm M, Han J, Weaver C, et al. Efficacy, safety, and tolerability of exenatide once weekly in patients with type 2 diabetes mellitus: an integrated analysis of the DURATION trials. Postgrad Med. 2013;125(3):47-57.

89. Raskin P, Mora PF. Glycaemic control with liraglutide: the phase 3 trial programme. Int J Clin Pract Suppl. 2010;167:21-7.

90. Ostawal A, Mocevic E, Kragh N, Xu W. Clinical effectiveness of liraglutide in type 2 diabetes treatment in the real-world setting: a systematic literature review. Diabetes Ther. 2016;7(3):411-38.

91. Anderson SL, Trujillo JM. Lixisenatide in type 2 diabetes: latest evidence and clinical usefulness. Ther Adv Chronic Dis. 2016;7(1):4-17.

92. Schmidt LJ, Habacher W, Augustin T, Krahulec E, Semlitsch T. A systematic review and meta-analysis of the efficacy of lixisenatide in the treatment of patients with type 2 diabetes. Diabetes Obes Metab. 2014;16(9):769-79.

93. Shi FH, Li H, Cui M, Zhang ZL, Gu ZC, Liu XY. Efficacy and safety of once-weekly semaglutide for the treatment of type 2 diabetes: a systematic review and meta-analysis of randomized controlled trials. Front Pharmacol. 2018;9:576.

94. Kim YG, Hahn S, Oh TJ, Park KS, Cho YM. Differences in the HbA1c-lowering efficacy of glucagonlike peptide- 1 analogues between Asians and nonAsians: a systematic review and meta-analysis. Diabetes Obes Metab. 2014;16(10):900-9.

95. Esposito K, Mosca C, Brancario C, Chiodini P, Ceriello A, Giugliano D. GLP-1 receptor agonists and HBA1c target of $<7 \%$ in type 2 diabetes: metaanalysis of randomized controlled trials. Curr Med Res Opin. 2011;27(8):1519-28.

96. Madsbad S. Review of head-to-head comparisons of glucagon-like peptide-1 receptor agonists. Diabetes Obes Metab. 2016;18(4):317-32.

97. Saraiva FK, Sposito AC. Cardiovascular effects of glucagon-like peptide 1 (GLP-1) receptor agonists. Cardiovasc Diabetol. 2014;22(13):142.

98. Mundil D, Cameron-Vendrig A, Husain M. GLP-1 receptor agonists: a clinical perspective on 
cardiovascular effects. Diab Vasc Dis Res. 2012;9(2):95-108.

99. Umpierrez GE, Pantalone KM, Kwan AY, Zimmermann AG, Zhang N, Fernandez LL. Relationship between weight change and glycaemic control in patients with type 2 diabetes receiving once-weekly dulaglutide treatment. Diabetes Obes Metab. $2016 ; 18(6): 615-22$.

100. Yajima T, Yajima K, Takahashi H, Yasuda K. The effect of dulaglutide on body composition in type 2 diabetes mellitus patients on hemodialysis. J Diabetes Complicat. 2018;32(8):759-63.

101. Klonoff DC, Buse JB, Nielsen LL, et al. Exenatide effects on diabetes, obesity, cardiovascular risk factors and hepatic biomarkers in patients with type 2 diabetes treated for at least 3 years. Curr Med Res Opin. 2008;24(1):275-86.

102. Buse JB, Klonoff DC, Nielsen LL, et al. Metabolic effects of two years of exenatide treatment on diabetes, obesity, and hepatic biomarkers in patients with type 2 diabetes: an interim analysis of data from the open-label, uncontrolled extension of three double-blind, placebo-controlled trials. Clin Ther. 2007;29(1):139-53.

103. Iglesias P, Civantos S, Vega B, Pavon I, Guijarro G, Monereo S. Clinical effectiveness of exenatide in diabetic patients waiting for bariatric surgery. Obes Surg. 2015;25(3):575-8.

104. Viswanathan P, Chaudhuri A, Bhatia R, Al-Atrash F, Mohanty P, Dandona P. Exenatide therapy in obese patients with type 2 diabetes mellitus treated with insulin. Endocr Pract. 2007;13(5):444-50.

105. Jabbour SA, Frias JP, Guja C, Hardy E, Ahmed A, Ohman P. Effects of exenatide once weekly plus dapagliflozin, exenatide once weekly, or dapagliflozin, added to metformin monotherapy, on body weight, systolic blood pressure, and triglycerides in patients with type 2 diabetes in the DURATION-8 study. Diabetes Obes Metab. 2018;20(6):1515-9.

106. Blonde L, Russell-Jones D. The safety and efficacy of liraglutide with or without oral antidiabetic drug therapy in type 2 diabetes: an overview of the LEAD 1-5 studies. Diabetes Obes Metab. 2009;11(Suppl 3):26-34.

107. Davies MJ, Bergenstal R, Bode B, et al. Efficacy of liraglutide for weight loss among patients with type 2 diabetes: the SCALE diabetes randomized clinical trial. JAMA. 2015;314(7):687-99.

108. Gorgojo-Martinez JJ, Feo-Ortega G, Serrano-Moreno C. Effectiveness and tolerability of liraglutide in patients with type 2 diabetes mellitus and obesity after bariatric surgery. Surg Obes Relat Dis. 2016;12(10):1856-63.

109. Ahrén B, Atkin SL, Charpentier G, et al. Semaglutide induces weight loss in subjects with type 2 diabetes regardless of baseline BMI or gastrointestinal adverse events in the SUSTAIN 1 to 5 trials. Diabetes Obes Metab. 2018;20(9):2210-9.

110. Vilsboll T, Christensen M, Junker AE, Knop FK, Gluud LL. Effects of glucagon-like peptide-1 receptor agonists on weight loss: systematic review and meta-analyses of randomised controlled trials. BMJ. 2012;10(344):d7771.

111. Trujillo JM, Nuffer W, Ellis SL. GLP-1 receptor agonists: a review of head-to-head clinical studies. Ther Adv Endocrinol Metab. 2015;6(1):19-28.

112. Robinson LE, Holt TA, Rees K, Randeva HS, O'Hare JP. Effects of exenatide and liraglutide on heart rate, blood pressure and body weight: systematic review and meta-analysis. BMJ Open. 2013;3(1):e001986.

113. Bhandari M, Mathur W, Kumar R, Mishra A, Bhandari M. Surgical and advanced medical therapy for the treatment of type 2 diabetes in class I obese patients: a short-term outcome. Obes Surg. 2017;27(12):3267-72.

114. Sun F, Wu S, Guo S, et al. Effect of GLP-1 receptor agonists on waist circumference among type 2 diabetes patients: a systematic review and network meta-analysis. Endocrine. 2015;48(3):794-803.

115. Trautmann ME, Van GL, Han J, Hardy E. Three-year efficacy and safety of exenatide once weekly: a pooled analysis of three trials. J Diabetes Complicat. 2017;31(9):1415-22.

116. Sun F, Wu S, Wang J, et al. Effect of glucagon-like peptide-1 receptor agonists on lipid profiles among type 2 diabetes: a systematic review and network meta-analysis. Clin Ther. 2015;37(1):225-41.

117. Olmo-Garcia MI, Merino-Torres JF. GLP-1 receptor agonists and cardiovascular disease in patients with type 2 diabetes. J Diabetes Res. 2018;2(2018):1-12.

118. Giorgino F, Benroubi M, Sun JH, Zimmermann AG, Pechtner V. Efficacy and safety of once-weekly dulaglutide versus insulin glargine in patients with type 2 diabetes on metformin and glimepiride (AWARD-2). Diabetes Care. 2015;38(12):2241-9.

119. Umpierrez G, Tofe PS, Perez MF, Shurzinske L, Pechtner V. Efficacy and safety of dulaglutide monotherapy versus metformin in type 2 diabetes in a randomized controlled trial (AWARD-3). Diabetes Care. 2014;37(8):2168-76. 
120. Skrivanek Z, Gaydos BL, Chien JY, et al. Dose-finding results in an adaptive, seamless, randomized trial of once-weekly dulaglutide combined with metformin in type 2 diabetes patients (AWARD-5). Diabetes Obes Metab. 2014;16(8):748-56.

121. Ferdinand KC, White WB, Calhoun DA, et al. Effects of the once-weekly glucagon-like peptide-1 receptor agonist dulaglutide on ambulatory blood pressure and heart rate in patients with type 2 diabetes mellitus. Hypertension. 2014;64(4):731-7.

122. Wang B, Zhong J, Lin $\mathrm{H}$, et al. Blood pressure-lowering effects of GLP-1 receptor agonists exenatide and liraglutide: a meta-analysis of clinical trials. Diabetes Obes Metab. 2013;15(8):737-49.

123. Baretic M, Renar P, Aganovic I. Association of blood pressure and body weight decline during one-year treatment with the incretin analogue exenatide. Diabetol Croat. 2013;42(3):67-71.

124. Moretto TJ, Milton DR, Ridge TD, et al. Efficacy and tolerability of exenatide monotherapy over 24 weeks in antidiabetic drug-naive patients with type 2 diabetes: a randomized, double-blind, placebo-controlled, parallel-group study. Clin Ther. 2008;30(8):1448-60.

125. Sun F, Wu S, Guo S, et al. Impact of GLP-1 receptor agonists on blood pressure, heart rate and hypertension among patients with type 2 diabetes: a systematic review and network meta-analysis. Diabetes Res Clin Pract. 2015;110(1):26-37.

126. Bailey TS, Takacs R, Tinahones FJ, et al. Efficacy and safety of switching from sitagliptin to liraglutide in subjects with type 2 diabetes (LIRA-SWITCH): a randomized, double-blind, double-dummy, activecontrolled 26-week trial. Diabetes Obes Metab. 2016;18(12):1191-8.

127. Kesavadev J, Shankar A, Gopalakrishnan G, Jothydev S. Efficacy and safety of liraglutide therapy in 195 Indian patients with type 2 diabetes in real world setting. Diabetes Metab Syndr. 2015;9(1):30-3.

128. Wangnoo SK, Kumar S, Bhattacharyya A, et al. Liraglutide effect and action in diabetes-In (LEADIn): a prospective observational study assessing safety and effectiveness of liraglutide in patients with type 2 diabetes mellitus treated under routine clinical practice conditions in India. Indian $\mathrm{J}$ Endocrinol Metab. 2016;20(6):838-45.

129. Fonseca VA, DeVries JH, Henry RR, Donsmark M, Thomsen HF, Plutzky J. Reductions in systolic blood pressure with liraglutide in patients with type 2 diabetes: insights from a patient-level pooled analysis of six randomized clinical trials. J Diabetes Complicat. 2014;28(3):399-405.
130. Ahmann A, Rodbard HW, Rosenstock J, et al. Efficacy and safety of liraglutide versus placebo added to basal insulin analogues (with or without metformin) in patients with type 2 diabetes: a randomized, placebo-controlled trial. Diabetes Obes Metab. 2015;17(11):1056-64.

131. Azar ST, Echtay A, Wan Bebakar WM, et al. Efficacy and safety of liraglutide compared to sulphonylurea during Ramadan in patients with type 2 diabetes (LIRA-Ramadan): a randomized trial. Diabetes Obes Metab. 2016;18(10):1025-33.

132. Yang W, Chen L, Ji Q, et al. Liraglutide provides similar glycaemic control as glimepiride (both in combination with metformin) and reduces body weight and systolic blood pressure in Asian population with type 2 diabetes from China, South Korea and India: a 16-week, randomized, double-blind, active control trial. Diabetes Obes Metab. 2011;13(1):81-8.

133. Pfeffer MA, Claggett B, Diaz R, et al. Lixisenatide in patients with type 2 diabetes and acute coronary syndrome. N Engl J Med. 2015;373(23):2247-57.

134. Tonneijck L, Muskiet MHA, Twisk JW, et al. Lixisenatide versus insulin glulisine on fasting and postbreakfast systemic hemodynamics in type 2 diabetes mellitus patients. Hypertension. 2018;72(2):314-22.

135. Meier JJ, Rosenstock J, Hincelin-Mery A, et al. Contrasting effects of lixisenatide and liraglutide on postprandial glycemic control, gastric emptying, and safety parameters in patients with type 2 diabetes on optimized insulin glargine with or without metformin: a randomized, open-label trial. Diabetes Care. 2015;38(7):1263-73.

136. Andreadis $\mathrm{P}$, Karagiannis T, Malandris $\mathrm{K}$, et al. Semaglutide for type 2 diabetes mellitus: a systematic review and meta-analysis. Diabetes Obes Metab. 2018;20(9):2255-63.

137. Ahren B, Masmiquel L, Kumar H, et al. Efficacy and safety of once-weekly semaglutide versus once-daily sitagliptin as an add-on to metformin, thiazolidinediones, or both, in patients with type 2 diabetes (SUSTAIN 2): a 56-week, double-blind, phase 3a, randomised trial. Lancet Diabetes Endocrinol. 2017;5(5):341-54.

138. Pratley RE, Aroda VR, Lingvay I, et al. Semaglutide versus dulaglutide once weekly in patients with type 2 diabetes (SUSTAIN 7): a randomised, openlabel, phase $3 \mathrm{~b}$ trial. Lancet Diabetes Endocrinol. 2018;6(4):275-86.

139. Boyle JG, Livingstone R, Petrie JR. Cardiovascular benefits of GLP-1 agonists in type 2 diabetes: a 
comparative review. Clin Sci (Lond). 2018;132(15):1699-709.

140. Ferdinand KC, Mahata I. Cardiovascular outcome studies with glucagon-like peptide 1 receptor agonists- what will REWIND add? Ann Transl Med. 2017;5(23):476.

141. Hernandez AF, Green JB, Janmohamed S, et al. Albiglutide and cardiovascular outcomes in patients with type 2 diabetes and cardiovascular disease (Harmony Outcomes): a double-blind, randomised placebo-controlled trial. Lancet. 2018;392(10157):1519-29.

142. Green JB, Hernandez AF, D'Agostino RB, et al. Harmony Outcomes: a randomized, double-blind, placebo-controlled trial of the effect of albiglutide on major cardiovascular events in patients with type 2 diabetes mellitus- rationale, design, and baseline characteristics. Am Heart J. 2018;203:30-8.

143. Ferdinand KC, Botros FT, Atisso CM, Sager PT. Cardiovascular safety for once-weekly dulaglutide in type 2 diabetes: a pre-specified meta-analysis of prospectively adjudicated cardiovascular events. Cardiovasc Diabetol. 2016;24(15):38.

144. Ratner R, Han J, Nicewarner D, Yushmanova I, Hoogwerf BJ, Shen L. Cardiovascular safety of exenatide BID: an integrated analysis from controlled clinical trials in participants with type 2 diabetes. Cardiovasc Diabetol. 2011;16(10):22.

145. Bethel MA, Patel RA, Merrill P, et al. Cardiovascular outcomes with glucagon-like peptide-1 receptor agonists in patients with type 2 diabetes: a metaanalysis. Lancet Diabetes Endocrinol. 2018;6(2):105-13.

146. Andrikou E, Tsioufis C, Andrikou I, Leontsinis I, Tousoulis D, Papanas N. GLP-1 receptor agonists and cardiovascular outcome trials: an update. Hellenic J Cardiol. 2018. https://doi.org/10.1016/j.hjc. 2018.11.008.

147. PRNewswire. Trulicity ${ }^{\circledR}$ (dulaglutide) demonstrates superiority in reduction of cardiovascular events for broad range of people with type 2 diabetes. 5 November 2018. https://www.prnewswire.com/ news-releases/trulicity-dulaglutide-demonstratessuperiority-in-reduction-of-cardiovascular-eventsfor-broad-range-of-people-with-type-2-diabetes-300 743485.html. Accessed 1 Feb 2019.

148. Gerstein HC, Colhoun HM, Dagenais GR, et al. Design and baseline characteristics of participants in the researching cardiovascular events with a weekly incretin in diabetes (REWIND) trial on the cardiovascular effects of dulaglutide. Diabetes Obes Metab. 2018;20(1):42-9.
149. Thomas MC. The potential and pitfalls of GLP-1 receptor agonists for renal protection in type 2 diabetes. Diabetes Metab. 2017;43(Suppl 1):2S20-7.

150. Tuttle KR, Lakshmanan MC, Rayner B, et al. Dulaglutide versus insulin glargine in patients with type 2 diabetes and moderate-to-severe chronic kidney disease (AWARD-7): a multicentre, open-label, randomised trial. Lancet Diabetes Endocrinol. 2018;6(8):605-17.

151. Tuttle KR, McKinney TD, Davidson JA, Anglin G, Harper KD, Botros FT. Effects of once-weekly dulaglutide on kidney function in patients with type 2 diabetes in phase II and III clinical trials. Diabetes Obes Metab. 2017;19(3):436-41.

152. Linnebjerg H, Kothare PA, Park S, et al. Effect of renal impairment on the pharmacokinetics of exenatide. Br J Clin Pharmacol. 2007;64(3):317-27.

153. Loughlin AM, Qiao Q, Nunes AP, et al. Effectiveness and tolerability of therapy with exenatide once weekly vs basal insulin among injectable-drug-naive elderly or renal impaired patients with type 2 diabetes in the United States. Diabetes Obes Metab. 2018;20(4):898-909.

154. Marso SP, Daniels GH, Brown-Frandsen K, et al. Liraglutide and cardiovascular outcomes in type 2 diabetes. N Engl J Med. 2016;375(4):311-22.

155. León Jiménez D, Cherney DZ, Bjornstad P, Guerra LC, Miramontes González JP. Antihyperglycemic agents as novel natriuretic therapies in diabetic kidney disease. Am J Physiol Renal Physiol. 2018;315(5):F1406-15.

156. Davies MJ, Bain SC, Atkin SL, et al. Efficacy and safety of liraglutide versus placebo as add-on to glucose-lowering therapy in patients with type 2 diabetes and moderate renal impairment (LIRARENAL): a randomized clinical trial. Diabetes Care. 2016;39(2):222-30.

157. Idorn T, Knop FK, Jorgensen MB, et al. Safety and efficacy of liraglutide in patients with type 2 diabetes and end-stage renal disease: an investigatorinitiated, placebo-controlled, double-blind, parallelgroup, randomized trial. Diabetes Care. 2016;39(2):206-13.

158. Tonneijck L, Muskiet MHA, Smits MM, et al. Postprandial renal haemodynamic effect of lixisenatide vs once-daily insulin-glulisine in patients with type 2 diabetes on insulin-glargine: an 8-week, randomised, open-label trial. Diabetes Obes Metab. 2017;19(12):1669-80.

159. Hanefeld M, Arteaga JM, Leiter LA, et al. Efficacy and safety of lixisenatide in patients with type 2 
diabetes and renal impairment. Diabetes Obes Metab. 2017;19(11):1594-601.

160. Marso SP, Bain SC, Consoli A, et al. Semaglutide and cardiovascular outcomes in patients with type 2 diabetes. N Engl J Med. 2016;375(19):1834-44.

161. Marbury TC, Flint A, Jacobsen JB, Derving KJ, Lasseter K. Pharmacokinetics and tolerability of a single dose of semaglutide, a human glucagon-like peptide-1 analog, in subjects with and without renal impairment. Clin Pharmacokinet. 2017;56(11):1381-90.

162. Gupta NA, Kolachala VL, Jiang R, et al. The glucagon-like peptide-1 receptor agonist Exendin 4 has a protective role in ischemic injury of lean and steatotic liver by inhibiting cell death and stimulating lipolysis. Am J Pathol. 2012;181(5):1693-701.

163. Ryan D, Acosta A. GLP-1 receptor agonists: nonglycemic clinical effects in weight loss and beyond. Obesity (Silver Spring). 2015;23(6):1119-29.

164. Ding X, Saxena NK, Lin S, Gupta NA, Anania FA. Exendin-4, a glucagon-like protein-1 (GLP-1) receptor agonist, reverses hepatic steatosis in ob/ob mice. Hepatology. 2006;43(1):173-81.

165. Gupta NA, Mells J, Dunham RM, et al. Glucagonlike peptide- 1 receptor is present on human hepatocytes and has a direct role in decreasing hepatic steatosis in vitro by modulating elements of the insulin signaling pathway. Hepatology. 2010; 51(5):1584-92.

166. Sharma S, Mells JE, Fu PP, Saxena NK, Anania FA. GLP-1 analogs reduce hepatocyte steatosis and improve survival by enhancing the unfolded protein response and promoting macroautophagy. PLoS One. 2011;6(9):e25269.

167. Wang XC, Gusdon AM, Liu H, Qu S. Effects of glucagon-like peptide-1 receptor agonists on non-alcoholic fatty liver disease and inflammation. World J Gastroenterol. 2014;20(40):14821-30.

168. Dhir G, Cusi K. Glucagon like peptide-1 receptor agonists for the management of obesity and nonalcoholic fatty liver disease: a novel therapeutic option. J Investig Med. 2018;66(1):7-10.

169. Mills EP, Brown KPD, Smith JD, Vang PW, Trotta K. Treating nonalcoholic fatty liver disease in patients with type 2 diabetes mellitus: a review of efficacy and safety. Ther Adv Endocrinol Metab. 2018;9(1):15-28.

170. Flint A, Nazzal K, Jagielski P, Hindsberger C, Zdravkovic M. Influence of hepatic impairment on pharmacokinetics of the human GLP-1 analogue, liraglutide. Br J Clin Pharmacol. 2010;70(6):807-14.
171. Seko Y, Sumida Y, Tanaka S, et al. Effect of 12-week dulaglutide therapy in Japanese patients with biopsy-proven non-alcoholic fatty liver disease and type 2 diabetes mellitus. Hepatol Res. 2017; 47(11):1206-11.

172. Shao N, Kuang HY, Hao M, Gao XY, Lin WJ, Zou W. Benefits of exenatide on obesity and non-alcoholic fatty liver disease with elevated liver enzymes in patients with type 2 diabetes. Diabetes Metab Res Rev. 2014;30(6):521-9.

173. Bergenstal RM, Li Y, Porter TK, Weaver C, Han J. Exenatide once weekly improved glycaemic control, cardiometabolic risk factors and a composite index of an $\mathrm{HbA} 1 \mathrm{c}<7 \%$, without weight gain or hypoglycaemia, over 52 weeks. Diabetes Obes Metab. 2013;15(3):264-71.

174. Armstrong MJ, Gaunt P, Aithal GP, et al. Liraglutide safety and efficacy in patients with non-alcoholic steatohepatitis (LEAN): a multicentre, double-blind, randomised, placebo-controlled phase 2 study. Lancet. 2016;387(10019):679-90.

175. Gluud LL, Knop FK, Vilsboll T. Effects of lixisenatide on elevated liver transaminases: systematic review with individual patient data meta-analysis of randomised controlled trials on patients with type 2 diabetes. BMJ Open. 2014;4(12):e005325.

176. Carbone LJ, Angus PW, Yeomans ND. Incretinbased therapies for the treatment of non-alcoholic fatty liver disease: a systematic review and metaanalysis. J Gastroenterol Hepatol. 2016;31(1):23-31.

177. Cuthbertson DJ, Irwin A, Gardner CJ, et al. Improved glycaemia correlates with liver fat reduction in obese, type 2 diabetes, patients given glucagon-like peptide-1 (GLP-1) receptor agonists. PLoS One. 2012;7(12):e50117.

178. Prasad-Reddy L, Isaacs D. A clinical review of GLP-1 receptor agonists: efficacy and safety in diabetes and beyond. Drugs Context. 2015;4:212283.

179. Storgaard H, Cold F, Gluud LL, Vilsboll T, Knop FK. Glucagon-like peptide- 1 receptor agonists and risk of acute pancreatitis in patients with type 2 diabetes. Diabetes Obes Metab. 2017;19(6):906-8.

180. Nauck MA, Frossard JL, Barkin JS, et al. Assessment of pancreas safety in the development program of once-weekly GLP-1 receptor agonist dulaglutide. Diabetes Care. 2017;40(5):647-54.

181. Jensen TM, Saha K, Steinberg WM. Is there a link between liraglutide and pancreatitis? A post hoc review of pooled and patient-level data from completed liraglutide type 2 diabetes clinical trials. Diabetes Care. 2015;38(6):1058-66. 
182. Steinberg WM, Rosenstock J, Wadden TA, Donsmark M, Jensen CB, DeVries JH. Impact of liraglutide on amylase, lipase, and acute pancreatitis in participants with overweight/obesity and normoglycemia, prediabetes, or type 2 diabetes: secondary analyses of pooled data from the SCALE clinical development program. Diabetes Care. 2017;40(7):839-48.

183. Monami M, Nreu B, Scatena A, et al. Safety issues with glucagon-like peptide-1 receptor agonists (pancreatitis, pancreatic cancer and cholelithiasis): data from randomized controlled trials. Diabetes Obes Metab. 2017;19(9):1233-41.

184. Diabetes mellitus: a major risk factor for cardiovascular disease. A joint editorial statement by the American Diabetes Association; the National Heart, Lung, and Blood Institute; the Juvenile Diabetes Foundation International; the National Institute of Diabetes and Digestive and Kidney Diseases; and the American Heart Association. Circulation. 1999;100(10):1132-3.

185. Karla S. Diabetes in special situations: glucagon-like peptide- 1 receptor agonist use in acute myocardial infarction. Medicine Matters diabetes. 2017; 23 Oct 2017

186. Trulicity (dulaglutide): Summary of product characteristics. https://www.medicines.org.uk/emc/ medicine/29747. Accessed 5 Oct 2018.

187. Byetta (exenatide): Summary of product characteristics. https://www.medicines.org.uk/emc/ medicine/19257. Accessed 5 Oct 2018.

188. Bydureon (exenatide): Summary of product characteristics. https://www.medicines.org.uk/emc/ product/3650. Accessed 5 Oct 2018.

189. Victoza (Liraglutide): Summary of product characteristics. https://www.medicines.org.uk/emc/ medicine/21986. Accessed 5 Oct 2018.

190. Lyxumia (lixisenatide): Summary of product characteristics. https://www.medicines.org.uk/emc/ medicine/27405. Accessed 5 Oct 2018.

191. European Medicines Agency. Ozempic (semaglutide) injection, for subcutaneous use: Highlights of prescribing information, 4190425. December 2017. https://www.ema.europa.eu/documents/productinformation/ozempic-epar-product-information en.pdf. Accessed 5 Oct 2018.

192. Scheen AJ. Pharmacokinetics in patients with chronic liver disease and hepatic safety of incretinbased therapies for the management of type 2 diabetes mellitus. Clin Pharmacokinet. 2014;53(9): 773-85.
193. Gangopadhyay KK, Singh P. Consensus statement on dose modifications of antidiabetic agents in patients with hepatic impairment. Indian J Endocrinol Metab. 2017;21(2):341-54.

194. Du YF, Ou HY, Beverly EA, Chiu CJ. Achieving glycemic control in elderly patients with type 2 diabetes: a critical comparison of current options. Clin Interv Aging. 2014;9:1963-80.

195. Boustani MA, Pittman I, Yu M, Thieu VT, Varnado OJ, Juneja R. Similar efficacy and safety of onceweekly dulaglutide in patients with type 2 diabetes aged $\geq 65$ and $<65$ years. Diabetes Obes Metab. 2016;18(8):820-8.

196. Pencek R, Blickensderfer A, Li Y, Brunell SC, Anderson PW. Exenatide twice daily: analysis of effectiveness and safety data stratified by age, sex, race, duration of diabetes, and body mass index. Postgrad Med. 2012;124(4):21-32.

197. Pencek R, Blickensderfer A, Li Y, Brunell SC, Chen S. Exenatide once weekly for the treatment of type 2 diabetes: effectiveness and tolerability in patient subpopulations. Int J Clin Pract. 2012;66(11): 1021-32.

198. Gilbert M, Bain S, Franek E, Jodar-Gimeno E, Nauck M, Pratley R. Effect of liraglutide on cardiovascular outcomes in elderly patients in the LEADER trial. JACC. 2018;71(11 Supplement):A1718.

199. Chitnis A, Ganz M, Hammer M, Langer J. Realworld clinical effectiveness of Liraglutide in individuals 65 years and older with type 2 diabetes in the United States. J Diabetes Metab. 2014;5(7): 1000403.

200. Raccah D, Miossec P, Esposito V, Niemoeller E, Cho $M$, Gerich J. Efficacy and safety of lixisenatide in elderly $(>/=65$ years old) and very elderly $(\geq 75$ years old) patients with type 2 diabetes: an analysis from the GetGoal phase III programme. Diabetes Metab Res Rev. 2015;31(2):204-11.

201. Warren M, Chaykin L, Trachtenbarg D, Nayak G, Wijayasinghe N, Cariou B. Semaglutide as a therapeutic option for elderly patients with type 2 diabetes: pooled analysis of the SUSTAIN 1-5 trials. Diabetes Obes Metab. 2018;20:2291-7.

202. Censani M, Chin VL, Fennoy I. Exenatide effects on cardiometabolic risk and weight in adolescents with morbid obesity and type 2 diabetes mellitus: two case reports. J Obes Weight Loss Medicat. 2015; 1(1):004.

203. Klein DJ, Battelino T, Chatterjee DJ, Jacobsen LV, Hale PM, Arslanian S. Liraglutide's safety, tolerability, pharmacokinetics, and pharmacodynamics in pediatric type 2 diabetes: a randomized, double- 
blind, placebo-controlled trial. Diabetes Technol Ther. 2014;16(10):679-87.

204. Zhou QX, Wang ZY, Zhao HF, Wang S. The effects of GLP-1 analogues on pre-diabetes of the children. Exp Ther Med. 2017;13(4):1426-30.

205. Blackman A, Foster GD, Zammit G, et al. Effect of liraglutide $3.0 \mathrm{mg}$ in individuals with obesity and moderate or severe obstructive sleep apnea: the SCALE Sleep Apnea randomized clinical trial. Int J Obes (Lond). 2016;40(8):1310-9.

206. Lamos EM, Malek R, Davis SN. GLP-1 receptor agonists in the treatment of polycystic ovary syndrome. Expert Rev Clin Pharmacol. 2017;10(4):401-8.

207. Shi Y, Cui Y, Sun X, et al. Hypertension in women with polycystic ovary syndrome: prevalence and associated cardiovascular risk factors. Eur J Obstet Gynecol Reprod Biol. 2014;173:66-70.

208. Orio F, Muscogiuri G, Nese C, et al. Obesity, type 2 diabetes mellitus and cardiovascular disease risk: an uptodate in the management of polycystic ovary syndrome. Eur J Obstet Gynecol Reprod Biol. 2016;207:214-9.

209. Dunaif A, Segal KR, Futterweit W, Dobrjansky A. Profound peripheral insulin resistance, independent of obesity, in polycystic ovary syndrome. Diabetes. 1989;38(9):1165-74.

210. Ehrmann DA, Barnes RB, Rosenfield RL, Cavaghan MK, Imperial J. Prevalence of impaired glucose tolerance and diabetes in women with polycystic ovary syndrome. Diabetes Care. 1999;22(1):141-6.

211. Haqq L, McFarlane J, Dieberg G, Smart N. Effect of lifestyle intervention on the reproductive endocrine profile in women with polycystic ovarian syndrome: a systematic review and meta-analysis. Endocr Connect. 2014;3(1):36-46.

212. Thomson RL, Buckley JD, Noakes M, Clifton PM, Norman RJ, Brinkworth GD. The effect of a hypocaloric diet with and without exercise training on body composition, cardiometabolic risk profile, and reproductive function in overweight and obese women with polycystic ovary syndrome. J Clin Endocrinol Metab. 2008;93(9):3373-80.

213. Chapli S, Bain S. Properties of GLP-1 agonists and their use in type 2 diabetes. Drug Points. 2016;3:43-6.

214. Kalra S. Choosing appropriate glucagon-like peptide 1 receptor agonists: a patient-centered approach. Diabetes Ther. 2014;5(1):333-40.

215. Kapitza C, Forst T, Coester HV, Poitiers F, Ruus P, Hincelin-Mery A. Pharmacodynamic characteristics of lixisenatide once daily versus liraglutide once daily in patients with type 2 diabetes insufficiently controlled on metformin. Diabetes Obes Metab. 2013;15(7):642-9.

216. Lorenz M, Pfeiffer C, Steinstrasser A, et al. Effects of lixisenatide once daily on gastric emptying in type 2 diabetes-relationship to postprandial glycemia. Regul Pept. 2013;10(185):1-8.

217. Pratley R, Nauck M, Bailey T, et al. One year of liraglutide treatment offers sustained and more effective glycaemic control and weight reduction compared with sitagliptin, both in combination with metformin, in patients with type 2 diabetes: a randomised, parallel-group, open-label trial. Int J Clin Pract. 2011;65(4):397-407.

218. Grant P, Lipscomb D, Quin J. Psychological and quality of life changes in patients using GLP-1 analogues. J Diabetes Complicat. 2011;25(4):244-6.

219. Bode BW, Testa MA, Magwire M, et al. Patient-reported outcomes following treatment with the human GLP-1 analogue liraglutide or glimepiride in monotherapy: results from a randomized controlled trial in patients with type 2 diabetes. Diabetes Obes Metab. 2010;12(7):604-12.

220. Mollema ED, Snoek FJ, Pouwer F, Heine RJ, van der Ploeg HM. Diabetes fear of injecting and self-testing questionnaire: a psychometric evaluation. Diabetes Care. 2000;23(6):765-9.

221. Szeinbach SL, Barnes JH, Summers KH, Lenox SM. Development of an instrument to assess expectations of and preference for an insulin injection pen compared with the vial and syringe. Clin Ther. 2004;26(4):590-7.

222. European Medicines Agency. Trulicity: Summary of product characteristics. 21 November 2014 .. https://www.ema.europa.eu/documents/productinformation/trulicity-epar-product-information en.pdf. Accessed 15 Oct 2018.

223. Giorgino F, Penfornis A, Pechtner V, Gentilella R, Corcos A. Adherence to antihyperglycemic medications and glucagon-like peptide 1-receptor agonists in type 2 diabetes: clinical consequences and strategies for improvement. Patient Prefer Adher. 2018;12:707-19.

224. Byetta ${ }^{\circledR}$ (Exenatide Injection): Product monograph. 2014.

225. European Medicines Agency. Bydureon: Summary of product characteristics. https://www.ema.europa. $\mathrm{eu} /$ documents/product-information/bydureon-eparproduct-information_en.pdf. Accessed 15 Oct 2018. 
226. Victoza: Summary of product characteristics. https://ec.europa.eu/health/documents/communityregister/2017/20170725138543/anx_138543_en.pdf. Accessed 15 Oct 2018.

227. European Medicines Agency. Lyxumia: Summary of product characteristics. 2013. https://www.ema. europa.eu/documents/product-information/lyxumiaepar-product-information_en.pdf. Accessed 15 Oct 2018.

228. Moreira RO, Cobas R, Lopes Assis Coelho RC. Combination of basal insulin and GLP-1 receptor agonist: Is this the end of basal insulin alone in the treatment of type 2 diabetes? Diabetol Metab Syndr. 2018;10:26.

229. Nauck M, Wilhelm B. Why is a combination of basal insulin with a GLP-1 receptor agonist useful in many patients with type 2 diabetes? MMW Fortschr Med. 2017;159(Suppl 5):7-15.

230. Blumer I, Pettus JH, Santos CT. Fixed-ratio combination therapy for type 2 diabetes: the top ten things you should know about insulin and glucagon-like peptide-1 receptor agonist combinations. Postgrad Med. 2018;130(4):375-80.

231. Xultophy ${ }^{\circledR} 100 / 3.6$ (insulin degludec and liraglutide injection): Prescribing information. 2016. https://www.novo-pi.com/xultophy10036. pdf. Accessed 5 Oct 2018.

232. Gough SC, Bode B, Woo V, et al. Efficacy and safety of a fixed-ratio combination of insulin degludec and liraglutide (IDegLira) compared with its components given alone: results of a phase 3 , open-label, randomised, 26-week, treat-to-target trial in insulinnaive patients with type 2 diabetes. Lancet Diabetes Endocrinol. 2014;2(11):885-93.

233. Buse JB, Vilsboll T, Thurman J, et al. Contribution of liraglutide in the fixed-ratio combination of insulin degludec and liraglutide (IDegLira). Diabetes Care. 2014;37(11):2926-33.

234. Lingvay I, Perez MF, Garcia-Hernandez P, et al. Effect of insulin glargine up-titration vs insulin degludec/Liraglutide on glycated hemoglobin levels in patients with uncontrolled type 2 diabetes: the DUAL V randomized clinical trial. JAMA. 2016;315(9):898-907.

235. Soliqua ${ }^{\circledR} 100 / 33$ (insulin glargine and lixisenatide injection): Prescribing information. 2017. https:// www.accessdata.fda.gov/drugsatfda_docs/label/2017/ 208673s002lbl.pdf. Accessed 5 Oct 2018.

236. Rosenstock J, Aronson R, Grunberger G, et al. Benefits of lixilan, a titratable fixed-ratio combination of insulin glargine plus lixisenatide, versus insulin glargine and lixisenatide monocomponents in type
2 diabetes inadequately controlled on oral agents: the LixiLan-O randomized trial. Diabetes Care. 2016;39(11):2026-35.

237. Matza LS, Boye KS, Currie BM, et al. Patient perceptions of injection devices used with dulaglutide and liraglutide for treatment of type 2 diabetes. Curr Med Res Opin. 2018;34(8):1457-64.

238. Matfin G, Van BK, Zimmermann AG, Threlkeld R, Ignaut DA. Safe and effective use of the once weekly dulaglutide single-dose pen in injection-naive patients with type 2 diabetes. J Diabetes Sci Technol. 2015;9(5):1071-9.

239. Reaney M, Yu M, Lakshmanan M, Pechtner V, van Brunt K. Treatment satisfaction in people with type 2 diabetes mellitus treated with once-weekly dulaglutide: data from the AWARD-1 and AWARD-3 clinical trials. Diabetes Obes Metab. 2015;17(9):896-903.

240. Dharmalingam M. Efficacy and tolerability of GLP-1 agonists in patients with type 2 diabetes mellitus: an Indian perspective. Ther Adv Endocrinol Metab. 2014;5(6):159-65.

241. Kalra S. Glucagon-like peptide-1 receptors agonists (GLP1 RA). J Pak Med Assoc. 2013;63(10):1312-5.

242. Sun F, Chai S, Yu K, et al. Gastrointestinal adverse events of glucagon-like peptide-1 receptor agonists in patients with type 2 diabetes: a systematic review and network meta-analysis. Diabetes Technol Ther. 2015;17(1):35-42.

243. Kaur P, Mahendru S, Mithal A. Long-term efficacy of liraglutide in Indian patients with type 2 diabetes in a real-world setting. Indian $\mathrm{J}$ Endocrinol Metab. 2016;20(5):595-9.

244. Bawa T, Dhingra V, Malhotra N, Wasir JS, Mithal A. Clinical experience with exenatide in obese North Indian patients with type 2 diabetes mellitus. Indian J Endocrinol Metab. 2013;17(1):91-4.

245. Horowitz M, Aroda VR, Han J, Hardy E, Rayner CK. Upper and/or lower gastrointestinal adverse events with glucagon-like peptide-1 receptor agonists: incidence and consequences. Diabetes Obes Metab. 2017;19(5):672-81.

246. Filippatos TD, Panagiotopoulou TV, Elisaf MS. Adverse effects of GLP-1 receptor agonists. Rev Diabetes Stud. 2014;11(3-4):202-30.

247. Li L, Shen J, Bala MM, et al. Incretin treatment and risk of pancreatitis in patients with type 2 diabetes mellitus: systematic review and meta-analysis of randomised and non-randomised studies. BMJ. 2014;15(348):g2366. 